\begin{abstract}
UNIVERSIDADE DE SÃO PAULO
ESCOLA DE ENFERMAGEM DE RIBEIRÃO PRETO PROGRAMA DE PÓS-GRADUAÇÃO EM ENFERMAGEM PSIQUIÁTRICA
\end{abstract}

RESGATANDO CONFLITOS RELATIVOS À SEXUALIDADE DOS CLIENTES PORTADORES DE CORONARIOPATIAS

Sílvia Sidnéia da Silva

Ribeirão Preto

2007 
UNIVERSIDADE DE SÃO PAULO

ESCOLA DE ENFERMAGEM DE RIBEIRÃO PRETO

\title{
RESGATANDO CONFLITOS RELATIVOS À SEXUALIDADE DOS CLIENTES PORTADORES DE CORONARIOPATIAS
}

\begin{abstract}
Sílvia SIDNÉIA DA SILVA
Tese apresentada ao Programa de PósGraduação em Enfermagem Psiquiátrica da Escola de Enfermagem da Universidade de São Paulo - USP, para obtenção do título de Doutor em Enfermagem Psiquiátrica.

Área de Concentração: Enfermagem Psiquiátrica.

Linha de Pesquisa: Educação em Saúde e

Formação de Recursos Humanos
\end{abstract}

Orientadora

PROF ${ }^{a}$ DR $^{\mathrm{a}}$ SÔNIA MARIA V. BUENO

\section{Ribeirão Preto}


AUTORIZO A REPRODUÇÃO E DIVULGAÇÃO TOTAL OU PARCIAL DESTE TRABALHO, POR QUALQUER MEIO CONVENCIONAL OU ELETRÔNICO, PARA FINS DE ESTUDO E PESQUISA, DESDE QUE CITADA A FONTE.

\section{FICHA CATALOGRÁFICA}

Silva, Silvia Sidnéia da

Resgatando conflitos relativos à sexualidade dos clientes portadores de coronariopatias, 2007.

151 p.: il. ; $30 \mathrm{~cm}$

Tese de Doutorado, apresentada à Escola de Enfermagem de Ribeirão Preto/USP - Área de concentração: Enfermagem Psiquiátrica.

Orientadora: Bueno, Sonia Maria Villela.

1. Sexualidade. 2. Coronariopatia. 3. Educação em Saúde. 4. Enfermagem. 


\section{FOLHA DE APROVAÇÃO}

Silvia Sidnéia da Silva

Resgatando conflitos relativos à sexualidade dos portadores de coronariopatias

Aprovado em:

Tese apresentada à Escola de Enfermagem de Ribeirão Preto da Universidade de São Paulo para obtenção do título de Doutor.

Área de Concentração: Enfermagem Psiquiátrica.

Banca Examinadora

Prof. Dr.

Instituição:

Assinatura:

Prof. Dr.

Instituição: Assinatura:

Prof. Dr.

Instituição: Assinatura:

Prof. Dr.

Instituição: Assinatura:

Prof. Dr.

Instituição: Assinatura: 
"O que vale na vida não é o ponto de partida e sim a caminhada. Caminhando e semeando, no fim terás o que colher" 
(CoraCoralina) 
A Deus,

por ter me oferecido a vida e com ela a coragem, o amor, a sabedoria, a humildade, o respeito; meus pais, meus irmãos, meus sobrinhos, meus mestres, meus amigos, meus alunos e meus clientes. Pessoas e sentimentos tão importantes, que em qualquer 


\section{momento, me fazem viver, refletir e buscar ser melhor para merecê-los.}




\section{DEDICATÓRIA}

\begin{tabular}{lrr}
\multicolumn{1}{c}{ Aos } & meus & pais, \\
Sebastião e & Maria r & (in \\
memorian), pelos & inúmeros \\
esforços doados para & meu \\
crescimento & pessoal & e \\
profissional, em & detrimento, \\
muitas vezes, & de & suas \\
necessidades! & Vocês & me \\
educaram para uma vida! & Me \\
orgulho por estar com & vocês \\
nessa existência. Minha eterna \\
gratidão.
\end{tabular}

Meus irmãos, Wilson e Márcia, por estarem comigo em todas as caminhadas; incentivando, compartilhando e valorizando cada ato de esforço e conquista. Meu muito obrigada!

Ao meu cunhado Adriano, meus sobrinhos Henrique e Fernando, por fazerem parte de minha vida, dividindo todas as dificuldades e compartilhando os desafios. Obrigada pela confiança e pela disponibilidade em ajudar! 
Ao Edílson, namorado, amigo e companheiro de todas as horas, nesta trajetória em busca de meus sonhos. Obrigada por tudo! 


\section{AGRADECIMENTOS ESPECIAIS}

A Prof ${ }^{a}$ Dra. Sonia Maria Villela Bueno, você é estímulo nos momentos de desalento, forças onde - desfalecimento se instala, luz onde já se percebe a escuridão, calma onde a agitação se anuncia...você tem sabedoria para muitas existências! Você é especial! Obrigada por dividir e doar momentos desta sua vida e muito deste seu saber.

Aos professores Doutores Manoel Antonio dos Santos, Edson Garcia Soares, Denize Boutellet Munari e Sebastiana Aparecida Diniz, que avaliaram este trabalho e contribuíram com muito carinho, rigor e profissionalismo para seu enriquecimento. Obrigada pelo compartilhar e pela doação de seus saberes.

Helena Pessini ${ }^{A}$ Prof $^{a}$ Dra. Maria acreditar em meu potencial e oferecer a possibilidade de mostrar meu trabalho, apoiando sempre meu sonho de docência. Aos amigos da Unaerp: Duda, Tati, Cléber,Juliana, Eliana, Ricardo, Cris,Cássia, Edna, Marcelo e Maria Helena pelo apoio constante e incentivo em momentos tão tensos e trabalhosos. Obrigada por dividirem seus cotidianos comigo e me incentivar sempre. Vocês são essenciais para minha vida.

Aos amigos da Escola de Enfermagem-Usp Ribeirão Preto: Dri Borela, Cidinha, Osmarina, Lurdes, Bernadete, Fran Kethlein e Rosana, pela paciência e carinho prestados durante todo o período de realização deste Doutorado. 
Aos amigos de Brodowski: Dona Eunice, José Fabbri, funcionárias do Cartório de Regitrocível, Dola, Antonieta, Silvia, Juliana, Nildinha e Zoca, sem vocês não conseguiria realizar este trabalho! Aos meus alunos, que me apresentam desafios diários e constantes, num convite contínuo de crescimento e descobertas.

Aos meus clientes e

familiares, que me receberam em suas casas, me acolhendo com respeito e significância, possibilitando a concretização deste estudo. Obrigada pela amizade.

A todos que de forma direta e indiretamente contribuíram para a realização deste estudo. Muito obrigada! 


\section{SUMÁRIO}

\section{Lista de abreviaturas e siglas}

\section{Lista de tabelas}

\section{Resumo}

\section{Abstract \\ Resumen}

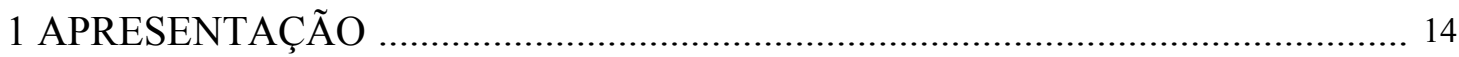

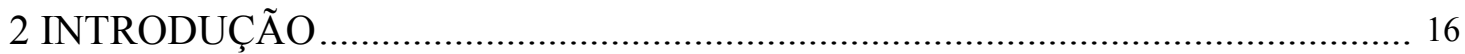

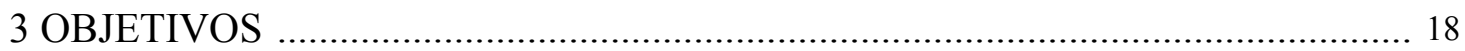

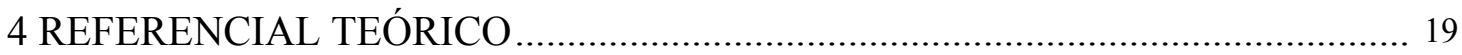

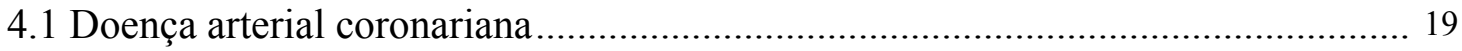

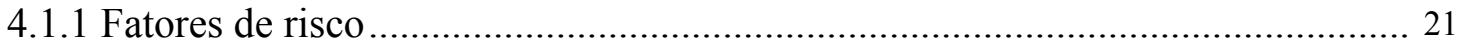

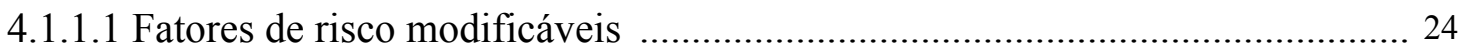

4.1.1.2 Fatores de risco não modificáveis …......................................................... 27

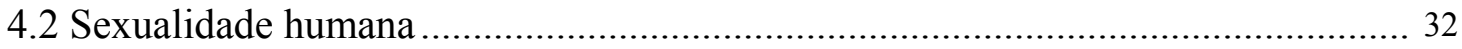

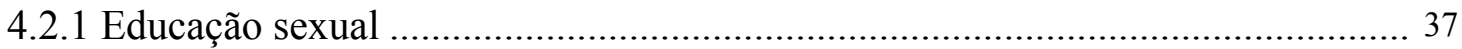

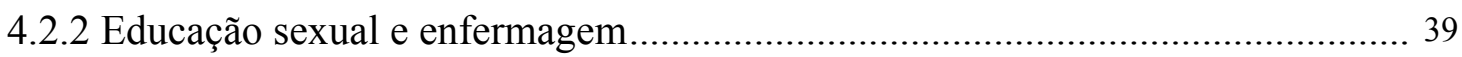

5 REFERENCIAL TEÓRICO-METODOLÓGICO................................................ 44

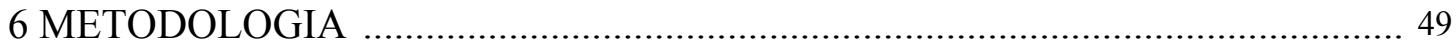

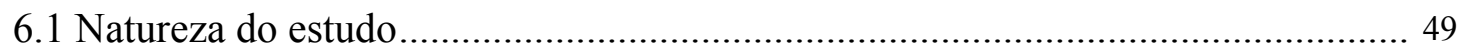

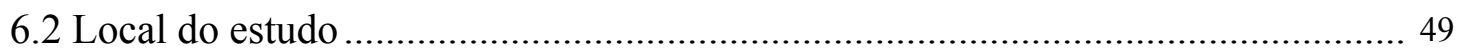

6.3 População e amostra do estudo ............................................................................. 50

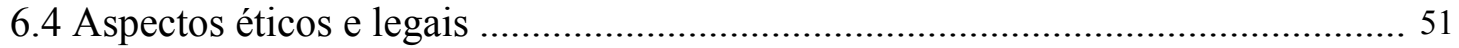

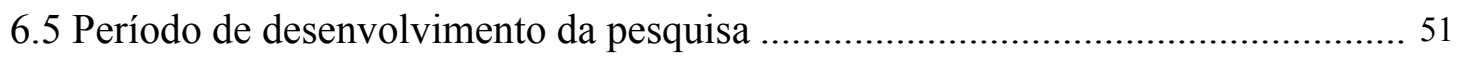

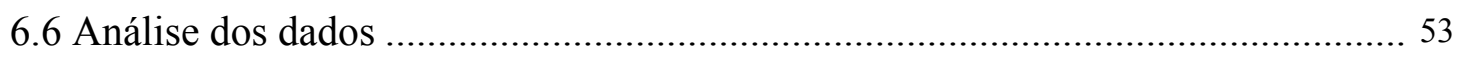

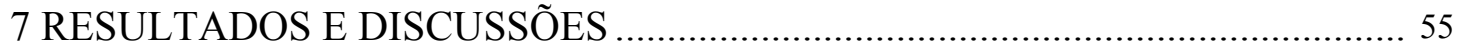

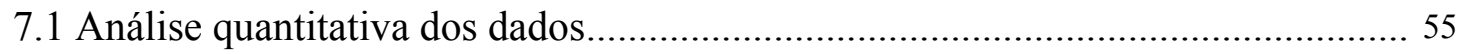

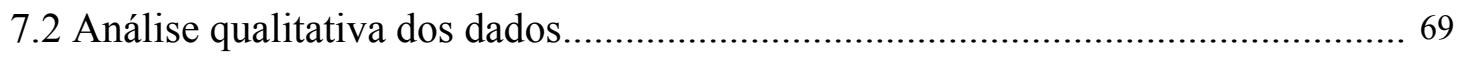

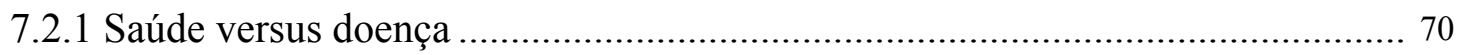

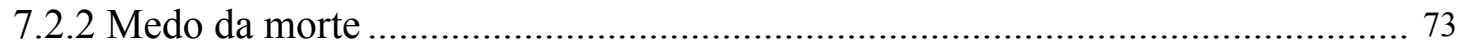

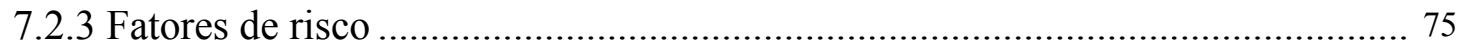




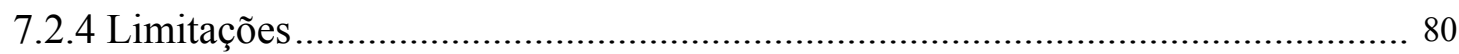

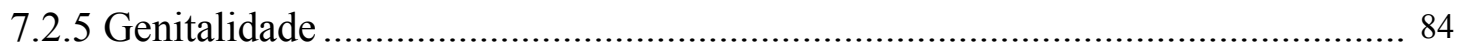

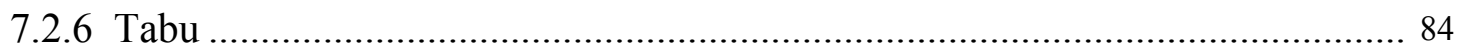

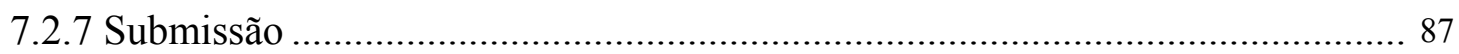

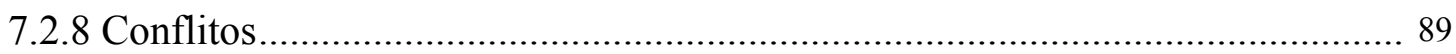

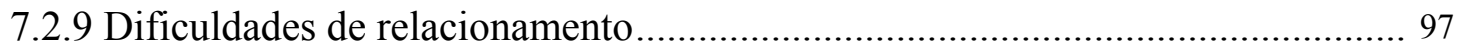

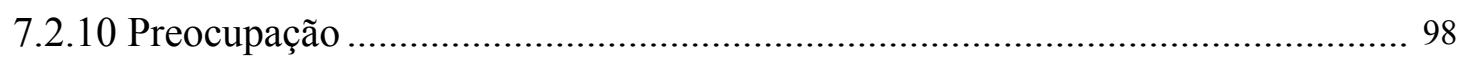

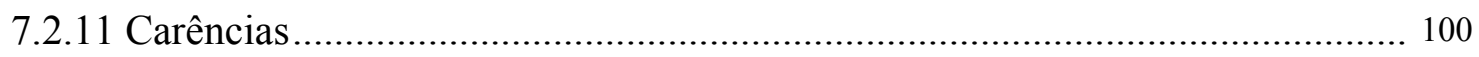

8 DESENVOLVIMENTO DA AÇÃO EDUCATIVA............................................. 103

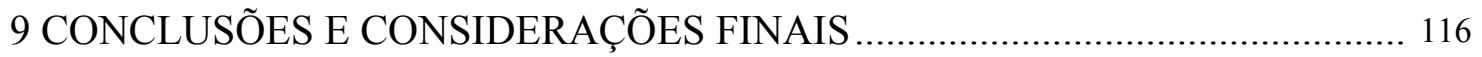

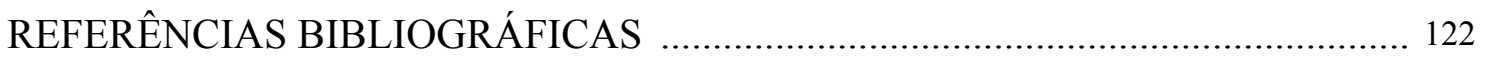

APÊNDICE A - Questionário Informativo ........................................................ 145

APÊNDICE B - Ofício Prefeito Municipal Brodowski .............................................. 147

APÊNDICE C - Ofício Secretaria Municipal de Saúde Brodowski ........................... 148

APÊNDICE D - Ofício ao Comitê de Ética em Pesquisa com Seres Humanos ......... 149

APÊNDICE E - Termo de Consentimento Livre e Esclarecido .................................. 150

ANEXO 1 - Aprovação do Comitê de Ética em Pesquisa com Seres Humanos .......... 151 
LISTA DE ABREVIATURAS E SIGLAS

\begin{tabular}{ll} 
AP & - Angina Pectoris \\
AVC & - Acidente Vascular Cerebral \\
DAC & - Doença Arterial Coronariana \\
DCV & - Doenças cardiovasculares \\
DM & - Diabetes Mellitus \\
EUA & - Estados Unidos da América \\
Fem. & - Feminino \\
HAS & - Hipertensão Arterial Sistêmica \\
HDL & - Lipoproteína de alta densidade \\
IAM & - Infarto Agudo do Miocárdio \\
IMC & - Índice de Massa Corporal \\
Kg/m & - Quilogramas por metro quadrado \\
LDL & - Lipoproteína de baixa densidade \\
Masc. & - Masculino \\
mg/dl & - miligrama por decilitro \\
OMS & Organização Mundial de Saúde \\
\hline &
\end{tabular}




\section{LISTA DE TABELAS}

TABELA 1 Distribuição de sujeitos segundo sexo e faixa etária. Ribeirão Preto, 2007

TABELA 2 Distribuição de sujeitos segundo índice de massa corporal (IMC) e sexo. Ribeirão Preto, 2007

TABELA 3 Distribuição de sujeitos segundo sexo e nível de instrução Ribeirão Preto, 2007

TABELA 4 Distribuição de sujeitos segundo sexo e a renda familiar em salários mínimos (R \$350,00). Ribeirão Preto, 2007

TABELA 5 Distribuição de sujeitos segundo sexo e fatores de risco presentes em suas vidas e referidos como possíveis causas de seu problema no coração. Ribeirão Preto, 2007

TABELA 6 Distribuição dos sujeitos segundo sexo e diagnóstico principal. Ribeirão Preto, 2007 


\section{RESUMO}

SILVA, S. S. Resgatando conflitos relativos à sexualidade dos clientes portadores de coronariopatias. Tese Doutorado - Escola de Enfermagem de Ribeirão Preto da Universidade de São Paulo.

Trata-se de um estudo descritivo, de abordagem quali-quantitativa que teve o objetivo de identificar junto aos clientes portadores de coronariopatias quais as dificuldades em relação aos fatores de risco quanto à sua doença, associando-as à sua sexualidade. O referencial teórico-metodológico utilizado foi de Freire, adaptado por Bueno. A amostra constituiu-se de 36 sujeitos, com idades entre 23 e 86 anos, de ambos os sexos, maioria casada, usuários do Sistema Único de Saúde, portadores do diagnóstico de doença arterial coronariana, residentes em Brodowski-SP. A coleta de dados ocorreu de outubro de 2006 a julho de 2007, nos domicílios dos sujeitos, utilizando a entrevista semi-estruturada. Para a análise quantitativa foram considerados dados de identificação, fatores de risco e diagnóstico principal e na análise qualitativa pautamo-nos nas questões pertinentes ao tema central, com transcrições de relatos que resultaram em categorização, extraindo onze temas geradores que possibilitaram as discussões e intervenções educativas. A coronariopatia ocorreu nos indivíduos do sexo masculino, a partir dos 23 anos, e aos 40 anos, no sexo feminino; $77,8 \%$ dos sujeitos possuíam índice de massa corpórea acima de $25 \mathrm{~kg} / \mathrm{m}^{2}$; o nível de instrução predominante foi o ensino fundamental incompleto (47,2\%); a amostra diferiu, considerando o sexo, quanto ao que consideram fator de risco para a ocorrência de sua doença no coração; houve predomínio da angina pectoris como diagnóstico principal em $61 \%$ dos sujeitos; a concepção saúde-doença explicitada nos relatos deles fundamentou-se na teoria da determinação social, com o significado da vida sendo associado à existência de saúde na família como aspecto positivo e à ocorrência de sua doença como algo negativo; exteriorizaram o medo da morte quando falaram sobre seu problema cardíaco; assinalando limitações físicas, sociais e emocionais como dificuldades após o aparecimento da doença. Os termos sexualidade e sexo foram entendidos como sinônimos, definindo-os como ato sexual e deixando claros os tabus existentes acerca das temáticas. Evidenciou-se a submissão da mulher em relação ao homem e conflitos na vida sexual após a ocorrência da patologia cardíaca, uma vez que relataram dificuldades para manter a atividade sexual, abandonando a genitalidade, em alguns casos; embora as dificuldades de relacionamento do casal já existissem antes da ocorrência do problema cardíaco. As famílias dos sujeitos manifestaram preocupações com eles após a instalação da coronariopatia, atitude entendida pelos e coletivo, as quais foram evidenciadas na intervenção educativa. Os achados do estudo ratificam a necessidade dos profissionais da saúde exercitarem novas formas de assistência à população. Neste sentido, podem participar da construção de alternativas em saúde que priorizem o cuidado integral ao ser humano.

Palavras-chave: sexualidade, coronariopatia, educação em saúde, enfermagem. 


\section{ABSTRACT}

SILVA, S. S. Revisiting sexuality conflicts of patients with pathological coronary conditions. Doctoral Dissertation - Ribeirão Preto Nursing School, University of São Paulo.

This is a quali-quantitiative, descriptive study aimed at surveying the difficulties of coronary sufferers regarding the risk factors for their conditions, and how these difficulties relate to their sexuality. Bueno's adaptation of Freire's theoretical and methodological framework has been used. The sample population was comprised of 36 male and female residents of Brodowski-SP, aged between 23 and 86 years, most of whom were married and users of the Unified Health Care System, and had been diagnosed with coronary artery disease. The data were collected between October 2006 and July 2007 in the homes of the subjects by means of a semi-structured interview. Personal information, risk factors and the main diagnosis were the object of quantitative analysis whereas the focus of qualitative analysis was on the questions related to the core theme of the study, and involved transcribing and categorizing reports, and extracting 11 generating themes that allowed for discussion and pedagogical interventions. The coronary conditions occurred in males after their 23rd year of age, and after the 40th year in females; the body mass indices for $77.8 \%$ of the sample were above $25 \mathrm{~kg} / \mathrm{m}^{2}$; the predominant instruction level among all subjects was incomplete fundamental schooling (47.2\%); the sample differed according to gender in regard to the understanding of risk factors for the manifestation of their coronary condition; angina pectoris prevailed as the main diagnosis among $61 \%$ of the subjects; the understanding of health-illness which was made explicit in the reports by subjects was grounded on the theory of social determination, with the meaning of life being associated with the existence of health in the family as a positive aspect, and the occurrence of disease being negative; the fear of death was reported when the subjects talked about their cardiac condition; identifying physical, social and emotional limitations as difficulties following the occurrence of their disease. The words sexuality and sex were perceived as synonyms by the sample, and the subjects defined them as sexual intercourse, making clear the taboos surrounding the topic; female submission to males became evident as did the conflicts in sex life following the occurrence of the pathological cardiac condition since subjects reported difficulties to sustain sexual activity, abandoning genitality in some cases; even though difficulties had affected the couple's relationship prior to the occurrence of the cardiac condition. Family members expressed their concern for the subjects after the manifestation of the coronary pathology; an attitude which was understood by them as care and, on occasion, as limitation to living; finally they referred individual and collective needs which became explicit during the educational intervention. The findings of this study confirm the need for health care professionals to exercise new forms of care to patients. In this regard, they can participate in the construction of alternative treatments that promote holistic care to human beings.

Keywords: sexuality, coronary pathologies, health education, nursing. 


\section{RESUMÉN}

SILVA, S. S. Rescatando conflictos relacionados a la sexualidad de los clientes portadores de coronariopatias. Tesis Doctorado - Escuela de Enfermeria de Ribeirão Preto de la Universidad de São Paulo.

Se trata de un estudio descriptivo, de abordaje cuali-cuantitativo que ha tenido el objetivo de averiguar con los clientes portadores de coronariopatias cuales son las dificultades relacionadas a los factores de riesgo referentes a su enfermedad, asociándolas a su sexualidad. La referencia teórico-metodológico utilizada fue de Freire, adaptado por Bueno. La muestra se constituyó de 36 individuos, con edades entre 23 y 86 años, de ambos sexos, la mayor parte casados, usuarios del Sistema Único de Salud, portadores del diagnóstico de la enfermedad arterial coronariana, domiciliados en la ciudad de Brodowski. La colecta de datos ocurrió de octubre de 2006 a julio de 2007, en los domicilios de los sujetos, utilizando la entrevista semiestructurada. Para el análisis cuantitativo han sido considerados datos de identificación, factores de riesgo y diagnóstico principal y el análisis cualitativo fue basado en cuestiones pertinentes al tema central, con transcripciones de relatos por categorización, extrayendo once temas generadores que hicieron posible las discusiones e intervenciones educativas. La coronariopatia se presentó, en individuos del sexo masculino, a partir de los 23 años y a los 40 años en el sexo femenino; $77,8 \%$ de los individuos poseían índice de masa corporal mayor que $25 \mathrm{~kg} / \mathrm{m}^{2}$; el nivel de instrucción predominante de los individuos fue el fundamental incompleto $(47,2 \%)$; la muestra fue diferente, considerando el sexo, en lo que se considera factor de riesgo para la ocurrencia de su enfermedad del corazón; hubo un predominio da angina pectoris como diagnóstico principal en $61 \%$ de los individuos; el concepto salud-enfermedad explicitada en relatos de los individuos ha sido fundamentada en la teoría de la determinación social, con el significado de la vida siendo asociado a la existencia de salud en la familia como aspecto positivo y a la ocurrencia de su enfermedad como negativo; dieron a mostrar el miedo a la muerte cuando hablaron sobre su problema cardíaco; manifestando limitaciones físicas, sociales y emocionales como dificultades después de aparecimiento de la enfermedad. Los términos sexualidad y sexo fueron entendidos como sinónimos, con la muestra definiéndolos como acto sexual y dejando claros los tabúes existentes acerca de las temáticas; se dejó evidente la sumisión de la mujer en relación al hombre y conflictos en la vida sexual después de la ocurrencia de la patología cardíaca, una vez que relataron dificultades para mantener la actividad sexual, abandonando la genitalidad, en algunos casos; mismo ya existiendo las dificultades de relacionamiento de pareja antes de la ocurrencia del problema cardíaco. Las familias de los individuos manifestaron preocupación por ellos después de la instalación de la coronariopatia, la actitud fue comprendida por los individuos como cuidado $\mathrm{y}$, a veces, como limitación para vivir; refiriéndose, por fin, a carencias en los ámbitos individual y colectivo, evidenciadas en la intervención educativa. Las investigaciones del estudio comprobaron la necesidad de que los profesionales de la salud ejerciten nuevas formas de asistir a la población. En ese sentido, pueden participar de la construcción de alternativas en el área de la salud que prioricen el cuidado integral al ser humano.

Palabras-clave: sexualidad, coronariopatia, educación en el área de la salud, enfermería. 
1 expresentacão 
Enquanto aluna de graduação do curso de Enfermagem fui abordada, naquela época, por uma colega de minha cidade que se encontrava em situação de desabafo quanto ao seu relacionamento sexual com o parceiro, vítima de evento isquêmico. Referia-se à dificuldade em retomar sua vida sexual, até então ativa, após ter sido ele acometido por um infarto agudo do miocárdio, vivendo ainda o casal em idade vivaz para o relacionamento sexual. Todavia, sentiam medo que essa prática sexual trouxesse maiores complicações no quadro cardiológico instalado.

Assim, o relato me fora confiado por acreditar que poderia ajudá-la e ao seu companheiro a encontrar caminhos para voltar a viver com qualidade, uma vez que classificavam sua sexualidade como fator de realização pessoal. Sugeri a ela que ambos procurassem o médico que os acompanhavam e que conversassem sobre essa questão.

Com o passar dos anos, já exercendo a profissão como enfermeira, me defrontava com um número crescente de clientes portadores de coronariopatias, com a doença manifestando-se de forma cada vez mais precoce. Os dados epidemiológicos descritos na literatura referentes à ocorrência das coronariopatias, considerando a idade dos indivíduos, eram diferentes daqueles que vivenciava diariamente, pois os clientes atendidos eram adultos jovens; circunstâncias que comprometiam a qualidade de vida das pessoas acometidas pela patologia supracitada, nos âmbitos pessoal e profissional.

Esta situação, fazendo parte constante do meu cotidiano profissional, me preocupava, pois indivíduos cada vez mais jovens poderiam encontrar impasses para o exercício de sua sexualidade, por acreditarem nas dificuldades do desempenho sexual, em detrimento ao processo patológico cardíaco pelos quais atravessavam, demandando orientações específicas, inclusive para essas questões. Esses fatos exigiam o envolvimento 
efetivo dos profissionais da área de saúde e justificaram, na época, os objetivos de minha dissertação de mestrado, defendida no ano de 2003. 
2 Ontroducão 
$\mathrm{Na}$ busca de identificar o perfil dos clientes portadores de coronariopatias, que reinternavam com freqüência no hospital onde trabalhávamos, nos propusemos a investigar seu estilo de vida, sua biologia humana, suas relações com o meio ambiente e com profissionais de saúde, e pudemos detectar no período de realização da dissertação de mestrado que o conhecimento daquela população estudada quanto aos fatores de risco para a doença arterial coronariana (DAC) era limitado ou nulo, acarretando sérios comprometimentos em seu ciclo vital, uma vez que a equipe multiprofissional não possuía uma relação que permitisse ouvir, esclarecer e orientar o cliente e família, após a ocorrência do evento isquêmico (SILVA, 2003).

Constatamos, a partir de nossas vivências e conclusões daquele estudo, a necessidade de compreendermos melhor as questões que atrelam à sexualidade do cliente portador de cardiopatia buscando caminhos alternativos, tendo em vista as proximidades e identificações através dos aspectos culturais e interface da educação preventiva.

Alguns fatores de risco para a DAC foram discutidos de forma direta com o cliente e/ou família. Porém, por se apresentarem reservados e tímidos sobre a sexualidade apenas eram indagados de forma superficial sobre a vida sexual. Era uma questão pouco sinalizada naquela época, por não ser objetivo daquele estudo. Revelaram conflitos por se apresentarem, voluntariamente, inativos sexualmente, evidenciando, assim, a necessidade de investigação e aprofundamento. Situação que foi detectada, na maioria das vezes, por insegurança e medo do cliente para o exercício do ato sexual, pensando na possibilidade de volta do quadro cardiológico (SILVA, 2003).

Dados da literatura assinalam que o indivíduo cardiopata, assim como em qualquer outro processo de adoecer, sofre com a interferência da doença em sua 
sexualidade. A idade, o sexo do cliente, a terapêutica medicamentosa utilizada, a qualidade da vida sexual, a relação com o parceiro e o tipo de orientação que recebe da equipe de saúde; bem como o sentimento que nutre e o conhecimento que possui com relação à sua patologia, interferem em sua vida sexual. Sentimentos como ansiedade, medo de morrer, depressão e baixa auto-estima, levam a alterações do desempenho na vida sexual do indivíduo (ROMANO et al., 1998; SILVA, 2003). Tais fatos, por si, confirmam a relevância do presente estudo.

Concordamos com Passador (2004) que a enfermagem, enquanto profissão comprometida em atender o ser humano na sua totalidade, não pode desconsiderar a expressão da sexualidade e, desta forma, deve se comprometer e se responsabilizar em conhecer e intervir em situações que exigem cuidados/assistência de enfermagem, referentes à dimensão sexual.

Sabemos que o aspecto educacional tem se apresentado fundamental para a diminuição da ocorrência dos fatores de risco para a DAC e suas implicações na vida dos clientes. Baseando nestes referenciais, justificamos o presente estudo, propondo problematizar e intervir de forma educativa com os clientes portadores de coronariopatias, buscando possíveis soluções conjuntas às suas dificuldades e entendimento sobre os fatores de risco para essas patologias, tendo em vista as implicações para a sua sexualidade; buscas que nos levaram a traçar os objetivos seguintes. 
3 Objetivos 
- Identificar junto aos clientes portadores de coronariopatias as dificuldades em relação aos fatores de risco quanto à sua doença, associando-as à sua sexualidade;

- Traçar um programa educativo com os clientes coronariopatas sobre fatores de risco cardiovasculares, tendo em vista as implicações da doença para o exercício da sua sexualidade. 
4 Preferencial Oeóxico 


\subsection{Doença Arterial Coronariana}

A DAC tem papel de destaque dentre as doenças cardiovasculares (DCV). No ano de 1990, foi a causa mais comum de mortes no mundo (CARVALHO; SOUZA, 2001) e deve continuar em lugar de destaque até o ano de 2020 (VALE; MARTINEZ, 2001). Tavares (2001) salienta que são patologias que mais afetam a saúde da população mundial, traduzindo-se nas maiores causas de morbidade e mortalidade na Europa, nos Estados Unidos da América e também no Brasil (CAMMERER; MANFROI; MASCARENHAS, 2001). Representam, em países desenvolvidos, cerca de 50\% das mortes entre homens e mulheres, com mais de 30 anos e são responsáveis por um terço de todas as mortes na América Latina. Em 1930, representavam 11,8\%; em 1980, 30,8\% e em 1994, constituíam 28\% de todas as mortes no Brasil (TIMERMAN; SOUZA; SERRANO JR., 2001). Os estudos de tendência de mortalidade por doenças cardiovasculares no Brasil datam, em sua maioria, da década de 1980 e abordam populações de alguns Estados e capitais, registrando declínio da tendência de mortalidade no Estado de São Paulo, desde 1976 (TIMERMAN; SOUZA; SERRANO JR., 2001).

As DCV, por apresentarem elevada morbi-mortalidade, repercutem na qualidade de vida das pessoas reduzindo sua autonomia e produzindo impacto econômico, constituindo-se em um dos maiores problemas de Saúde Pública, em todo o mundo (GIANNINI; FORTI; DIAMENT, 2000). Pesquisas demonstram que as doenças isquêmicas, associadas ao acidente vascular cerebral (AVC), representam as causas mais freqüentes de mortes nos países industrializados, tendo como substrato etiopatogênico a aterosclerose (MANFROI et al., 1998; BRAUNWALD et al., 2000; TIMERMAN; CARDOSO; PAIVA, 2003). 
O processo aterosclerótico tem o estudo de sua patogenia e caracterização morfológica datando do final do século XIX e começo do século XX (HIGUCHI; GUTIERREZ, 2002). Trata-se de um processo progressivo que afeta um quarto da população mundial, principalmente, nos países industrializados e está intimamente ligado ao estilo de vida e hábitos alimentares (CAMPOS, 1988). Associam-se a esse quadro as grandes exigências do mercado de trabalho, extremamente competitivo, além do excesso de trabalho existente, a influência da mídia na formação e condução da vida das pessoas em todos os sentidos, além de outros fatores; prejudicando com isto, o nível de vida individual e coletivo.

A aterosclerose vem sendo reconhecida como problema significativo de saúde desde o início do século passado. A expressão é utilizada para descrever lesão das grandes e médias artérias com depósito na íntima de placas amarelas que contêm colesterol e material lipóide (INTROCASO, 2001). A doença foi constatada sob formas severas, em múmias egípcias com mais de 3.500 anos de existência (RUFFTER, 1911). Estudos de sua gênese têm provado tratar-se de uma proliferação de células musculares lisas, deposição de colesterol e infiltração de células mononucleares. A placa aterosclerótica é muito complexa. Tem estrutura heterogênea e comportamento biomecânico também complexo, com grande parte do processo aterosclerótico ocorrendo pela infiltração de células da circulação sangüínea para locais específicos da parede vascular (HIGUCHI; GUTIERREZ, 2002). A palavra derivou do grego Athera que significa "papa de aveia" e de Sclerose que quer dizer endurecimento (ARTERIOSCLEROSIS, 1981; CAMPOS, 1988).

A DAC tem epidemiologia que recebe influência da cultura, sexo e, possivelmente, da etnia do indivíduo (DANTAS, 1996; COELHO; TOLEDO, 2001). 
Os processos de industrialização e urbanização provocaram e induziram transformações demográficas e epidemiológicas no país. Os avanços científicos e tecnológicos alcançados a partir de 1940, tornaram possível tratar e prevenir as doenças infecciosas levando a um aumento da expectativa de vida e, assim, a um maior tempo de exposição da população aos fatores de risco para desenvolvimento de coronariopatias (KALACHE, 1996; LOTUFO, 1996; OMS, 2003). A sociedade teria que mudar seu conceito de atendimento, saindo do foco emergencial para viver a experiência da assistência ao cliente portador de doenças crônicas (OMS, 2003). O Banco Mundial, em 1991, publicou o trabalho "Brasil: novo desafio à saúde do adulto", no qual há indicação de que as mudanças do padrão de vida rural para a vida em centros urbanos colocaram a população em contato com novas ameaças como o uso de alimentos industrializados, cigarros, bebidas alcoólicas, trânsito, falta de exercício físico, estresse causado pelo trabalho, entre outros (BANCO MUNDIAL, 1991).

As doenças crônico-degenerativas, na década de 1990, eram definidas como aquelas caracterizadas por história natural prolongada, multiplicidade de fatores de risco, complexas interações de fatores etiológicos e biológicos conhecidos e desconhecidos, longo período de latência, longo curso assintomático, com curso clínico em geral prolongado e permanente, manifestações clínicas com períodos de remissão e evolução para graus variados de incapacidades ou para a morte (LESSA, 1998). A DAC, diante da alta incidência e prevalência, incluiu-se neste grupo de atenção.

\subsubsection{Fatores de risco}

Ao se tornar epidemia nos Estados Unidos da América (EUA), a DAC mereceu investigação visando detecção de suas causas, controle e educação preventiva. O termo 
fator de risco surgiu, inicialmente, em um artigo médico, em 1963, denominado Fatores de risco em doença cardíaca coronariana (GIANNINI; FORTI; DIAMENT, 2000). O desenvolvimento do conceito de fatores de risco e suas relações com a incidência de coronariopatias decorreram de estudos epidemiológicos prospectivos realizados nos Estados Unidos (BRAUNWALD, 1999; MORIGUCHI; VIEIRA, 2000).

No início da década de 60, do século passado, o Estudo de Framingham realizado nos EUA, começou a estabelecer relação entre estilo de vida e DAC (LESSA, 1999). Pesquisas demonstram associações com aumento de concentração de colesterol plasmático, tabagismo, hipertensão arterial sistêmica (HAS), diabetes mellitus (DM), obesidade, idade, sexo e a ocorrência de coronariopatia (BRAUNWALD, 1999).

Desde o primeiro relato no estudo de Framingham destacou-se que os fatores de risco pareciam estar ligados ao surgimento da doença aterosclerótica e, assim, tornou-se necessário conhecer os critérios da comunidade científica para a correta identificação de um dado como fator de risco, exigindo um refinamento e a redefinição da expressão fator de risco que se classificou, a partir de então, como um elemento mensurável, como causas de uma enfermidade e um fator preditivo, significativo e independente quanto ao risco futuro de desenvolver doença (VALE; MARTINEZ, 2001).

A definição de fator de risco, relacionada às $\mathrm{DCV}$, considerando a etiologia da doença e as características genéticas do indivíduo como história familiar de coronariopatia prematura, presentes em indivíduos abaixo de 55 anos no sexo masculino e 65 anos no sexo feminino, tem caráter abrangente, traduzindo-se em qualquer hábito ou característica que possa ser usada para prever a probabilidade de um indivíduo desenvolver a doença (STAMLER, 1991). Assim, fator de risco é uma condição que aparece associada a um aumento significativo de ocorrência de eventos clínicos da doença, favorecendo seu 
desenvolvimento (ARMAGANIJAN; BATLOUNI, 2000). São, desta forma, condições que podem predizer a possibilidade de um indivíduo desenvolver determinada doença.

De acordo com a classificação desses fatores de risco, encontra-se na literatura o uso de terminologias distintas como modificáveis e não modificáveis, alteráveis e não alteráveis, mutáveis e não mutáveis, reversíveis e não reversíveis, além de controláveis e não controláveis.

Cabe ressaltar que há escassez de definições de fatores de risco não modificáveis na literatura, porém Évora e Roselino (2002) definem esses fatores como sendo aqueles nos quais não se pode exercer influência no sentido de mudá-los, e desta forma, não podem ser modificados ou excluídos.

Smeltzer e Bare (1994) denominam fatores de risco modificáveis como fatores de risco reversíveis, passíveis de serem controlados pelo indivíduo podendo alterar seu estilo de vida e hábitos pessoais. Colombo (1995) define fatores de risco modificáveis como aqueles sobre os quais o cliente e a equipe de saúde podem atuar através da alteração de hábitos de vida; Évora e Roselino (2002) ressaltam que são fatores controláveis, podendo ser controlados e até excluídos.

Nesse sentido, os fatores de risco cardiovasculares relacionados à aterosclerose podem ser divididos de acordo com suas possibilidades de modificação, quer seja através de mudanças de comportamento ou tipos de tratamento indicados. Assim, temos os grupos de fatores de risco modificáveis e os não modificáveis (KANNEL, 1995; DANTAS, 1996; BRAUNWALD, 1999). 


\subsubsection{Fatores de risco modificáveis}

De acordo com Braunwald (1999), os fatores de risco modificáveis incluem tabagismo, a HAS, a intolerância à glicose e diabetes mellitus não insulino-dependente, sedentarismo, obesidade, uso de anticoncepcionais hormonais, estresse e dislipidemia.

O tabagismo é um fator de risco considerado pela OMS, como a principal causa de morte evitável em todo o mundo, traduzindo-se na maior causa isolada de morte prematura no mundo desenvolvido, entre indivíduos na faixa etária de 35 a 69 anos, contribuindo, sobremaneira, para ampliar o efeito de outros fatores de risco coronários. Nos Estados Unidos da América, 25\% da população com idade a partir dos 18 anos fumam (BRAUNWALD, 1999). No Brasil, estudos revelam que o tabagismo é o único fator de risco independente, correlacionado com o infarto agudo do miocárdio e que tem alta prevalência entre os portadores desta patologia (MANFROI et al., 1998). De acordo com dados do Instituto Nacional de Câncer (INCA) (2002), os derivados do tabaco causam quase 50 doenças diferentes, incluindo as DAC. Tais estudos ainda demonstram que o tabagismo é responsável por 200 mil mortes, por ano, no Brasil; sendo 23 mortes por hora e dessas, $25 \%$ são causadas por doença coronariana.

A hipertensão arterial sistêmica é uma patologia com alta prevalência nos EUA e outros países ocidentais, tendo característica de aumentar com a idade. O terceiro National Health and Nutrition Examination Survey (NHANES III) (1991), conduzido entre 1988 e 1991, documentou uma prevalência geral de HAS em adultos americanos de 24\%. A estimativa para o Brasil é de que $15 \%$ a $20 \%$ da população adulta (considerada acima de 18 anos) possa ser rotulada como hipertensa, constituindo-se na maior causa de mortalidade, correspondendo a $35 \%$ dos óbitos totais no País de acordo com dados descritos na IV Diretrizes Brasileiras de Hipertensão Arterial (SOCIEDADE BRASILEIRA DE 
HIPERTENSÃO ARTERIAL, 2002; POLANCZYK, 2002). Estudos assinalam a prevalência da HAS em cerca de 50 milhões entre os norte-americanos, e índices de $12 \%$ a 35\% em diferentes regiões brasileiras (BRANDÃO et al., 2003a).

A Organização Pan-americana de Saúde (OPAS) (2003) estima que 177 milhões de indivíduos são diabéticos, portadores, em sua maioria, de diabetes tipo 2, e dois terços deles vivem em países em desenvolvimento. Em clientes diabéticos, o risco para o desencadeamento de cardiopatia coronária está aumentado em 2 a 4 vezes. A DAC é a principal complicação de diabetes mellitus insulino-dependente ou não. Aproximadamente, $80 \%$ dos adultos diabéticos morrem por DCV e, como fator complicador, cerca de $95 \%$ dos portadores de diabetes mellitus não insulino-dependentes, nem sabem que possuem a doença. No Brasil, cerca de 05 milhões de pessoas são portadoras da doença, que acomete, principalmente, a faixa etária entre 30 e 69 anos (BRAUNWALD, 1999); apresentando-se em homens e mulheres, com maior potência no sexo feminino (MORIGUCHI; VIEIRA, 2000; CARVALHO; SOUSA, 2001).

Évora e Roselino (2002) mencionam que um indivíduo é considerado sedentário quando seu trabalho não envolve atividade física e quando ele não pratica nenhum esporte ou qualquer outra atividade. Assim, o sedentarismo é considerado outro fator de risco modificável sendo que o estudo Behavioral Risk Factor Surveillance System do Centers for Disease Control, realizado em 1991, demonstrou que a inatividade física está diretamente, relacionada com a idade, variando de 55\% em indivíduos com idade entre 18 e 34 anos e $62 \%$ naqueles com idade a partir de 55 anos (BRAUNWALD, 1999). Estudos epidemiológicos observacionais têm demonstrado que a atividade física regular reduz o risco de eventos de DAC (KOCH; SALERMO de MINA, 1992; BRAUNWALD, 1999; OPAS, 2003). 
Por vez, a obesidade é um problema de saúde pública nos países desenvolvidos (BRONSTEIN, 1996) e foi reconhecida como uma doença em 1997, pela Organização Mundial de Saúde. Dados encontrados no National Health and Nutrition Examination Survey (NHANES III, 1991) confirmam estes referenciais, quando indicam que um terço dos americanos com idade a partir de 20 anos, estão acima do peso (KUCZMARSKI et al., 1994). Dados da OPAS (2003) confirmam que o excesso de peso afeta mais de um bilhão de pessoas no mundo, sendo que cerca de 300 milhões destes indivíduos se apresentam clinicamente, obesos. No Brasil, a prevalência da obesidade está em 13,3\% entre as mulheres contra 5,9\% entre os homens (COLOMBO et al., 2003). O indivíduo é considerado com sobrepeso quando o seu IMC está entre 25 e $29,9 \mathrm{Kg} / \mathrm{m}^{2}$ e obeso quando seu peso está maior que $30 \mathrm{Kg} / \mathrm{m}^{2}$, com recomendações de índice de massa corporal normal dentro da faixa de 18,5 a 24,9Kg/m² (MARTINEZ, 1996; OPAS, 2003).

As DCV têm se destacado como uma das doenças crônicas associadas à obesidade. A obesidade foi identificada como fator de risco para a doença arterial coronariana desde o estudo de Framingham quando constatou-se que o ganho de peso durante a idade adulta aumenta o risco de DAC em ambos os sexos, independente da presença de outros fatores (COLOMBO et al., 2003).

Quanto ao estresse, os pesquisadores têm constatado relação desse com a angina pectoris e o infarto agudo do miocárdio, salientando que vêm ocorrendo após situações de conflito pessoal grave (MORALES CALATAYUD, 1991; SILVA, 2003). A depressão e ansiedade têm contribuído para o aumento da morbi-mortalidade em clientes portadores de DAC (DEVON; ZERWICK, 2003). A reação ao estresse é o mecanismo de defesa contra eventos agressores, internos ou externos ao indivíduo, que tem comportamento normal; tornando-se um elemento patológico quando a capacidade de 
adaptação não é suficiente e, assim, se caracteriza como um causador de doenças (FERREIRA, 2000).

A dislipidemia, mais comumente associada à DAC, é a hipercolesterolemia, manifestada pelos níveis plasmáticos elevados de colesterol LDL (lipoproteína de baixa densidade) (FARMER; GOTTO JR, 1999). A hipercolesterolemia, por estar associada ao desenvolvimento de coronariopatias, tem sido estudada intensivamente, desde o século XIX, quando os pesquisadores demonstraram que as placas ateroscleróticas estavam carregadas de colesterol (FERREIRA, 2000). Desta forma, constatou-se que o colesterol é um dos componentes para o desenvolvimento da aterosclerose e, assim, leva ao aumento do risco de cardiopatias. Dados disponibilizados pela OPAS (2003) confirmam que o alto nível de colesterol no sangue causa 4,4 milhões de mortes. Tem maior incidência entre indivíduos com diabetes mellitus comparados aos não portadores da patologia, com mesmo grau de obesidade; levando também à ocorrência freqüente de angina pectoris e infarto agudo do miocárdio (FERNANDES et al., 2000). Destaca-se, então, a necessidade de manutenção de valores de colesterol total (níveis menores que 200mg/dl), LDL e triglicerídeos (níveis menores que $150 \mathrm{mg} / \mathrm{dl}$ ); além de níveis mais elevados de lipoproteína de alta densidade (HDL) (níveis maiores ou iguais a 40 mg/dl) (GUIMARÃES, 2003).

\subsubsection{Fatores de risco não modificáveis}

No grupo dos fatores de risco não modificáveis temos a raça, sexo e idade; história familiar e ocorrência da menopausa (COON; TAYLOR; CASEY, 1992; MANCILHA-CARVALHO, 1992; KANELL, 1995).

O sexo masculino tem sido relacionado a um pior prognóstico cardiovascular em adultos, porém seu impacto em indivíduos de idades mais jovens é pouco conhecido 
(BRANDÃO et al., 2003b). Desta forma, vem sendo reconhecido como fator de risco para a doença isquêmica cardíaca, sobremaneira, em homens com idades inferiores a 50 anos, uma vez que até essa idade tem risco três vezes maior que a mulher, na mesma faixa etária, de sofrer um infarto; situação que se modifica a partir dos 50 anos (quando a incidência da doença diminui entre os sexos), com as mulheres tornando-se vulneráveis tanto quanto os homens ao referido evento isquêmico, após a menopausa (DANTAS, 1996).

A história familiar (hereditariedade) de DAC influencia o risco aterosclerótico, que pode se iniciar na infância, como tem sido evidenciado em estudos que confirmam a presença de aterosclerose coronariana nas famílias (KANNEL; DAWBER, 1972; BRAUNWALD, 1999; ARMAGANIJAN; BATLOUNI, 2000). Sabe-se que os genes contribuem para a etiologia e patogênese das anormalidades da fisiologia e do comportamento humano e estudos de Pyeritz (1999) e Silva (2004) ressaltam que há cerca de 100 genes citados como possíveis de influenciar as lesões ateroscleróticas. A história familiar positiva para a DAC tem sido um fator de risco forte e independente para a doença, influenciando o risco aterosclerótico desde a infância do indivíduo (FARMER; GOTTO JR, 1999). A evolução da lesão aterosclerótica é lenta, inicia-se cedo e dura dezenas de anos (CAMPOS, 1988; AZEVEDO et al., 1991).

Assim, nos períodos de vida que compreendem a infância e adolescência é possível, então, trabalhar na atenção primária no sentido de evitar o surgimento de DAC futura, reduzindo/evitando a ocorrência dos fatores de risco modificáveis em populações jovens, de meia-idade e idosos; além de orientações sobre estilo de vida, precauções e tratamento dos fatores de risco não modificáveis para clientes e família que apresentam a prevalência elevada de DAC (MORIGUCHI; VIEIRA, 2000). 
A idade também é um fator de risco para a DAC que vem apresentando significativas alterações. No "Framingham Heart Study" identificou-se que o início da DAC sintomática ocorre, tipicamente, cerca de 10 anos antes em homens, mas a incidência aumenta rapidamente em mulheres na menopausa (BRAUNWALD, 1999). Atualmente, com o aumento da expectativa de vida da população, com o envelhecimento das pessoas, evidencia-se a necessidade de pesquisas com idosos, pois trata-se de um grupo etário que além de apresentar características morfo-fisiológicas, psicológicas e socioeconômicas diferenciadas dos demais indivíduos tem maior exposição às doenças crônicodegenerativas, como a DAC (MARAFON et al., 2003).

Segundo Liberman (2002), a doença cardíaca é a principal causa de morte no cliente idoso e a idade se apresenta como o principal fator de risco para a doença coronária, devido ao maior número de placas, pela diminuição da reserva cardíaca, pelo perfil trombogênico desfavorável e pela maior prevalência de doenças sub-clínicas e comorbidades cardíacas e extra-cardíacas.

As mudanças no estilo de vida parecem ser uma forma segura e compatível de tratamento para a DAC (ORNISH; BROWN; SCHERWITZ, 1990). Há índices de que as taxas de mortalidade por DAC e AVC declinaram, 50\% e 60\% respectivamente, no período de 1970 a 1994, em conseqüência do controle de vários fatores de risco para a aterosclerose, principalmente da HAS no Brasil (INTROCASO, 2001).

Giannini, Forti e Diament (2000) e Tavares (2001) comentam que muitas mortes poderiam ser evitadas com medidas preventivas e/ou intervencionistas dos fatores de risco para as doenças cardiovasculares, pois estas medidas reduziriam seu papel patogênico e com isso minimizaria ou até eliminaria o risco de aparecimento da doença e ainda sua evolução, quando já instalada. 
Compartilhamos com Giannini, Forti e Diament (2000) e Farris, Haney e Dunet (2004) quando enfatizam que a implementação de programas de prevenção de doenças crônicas visando a redução de morbi-mortalidade diminui as desigualdades e promove a saúde dos indivíduos.

Estudos de Baberg, Jager e Kahrman (2000) e de Steffenino et al. (2003) comentam a existência de investigações que destacam a importância do controle de fatores de risco em clientes portadores de doenças cardiovasculares, assinalando que a implementação de prevenção secundária nos hospitais, durante a internação, visando à diminuição de manifestações agudas e intervenções têm sido insatisfatórias, especialmente pela falta de educação efetiva dos clientes acerca do seu problema de saúde e de sua nova condição de vida.

A relação sexual de forma moderada, por exemplo, com orientações médicas, não é considerada prejudicial e mesmo diante do número limitado de estudos acerca desse tema, referenciais práticos nos têm evidenciado a necessidade de trabalhar as questões da orientação e educação preventivas com relação aos clientes acometidos pela DAC.

Bertazone (1998) refere que doenças crônicas podem afetar a vida de um indivíduo e reflete, inclusive, no exercício de sua sexualidade. Estudo de Favarato e Aldrighi (2001), com mulheres coronariopatas no climatério após a menopausa, confirma que a coronariopatia interfere na qualidade de vida desses sujeitos, limitando sua capacidade física e desempenho de atividades diárias, incluindo a diminuição do desejo sexual.

Ooijen (1995) constata a situação supracitada afirmando que mesmo doentes, os seres humanos não separam sua sexualidade do todo, pois as relações com os outros e a sexualidade formam o nosso todo para vivermos. 
A sexualidade é uma forma de expressar lealdade, paixão, estima e afirmação de um corpo que tenta manter seu equilíbrio e funcionamento; e não meramente sexo (BUTLER; LEWIS, 1985).

Vitiello (1996) ainda ressalta que a sexualidade do indivíduo pode ser afetada pelas condições mórbidas sistêmicas de forma direta (quando o coito ou outras manifestações da sexualidade fica comprometido ou impossível), e indiretamente (quando as conseqüências resultam de tratamentos ou de aspectos emocionais ligados à doença).

A presença da enfermidade demanda tratamento da condição física ou metabólica, além das questões psicossociais (KOLODNY; MASTERS; JOHNSON, 1982). O exercício da sexualidade, por exemplo, é uma situação que, mesmo sob condições orgânicas adversas, esta manifesta-se e se realiza, mesmo com prejuízos.

A doença e sua terapêutica influenciam a sexualidade, especialmente, porque a doença compromete os aspectos biológico, psicológico e sociocultural que a envolvem.

As DCV afetam indiretamente a sexualidade, levando a seqüelas psicossociais que podem alterar a atividade, os papéis e os relacionamentos sexuais. Fisiologicamente, durante a atividade sexual ocorrem mudanças de freqüência cardiorrespiratória e de pressão arterial e os portadores de IAM, por exemplo, desenvolvem medo do esforço físico e da ansiedade; circunstâncias que poderão levar à dependência, incapacidade e inatividade sexual e conseqüente medo do desempenho sexual (HOGAN, 1985).

Aliadas a essa situação, temos as drogas de uso contínuo para controle e/ou minimização da sintomatologia da doença cardiovascular, como os medicamentos beta bloqueadores que alteram a função sexual por serem bloqueadores dos impulsos simpáticos, vasodilatadores periféricos e diuréticos, ocasionando comprometimentos na ereção, provocando bloqueio na ejaculação e diminuição da libido (HOGAN, 1985). 
Desta forma, várias patologias que acarretam alterações no padrão de normalidade de saúde poderão alterar a vida sexual do indivíduo.

\subsection{Sexualidade Humana}

A sexualidade tem a idade do próprio homem (MÜLLER, 1999). Relatos históricos gregos, romanos e de Sodoma expressam, desde os primórdios da civilização, que o homem se preocupa com a sexualidade e o sexo; este último representando o ponto de contato entre o homem e a natureza, prevalecendo os impulsos primitivos diante da moralidade, vencendo tabus existentes em todas as culturas (BUENO, 2001).

Embora escassos, os primeiros registros da sexualidade humana datam de 22 mil anos e revelam a influência de ambientes socioculturais e políticos, além das funções vital e instintiva. A vida sexual humana, na época pré-histórica, ocorria no momento propício ao acasalamento, obedecendo à lei da natureza (TAYLOR, 1997). Na pré-história, o pênis era entendido como o doador da vida e a vulva como o seu receptor. Os povos primitivos representavam os órgãos sexuais masculinos e femininos em desenhos e esculturas nas cavernas. Em anos posteriores à Idade da Pedra, há registros de estatuetas de marfim e de pedra de mulheres que poderiam representar estados de gravidez, vida e fertilidade.

$\mathrm{O}$ culto ao falicismo continuou pelas montanhas, vales e árvores quando o homem saiu das cavernas e conseguiu vincular o ato sexual à reprodução, ainda acreditando que o ato reprodutivo ocorria por interferência mágica, uma vez que não possuía o conhecimento das relações.

Desde a pré-história, nas figuras rupestres até a contemporaneidade, a sexualidade é explorada pela sua plasticidade de gênero e pelo seu valor místico-espiritual 
de fecundidade. Desta forma, vem determinando a identidade sexual de homens e mulheres através de influências ambientais e sociais, associados aos elementos genéticos, somáticos, psicológicos e sociais (HELMAN, 1994).

No século XVIII, a história da teoria sexual sai da esfera canônica e se torna assunto do Estado, considerando a questão da fisiologia da reprodução e no modo de dominação; priorizando a perpetuação da espécie. No século XIX, os discursos sobre sexo saem do âmbito da Igreja e invadem a medicina, a justiça social e a demografia, gerando pesquisas quantitativas com o objetivo de superar o moralismo e visando produzir uma sexualidade economicamente útil (HAJE, 2005).

Datam do século XIX os primeiros estudos científicos da sexualidade humana, descritos em trabalhos do sexologista Havellock Ellis (1859-1939) e Alfred Kinsey (18941956), e dos fisiologistas William Masters (1916) e Virgínia Johnson (1924). Nestas investigações foram considerados aspectos biológicos: anatômicos, fisiológicos, endócrinos e genéticos; e também os comportamentais como os psicológicos e psiquiátricos (MÜLLER, 1999).

A sexualidade humana, historicamente, tem sido uma preocupação de todos os povos, marcando a diversidade cultural da humanidade (BISON, 1998) e vem sendo descrita como um fenômeno holístico constituído de comportamentos biológicos, intelectuais, espirituais, comportamentais e socioculturais (LOPES et al., 1994).

Para Freud (1987), a sexualidade é a fonte de todos os prazeres e problemas do homem, durante seu ciclo de vida. Assim, a sexualidade transpõe barreiras da corporalidade, alcançando níveis só atingidos pelas emoções e pensamentos do ser humano.

Bertazone (1998) enfatiza que a sexualidade humana se manifesta em todas as fases do viver de um ser humano, é inerente à pessoa e determina um modo individual de 
ser daquele sujeito. Constitui-se um fator intrínseco da individualidade de toda pessoa (WEBB, 1985).

Vitiello (1994) afirma que a sexualidade manifesta-se em todas as fases da vida do ser humano e sua influência permeia todas as manifestações humanas, do nascimento à morte. Desta forma, percebemos que a sexualidade envolve aspectos orgânicos e psicossociais, numa relação de interdependência. Nesse sentido, sofre influências de aspectos relacionados à história pessoal de cada indivíduo como seus hábitos, comportamentos, atitudes e significados aprendidos (KUSNETZOFF, 1987).

Haje (2005) sublinha que a sociedade vive, desde o século XVIII, uma fase de repressão sexual, com o casal procriador como modelo e o sexo apenas para função reprodutora. A autora salienta que esta hipótese de repressão sexual é discutida por Foucault (1988) quando comenta que a partir do século XVIII houve uma proliferação de discurso sobre sexo, especialmente na igreja, escola, família e consultórios médicos, visando ao controle do indivíduo e da população. Nesta fase adotou-se um vocabulário para falar de sexo, com local e pessoa definida para ouvir.

A sexualidade no século XX é discutida por Loyola (2003) a partir do controle da sexualidade feminina e do processo reprodutivo, buscando construir um modelo de reprodução que se pauta no desmembramento da sexualidade e reprodução dirigida ao prazer e desvinculada dos laços afetivos e sociais, caracterizando um "jogo irônico" da indiferença sexual.

Hogan (1985) assinala que a sexualidade humana é envolvida por aspectos biológicos, psicológicos, socioculturais e éticos.

Os componentes da sexualidade humana, considerando-se a abordagem biológica, psicológica e social, assim se manifestam: a biológica envolve o corpo físico 
(que sente, vê e é visto pelas outras pessoas) incluindo os sexos cromossômicos, gonodal e genital, e os caracteres sexuais secundários; a abordagem psicológica inclui nossa mente, emoções, afetos e desejos (onde se encontra a identidade sexual) e a abordagem social refere-se ao contexto de mundo, incluindo os papéis sociais de gênero e afetivo-sexual (COSTA, 1994).

Foucault (1988) enfatiza que a sexualidade humana é socialmente construída, pois se trata de produto do encadeamento da estimulação dos corpos, da intensificação dos prazeres, da incitação ao discurso, da formação de conhecimentos, dos reforços de controle e resistências.

O comportamento sexual nas diferentes culturas tem caráter biológico da sexualidade humana, sofrendo influência do meio ambiente e da cultura, pois do ponto de vista antropológico, estuda-se a constituição do ser humano como produto de processos concretos de relações entre os indivíduos e estes com a natureza. Assim, Mott (2005) afirma que a realidade sexual é variável em diversos sentidos. Muda no interior dos próprios indivíduos, dentro dos gêneros, nas sociedades, diferindo de gênero para gênero, de classe para classe e de sociedade para sociedade.

O comportamento sexual humano reproduz-se no contexto da cultura, nos estilos de vida adotados no espaço social onde se vive; considerando os aspectos políticos, econômicos, históricos, religiosos, entre outros. Nesse sentido, deve-se conscientizar que sociedades diferentes possuem padrões e códigos de condutas diferentes, e nem sempre o natural e normal para uns tem o mesmo significado para outros indivíduos.

Para Saito (1996), a manifestação da sexualidade ocorre através das vertentes: histórica (a sexualidade é construída historicamente vinculada a interesses políticoeconômico-sociais, culturais, religiosos, moral e ético); cultural (compreende aspectos 
cognitivos, crenças, tabus, mitos e rituais que tornam aspectos em algo aceitável ou não); e a vertente de cunho social (que envolve normas, valores e atitudes que incorporamos em nossa personalidade). $\mathrm{O}$ aspecto sexual é parte deste processo de socialização.

Do ponto de vista biológico, quando nosso organismo responde a todas as fases da resposta sexual, nossa sexualidade é "normal".

Sob o ponto de vista psicológico, está "normal” quando há satisfação com o comportamento sexual, próprio e da (o) parceira (o).

E por fim, sob o ponto de vista social, é considerada "normal" quando as práticas sexuais são aceitáveis pela sociedade. As situações que são caracterizadas como anormais são classificadas como disfunção sexual, inadequação sexual e desvio sexual, respectivamente (CAVALCANTI, R.; CAVALCANTI, M., 1996; MELO, 2004).

A partir da década de 60, considerando o aspecto histórico, ocorreram mudanças sociais que alteraram os valores sociais relativos à sexualidade separando os efeitos reprodutivos dos efeitos prazerosos e sociais de atividade sexual (CORREIA, 1997).

$\mathrm{Na}$ década de 70, ocorre a descoberta de novas drogas, do anticoncepcional, a mulher apresenta-se como força de trabalho necessária à produção (BISON, 1998). Geovanini et al. (1995) ressalta que esse movimento traduziu-se num momento de fortalecimento da medicina curativa, pois com a consolidação da industrialização no Brasil, a assistência centra-se no curativo e os currículos de enfermagem, por exemplo, passam a priorizar a assistência curativa e o ensino especializado.

Com o aumento das doenças sexualmente transmissíveis e da Síndrome de Imunodeficiência Adquirida em 1980, a sexualidade humana passou a ser discutida na mídia falada e escrita, e o tema invadiu a vida das pessoas com uma abordagem mais 
explícita, visando intervenções profissionais em nível individual, familiar e coletivo para possíveis modificações do estilo de vida sexual dos indivíduos (BUENO, 2001).

\subsubsection{Educação Sexual}

Entendendo a sexualidade humana como um fenômeno holístico constituído de comportamentos biológicos, intelectuais, espirituais, comportamentais e socioculturais, a temática torna-se bastante complexa para abordagem, pois interliga e interlaça-se em diferentes movimentos (BISON, 1998). Müller (1999) salienta que vários aspectos da sexualidade vêm sendo estudados, mas novas facetas têm se apresentado para serem discutidas e apresentadas. Nesse sentido, a educação no âmbito da sexualidade sempre ocupou lugar de destaque na tentativa de operacionalizá-la de forma correta ou ainda a mais adequada possível.

Data do século XVIII, na França, a educação sexual (para controle e repressão das manifestações sexuais infantis); caminhando para a preocupação com a prevenção de moléstias sexualmente transmissíveis e aprendizagem sobre a função sexual da reprodução (BISON, 1998).

No Brasil, a educação sexual surge com objetivos de controle e repressão no início do século XX, como proposta de educação sexual nas escolas (em 1928, sem sucesso).

Em 1970, houve o ressurgimento da educação sexual nas escolas (tentativa que foi proibida pelo regime ditatorial do governo federal, naquela época). Ainda na década de 70, no âmbito de segundo grau, renasceu após as mudanças na sociedade que adotava novos conceitos éticos e morais (SAYÃO, 1995). Nesse período, discutia-se da liberação de 
costumes às doenças decorrentes de práticas inseguras, num cenário onde a mídia impressa e falada trazia o tema para os lares dos cidadãos (BUENO, 2001).

Ainda neste contexto, a OMS (1986) publica o documento "Conceito para a Saúde Sexual", e enuncia os pontos para a abordagem da sexualidade:

- Capacidade de apreciar e controlar o comportamento reprodutivo sexual conforme a ética social e pessoal;

- Libertação do medo, da culpa, de falsas crenças e outros fatores psicológicos que inibam a resposta sexual e prejudiquem as relações sexuais;

- Libertação de distúrbios orgânicos, doença e deficiência que interfiram com as funções sexuais e reprodutivas.

A partir de então, os profissionais da saúde começam a encontrar dificuldades para tratar o cliente e abordar sua sexualidade, uma vez que assinalam/acrescentam a existência da dimensão sexual no cliente.

Gir (1997) sublinha que os enfermeiros tratam os clientes como assexuados omitindo aspectos da dimensão sexual no tratamento, no cuidado e no emocional do paciente sobre o exercício de sua sexualidade.

Bison (1998) salienta que vários investigadores analisam as conseqüências do preparo inadequado do profissional de saúde nas questões da sexualidade; situação que interfere no processo do cuidado da saúde e na cura do cliente que permanece com suas necessidades sexuais latentes.

Müller (1999) ainda enfatiza que alguns autores assinalam que há uma recusa das pessoas para falar abertamente sobre as questões sexuais e sugere o diálogo sem preconceitos, franco, para enfrentamento e compreensão da sexualidade e do sexo. 


\subsubsection{Educação Sexual e Enfermagem}

Num momento de mudança de paradigma no ato assistir/cuidar do ser humano, vive-se a saída do modelo biomédico (onde o ser humano é visto por partes-corpo e mente) e caminha-se para a atenção/assistência integral ao ser humano (GARCIA, 1993).

Contemplando esse modelo, o profissional da saúde preocupa-se com a dimensão sexual dos indivíduos e para a assistência/cuidado ideais é necessário domínio/conhecimento com relação aos aspectos sexuais (HOGAN, 1985).

O currículo de enfermagem sempre "pregou" que alunos, seres humanos, não devem expressar suas emoções (BISON, 1998); reforçando uma formação superficial das questões da emoção. Um aluno que não pode sentir emoções, pouco discute sobre sexualidade, sobre as formas de emoção e expressão.

Para Zalar (1982), a dificuldade de o enfermeiro assistir o ser humano em sua dimensão sexual advém, entre outros aspectos, de sua formação que visa atender aos aspectos físicos e emocionais da doença, excetuando o desenvolvimento psicossexual dos seres humanos.

Estudos de Pelá et al. (1995), Ferreira e Figueiredo (1997), Pereira et al. (2000) e Melo (2004) ressaltam a dificuldade e o despreparo do enfermeiro para lidar com a sexualidade humana e suas dimensões. Pelá, Gir e Nogueira (2000) ainda salientam que há entendimento limitado dos termos sexo e sexualidade por parte deste profissional.

No século XX, ocorreu a liberação sexual, a dimensão sexual do indivíduo passou a ser amplamente discutida, principalmente, com o advento da Aids. Porém, em nossas vivências e consultando pesquisas sobre a temática, constatamos que faltam informações corretas sobre a sexualidade e que ainda sobressaem as crendices e tabus sexuais (BUENO, 2001). 
Apesar dos movimentos contrários no tocante à formação, na década de 60 , em face às mudanças sociais que alteraram os valores relativos à sexualidade, segundo Melo (2004), constataram-se as primeiras preocupações científicas da enfermagem com a sexualidade quando surgiram artigos relacionados à sexualidade, masturbação e homossexualidade; além de edições sobre sexualidade humana na Nursing Outlook, pesquisas e recomendações de inclusão da sexualidade humana nos currículos de enfermagem; no final de década de 70 e início dos anos 80.

A enfermagem vem trabalhando a promoção da saúde com clientes que já possuem alteração de saúde e que podem ter sua sexualidade atingida como os portadores de cardiopatias, diabetes, acidente vascular cerebral, cânceres, entre outras. Concordamos com Melo (2004) que este trabalho com a disfunção sexual de clientelas específicas pode levar a Enfermagem a habituar-se a trabalhar diariamente com a clientela geral.

Este cuidado com a sexualidade humana e atividade sexual dos clientes implicam, segundo vivências e referências de autores como Carvalho e Teles (2001), na melhoria da qualidade de vida das pessoas portadoras de patologias, como os coronariopatas, pois podem recuperar a capacidade de apreciar a vida e se realizar profissional e amorosamente (MOLASSIOTIS; MORRIS, 1998).

A partir do exposto, afirmamos que estas dimensões da sexualidade estão interligadas e qualquer alteração em uma delas implicará em mudanças nas outras como, por exemplo, uma alteração na função sexual devido a uma cardiopatia produzirá alterações na saúde sexual do indivíduo; uma vez que a função sexual se manifesta sob a forma de resposta fisiológica. Nesta circunstância, o desejo sexual (uma das fases da resposta sexual) também fica comprometido, pois sabe-se que a dor tem capacidade de inibir o desejo 
sexual; fato que imputa a possibilidade do desejo sexual estar anatômica e/ou quimicamente ligado ao centro da dor (KAPLAN, 1983).

Buscando o restabelecimento da autoconfiança do cliente infartado, considerando-o como um ser biopsicossocial, os autores Suedekum, Cassol e de Martino (1995) propuseram um programa de reabilitação cardíaca para pacientes infartados, sem complicação (Fase I) constituído por temáticas referentes a noções fisiopatológicas do infarto agudo do miocárdio, fatores de risco, atividades físicas permitidas, educação sexual, nutricional e medicamentos; com sucesso.

Para Suedekum, Cassol e Martino (1995), a responsabilidade do acompanhamento rigoroso na evolução clínica do cliente é do enfermeiro, pois tem interação constante entre clientes e familiares, representando o agente catalisador no processo de reabilitação cardíaca (BODEN; CAPONE, 1984).

A orientação de enfermagem quanto à atividade sexual deve iniciar-se na vida hospitalar com o casal/parceiro, esclarecendo dúvidas e medos com vistas a minimizar ansiedades (MARIA; MODENA, 1984; SUEDEKUM; CASSOL; MARTINO, 1995); evitando que o cliente/família deixe de vivenciar todos os aspectos da vida cotidiana, incluindo, o exercício da sexualidade.

Cesarino e Casagrande (1998) ressaltam que o enfermeiro é o profissional de saúde que atua de forma mais constante e próxima do cliente. Assim, deve planejar a assistência junto com estes clientes, a partir da avaliação que realiza, considerando os limites e possibilidades do seu contexto de vida. Desta forma, pode estimular a conscientização quanto à situação do cliente com ampliação de sua consciência a respeito de novo estilo de vida, de sua capacidade para optar e se relacionar no mundo em que vive, 
valorizando a experiência e a percepção do educando/cliente (FREIRE, 1990; RODRIGUES; CASAGRANDE, 1996).

A modificação dos fatores de risco em clientes de programas de reabilitação cardíaca diminuiu a mortalidade (KUNIK, 1994) e houve redução de episódios de morbimortalidade quando controlados os fatores de risco em estudos de Manfroi et al. (1998).

Estudos de Baberg et al. (2000) e de Steffenino et al. (2003) salientam a existência de investigações que destacam a importância do controle de fatores de risco em clientes portadores de DCV, assinalando que a implementação de prevenção secundária nos hospitais, durante a internação, visando à diminuição de manifestações agudas e intervenções têm sido insatisfatórias, especialmente pela falta de educação efetiva dos clientes acerca do seu problema de saúde e de sua nova condição de vida. O aspecto educacional tem sido apontado como uma das abordagens mais importantes para a aquisição de conhecimento, pelos clientes, com relação à sua patologia (MILLER; REBER; CHAPMAN NOVAKOFSKI, 2001).

Rodrigues e Casagrande (1996) referem que a finalidade da prática de enfermagem, no geral, tem significado social, uma vez que é possível intervir no processo saúde-doença. As atividades educativas da enfermeira devem iniciar-se na hospitalização para, posteriormente, ter continuidade no domicílio, considerando o contexto de vida do cliente.

Há estudos que evidenciam maior efetividade na redução de riscos cardiovasculares em programas educacionais baseados em cuidados de enfermagem (McPERSON et al., 2002). Ribeiro (2005) assinala que, com relação às doenças cardiovasculares e seus fatores de risco, o profissional enfermeiro é possuidor de conhecimentos e subsídios para uma atuação direta com os clientes já acometidos pela 
patologia ou ainda susceptíveis, trabalhando, inclusive, para a implantação de programas educativos. 
5 Referencial Oérico-OMetodológico 
Utilizamos o referencial teórico-metodológico de Freire (1990), adaptado por Bueno (1997-8), onde o desenvolvimento prático do método foi delimitado por duas fases, sendo a primeira, o levantamento do universo temático, que compreende o identificar dos temas geradores, a organização do material da coleta de dados, a seleção e codificação de palavras e frases registradas/emitidas, além da síntese das palavras e frases selecionadas e ordem dos temas geradores. E a segunda fase, de desenvolvimento das atividades educativas da pesquisa-ação, constituída de planos de ensino relativos aos temas geradores, desenvolvimento da educação conscientizadora e avaliação do processo.

A pedagogia libertadora tem apresentado melhores resultados quando comparada às demais correntes pedagógicas, pois possibilita a participação ativa do educando no processo de aprendizagem, num momento em que as práticas educativas vêm sendo instrumentos de formação contínua de profissionais da área de saúde e também da população em geral, considerando o aspecto da educação em saúde. Cabral (2002) salienta que, durante a utilização desta pedagogia em seu estudo, constatou ser "perfeitamente aplicável na área de saúde”.

Neste sentido, este tipo de metodologia favorece ruptura e processos mais amplos de mudança no contexto da educação em saúde como um todo (PEREIRA, 2003; CYRINO; TORALLES-PEREIRA, 2004). Autores como Farris, Haney e Dunet (2004) ainda salientam que o processo participatório, enquanto método de trabalho, permite a adequação dos programas educacionais ao contexto dos indivíduos e pode reduzir as doenças cardiovasculares.

Experiências com alunos de graduação em enfermagem vêm demonstrando que os pontos positivos da problematização estão nos espaços de diálogo e na problematização 


\section{Referencial OTosica-ONetodologico}

da realidade, pois possibilitam exercício de cidadania aos participantes, numa posição de sujeitos dentro de um processo de ensino-aprendizagem; situação que os permite vislumbrar o mesmo tipo de atuação, mais tarde, enquanto profissionais (LOUREIRO; VAZ, 2000).

As práticas educativas desenvolvidas através da metodologia problematizadora, aplicadas por enfermeiros em suas vivências profissionais, têm permitido confirmar que estas proporcionam reflexão e compreensão dos elementos básicos quanto à realidade de sua doença e dos esquemas terapêuticos utilizados; possibilitando que juntos, sujeitos e profissionais, reflitam e elucidem os problemas (CESARINO; CASAGRANDE, 1998).

A pedagogia problematizadora valoriza o saber do educando e o instrumentaliza para a transformação de sua realidade e de si mesmo; num movimento em que a educação é concebida como prática de liberdade, fundamentada na relação dialógica entre educando e educador para a construção de conhecimentos a partir da vivência e experiência significativa.

A pedagogia libertadora apóia-se nos processos de aprendizagem por descoberta, com os conteúdos de ensino em forma de problemas, com os quais o aluno fará relações de descobertas e construção de leis e conceitos que precisará assimilar (CYRINO; TORALLES-PEREIRA, 2004).

Trata-se de uma pesquisa quali-quantitativa, de cunho humanista mediatizada pela metodologia da pesquisa-ação.

A utilização da pesquisa quali-quantitativa objetiva melhor entendimento do fenômeno estudado, buscando diagnosticar o fenômeno através de sua descrição e interpretação; além de explicá-lo, a partir de relações de nexo causal (NEVES, 1996). O 


\section{Referencial OTórico-ONetodologico}

emprego desta abordagem possibilita maior compreensão do fenômeno, com visão mais abrangente do contexto onde ocorre; assim, se complementando.

O método quantitativo tem sido utilizado para descrever e explicar fenômenos procurando seguir, com rigor, um plano previsto anteriormente, buscando enumerar ou medir eventos, empregando a estatística para análise dos dados (NEVES, 1996).

A abordagem qualitativa preocupa-se com a compreensão dos seres humanos e da natureza de suas transações consigo mesmo e seus arredores (BUENO, 1993; POLIT; HUNGLER, 1995). Alguns pesquisadores ressaltam que nessa modalidade de pesquisa há uma inquietação com um universo de valores e atitudes que correspondem a um espaço mais profundo das relações, dos processos e dos fenômenos, sem se importar com a quantidade, mas sim com a compreensão e entendimento da dinâmica das relações sociais (MINAYO, 1996; BUENO, 2001).

A pesquisa qualitativa permite analisar as preocupações dos sujeitos estudados possibilitando o esclarecimento, o tratamento, a interpretação e a descrição do estudo da realidade (TRIVIÑOS; KOPS, 1991); características que facultam um cunho humanista na investigação, pois pressupõe uma relação efetiva do pesquisador com os sujeitos pesquisados e vice-versa; além de admitir, através da metodologia da pesquisa-ação, estimular e valorizar a subjetividade humana e do sujeito da pesquisa que é considerado e tratado como cidadão que deve discutir, sugerir e decidir sobre sua realidade ou contexto (GIORDANI, 2003).

A pesquisa-ação permite trabalhar ações educativas e de intervenção, a partir de informações coletadas (GIORDANI, 2000); numa ação coletiva de pesquisador/educando, onde atores sociais se comprometem com a resolução ou esclarecimento dos problemas com vistas à transformação da realidade observada (THIOLLENT, 1992). A pesquisa-ação 
facilita, portanto, o envolvimento do pesquisador durante uma prática participativa com os clientes (CESARINO; CASAGRANDE, 1998).

Nesta relação de envolvimento do pesquisador através da prática participativa com os pesquisandos, Bueno (2001) ressalta que a observação participativa é uma técnica de coleta de dados que ajuda o pesquisador a interagir-se com os sujeitos da pesquisa em seu contexto, compartilhando com os pesquisados suas atividades de vida e sentimentos, através de uma relação face a face (HAGUETTE, 1997). Trata-se de uma técnica que ajuda o pesquisador na interação com os sujeitos da pesquisa, no próprio ambiente deles, através do contato direto do fenômeno observado (CESARINO; CASAGRANDE, 1998; CHIZZOTTI, 1991).

Usamos como técnica de coleta de dados a entrevista individual tendo como roteiro um questionário com questões abertas (APÊNDICE A) e utilizamos a observação participante como exploração do local e do cliente. Ainda empregamos o gravador como instrumento de registro de viva voz, pois permite-nos captar e reter pausas de reflexão e de dúvida ou entonação de voz em diversos tipos de expressões, além de erros; elementos que contribuem para a compreensão da narrativa, uma vez que compõem com as idéias e os conceitos, a produção do sentido da fala (QUEIROZ, 1983; SCHRAIBER, 1995). Mesmo cientes da introdução deste terceiro participante no encontro, conforme assinala Amaro (2000), e das restrições do uso do gravador na entrevista pelo fato de, muitas vezes, levar a inibições de respostas por parte do entrevistado, pedimos a permissão para o seu uso e nos servimos da gravação como forma de registro pelas vantagens já mencionadas. Depois de superadas as estranhezas do contato inicial, pesquisador e pesquisados tornaram-se parceiros de trocas (ROMANELLI, 1998), visando uma construção comunicativa (ALONSO, 1995). 
Para as orientações do processo educativo, utilizamos o referencial teóricometodológico de Freire (1990), adaptado por Bueno (1997-1998; 2001), conforme citado inicialmente. 
6 Olletodologia 


\subsection{Natureza do estudo}

Trata-se de um estudo descritivo, exploratório, com abordagem de análise qualiquantitativa.

\subsection{Local do estudo}

O presente estudo foi realizado em domicílios de clientes usuários do Sistema Único de Saúde, portadores do diagnóstico de DAC (AP e IAM), contra-referenciados para seguimento em duas unidades de saúde, no município de Brodowski - SP: na Unidade Mista Hospitalar - Dr Faustino de Castro, onde eram realizados os atendimentos de clientes pelo cardiologista até 31 de junho de 2006, antes da inauguração do Centro de Especialidade Médica - Narcizo Garavini (local onde os agendamentos ocorrem desde a data de 03 de julho de 2006).

O referido município foi fundado em 1913 e está localizado a uma altitude de $861 \mathrm{~m}$, com área total de $280,6 \mathrm{~km}^{2}$ de território. A população estimada pelo Instituto Brasileiro de Gráficos e Estatísticas (IBGE), no ano de 2006, é de 19.616 habitantes possuindo 5144 famílias residentes no município, com renda nominal de $\mathrm{R} \$ 571,47$ (IBGE, 2004). Tem 05 escolas municipais e 06 estabelecimentos de saúde sendo 04 unidades municipais e 02 pertencentes ao setor privado. Nas unidades de saúde municipais incluem 01 Centro de Saúde III, 01 Núcleo de Reabilitação Fisioterápica, 01 Unidade Básica de Saúde e uma Unidade Mista Hospitalar. 


\subsection{População e amostra do estudo}

Após a busca nos prontuários (procedimento descrito no item 6.5) foram selecionados 102 clientes portadores de doença arterial coronariana, com 18 anos ou mais, de ambos os sexos, residentes na cidade de Brodowski-SP.

Para a análise qualitativa consideramos a repetição de respostas semelhantes (fato que ocorreu a partir da trigésima entrevista), mas quantitativamente, adotamos a seleção aleatória com escolha de 01 sujeito por bairro; totalizando 36 sujeitos, tendo em vista que a cidade possui 36 bairros.

Desta forma, a amostra foi constituída por 36 clientes, de ambos os sexos, que possuíam 18 anos ou mais, usuários do Sistema Único de Saúde, portadores do diagnóstico de doença arterial coronariana, contra-referenciados para seguimento no Centro de Especialidade Médica-Narcizo Garavini, na especialidade cardiologia, em seu município de origem (na cidade de Brodowski). Os sujeitos ainda deveriam ser residentes no município de Brodowski e não apresentar restrições e/ou complicações cardiológicas; situações que foram atestadas pelo médico responsável, por ocasião da discussão/aplicação de atividades educativas.

Os sujeitos foram localizados em duas unidades de saúde: na Unidade Mista Hospitalar - Dr Faustino de Castro, onde eram realizados os atendimentos de clientes pelo cardiologista (no período de 04 de janeiro de 2004 a 31 de junho de 2006), antes da inauguração do Centro de Especialidade (local fundado em 03 de julho de 2006) e no Centro de Especialidade Médica-Narcizo Garavini, onde os agendamentos ocorreram desde a data citada anteriormente. Nestes serviços foram realizadas buscas em prontuário do 
cliente, vislumbrando dados de identificação (que possibilitassem o primeiro contato como nome, telefone ou endereço), bem como diagnóstico principal.

\subsection{Aspectos éticos e legais}

Primeiramente, obtivemos a autorização para execução deste projeto com o Prefeito Municipal (APÊNDICE B) e com a Secretária da Saúde do município (APÊNDICE C) em questão. O projeto de pesquisa foi encaminhado ao Comitê de Ética em Pesquisa da Universidade de Ribeirão Preto (APÊNDICE D) e, após a apreciação e aprovação do Projeto (em 31 de outubro de 2006, sob registro ComÉt: 080/06 - ANEXO 1) por esse Comitê de Ética em Pesquisa com Seres Humanos, foram realizados os devidos procedimentos.

\subsection{Período de desenvolvimento da pesquisa}

Esta investigação ocorreu do mês outubro de 2006 (após a autorização do Comitê de Ética em Pesquisa com Seres Humanos da Universidade de Ribeirão Preto) a julho de 2007, constituindo-se de três etapas: a primeira fase contemplou o levantamento de dados em prontuários dos clientes como identificação - nome, endereço, telefone e diagnóstico principal; num segundo momento foi feito contato telefônico com cada participante e, por fim, a realização da entrevista propriamente dita para coleta de dados para análise.

Para a coleta dos dados no prontuário consideramos os clientes atendidos no período de 01 de janeiro a 31 de dezembro de 2006 após ciência, aquiescência e assinatura do Termo de Consentimento Livre e Esclarecido, pelos clientes (APÊNDICE E). A 
pesquisa dos dados contidos nos prontuários foi feita manualmente, a partir da revisão de todos os prontuários de clientes existentes nas agendas da especialidade Cardiologia no período supracitado, a fim de selecionar a população com 18 anos ou mais, de ambos os sexos, com diagnóstico de doença arterial coronariana. Cada cliente possui um número de cadastro/registro correspondente a seu prontuário, que encontra-se disponibilizado em arquivos físicos, visando sua utilização.

Para agendamento da visita no domicílio do cliente foi realizado contato telefônico prévio com o cliente; momento em que foi explicado o objetivo da investigação e solicitada a autorização para o encontro, em horários e datas estipulados pelo sujeito.

Atendendo à proposta da pesquisa, todas as entrevistas foram gravadas em gravador microcasssete recorder Panasonic, Modelo n. RN-302 CE, utilizando fitas microcassetes Sony; após explicação da importância deste tipo de registro para a análise dos dados e posterior autorização do cliente para gravar o diálogo.

As entrevistas tiveram duração média de 120 minutos, ocorreram em ambiente domiciliar com seu começo marcado por uma série de fases prévias (como apresentar-se para o sujeito e família e saber suas dificuldades cotidianas); contato que permitiu proximidades entre o pesquisador e família/sujeito no sentido de expressar suas intenções de pesquisa e a marcação de novos encontros. Num primeiro momento, houve receio de falar sobre o assunto, porém uma vez transpostas as distâncias sempre houve acolhimento do sujeito com relação à pesquisadora, manifestando, entre outros aspectos, espontaneidade e cumplicidade na revelação dos dados, nos momentos subseqüentes.

A técnica utilizada para a coleta dos dados foi a entrevista semi-estruturada, empregando um roteiro pré-estabelecido (questionário) com dados relacionados à 
identificação, questões pertinentes ao tema e ao estilo de vida dos clientes. Usamos também a observação participante para coletar os dados sobre o local da pesquisa, bem como para os registros dos próprios sujeitos. Para tanto, nos apropriamos do diário de campo para anotações dos achados.

\subsection{Análise dos dados}

Para realização da análise quantitativa, após a coleta dos dados de identificação, fatores de risco e diagnóstico principal, os dados coletados foram armazenados no sistema gerenciador de dados Microsoft Access 2000 através de uma interface implementada na própria ferramenta.

Para a análise desses dados, implementou-se um sistema de apoio à decisão através da criação de um Data Mart baseado no modelo Star. Efetuaram-se dois cálculos em dados para chegar-se a indicadores como idade e cálculo do índice de massa corporal (IMC). Após a migração dos dados para o Data Mart foi criado um cubo multidimensional, através da ferramenta Microsoft Query e para analisar os dados do Data Mart foi utilizada a ferramenta $O L A P$ do Microsoft Excel XP, de onde foi possível realizar as consultas e extrair dados que compõem as tabelas dispostas nos resultados e discussões. As tabelas são resultantes da análise dos dados a partir de freqüências absolutas e relativas. Os valores de média e desvio-padrão foram obtidos a partir de cálculos realizados pelo programa Excel 2000, da Microsoft.

Após a coleta de dados sobre o tema central, iniciamos a análise qualitativa, quando foram realizadas as transcrições das falas contidas nas gravações, por categorização. As falas foram ouvidas após cada encontro e tiveram seus conteúdos retomados antes das 
transcrições buscando apreender momentos de emoções, reticências, receios, ansiedades; sentimentos que se apresentaram, freqüentemente, durante as entrevistas. As transcrições foram morosas e demandaram uma média de 90 minutos para registro de cada entrevista, gerando um documento de 172 páginas.

Posteriormente aos registros das falas, os relatos foram relidos buscando identificar os temas geradores e selecionar palavras e frases emitidas para ordenar conteúdos dos discursos que ratificassem os temas geradores. Os temas geradores identificados foram: saúde versus doença, medo da morte, fatores de risco, limitações, genitalidade e tabu, submissão, conflitos, dificuldades de relacionamento, preocupação e carências.

$\mathrm{Na}$ segunda etapa foram desenvolvidas as atividades da pesquisa-ação, considerando os temas geradores e a participação da população, utilizando-se da metodologia da problematização. 
7 Resultados e Discussões

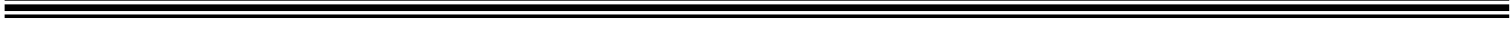




\subsection{Análise quantitativa dos dados}

Conforme preconizado no questionário (Apêndice A), iniciamos a coleta dos dados pela identificação dos sujeitos. A amostra do estudo constituiu-se de 36 sujeitos, sendo 23 $(63,9 \%)$ do sexo feminino e $13(36,1 \%)$ do masculino, com idades compreendidas entre 23 e 86 anos, com predomínio de indivíduos na faixa etária entre 41 a 50 anos (27,8\%); de 61 a 70 anos (25\%) e de 71 a $80(22,3 \%)$, respectivamente (tabela 1$)$. A idade média foi de 56 anos, com desvio padrão de 16,16. Considerando o estado civil dos sujeitos do estudo, a maioria é casada, 23 (63,9\%); seguida de viúvos, 07 (19,4\%), com maior freqüência de mulheres viúvas quando comparados aos homens.

TABELA 1 - DISTRIBUIÇÃO DE SUJEITOS SEGUNDO SEXO E FAIXA ETÁRIA. RIBEIRÃO PRETO, 2007.

\begin{tabular}{ccccccc}
\hline FAIXA ETÁRIA & \multicolumn{3}{c}{ SEXO } & \multicolumn{2}{c}{ TOTAL } & $\%$ \\
\cline { 2 - 5 } $21-30$ & FEMININO & $\%$ & MASCULINO & $\%$ & & \\
$31-40$ & - & - & 02 & 15,3 & 02 & 5,6 \\
$41-50$ & 09 & 39,1 & 01 & 23,1 & 03 & 8,3 \\
$51-60$ & 02 & 8,9 & 01 & 7,7 & 10 & 27,8 \\
$61-70$ & 06 & 26,1 & 03 & 23,1 & 09 & 25,0 \\
$71-80$ & 06 & 26,1 & 02 & 15,3 & 08 & 22,3 \\
$81-90$ & - & - & 01 & 7,7 & 01 & 2,7 \\
\hline TOTAL & 23 & 100 & 13 & 100 & 36 & 100 \\
\hline
\end{tabular}

Estes dados coletados ratificam aqueles descritos na literatura por Azevedo et al. (1991) e Moraes e Santos (1998) quando salientam o aumento da morbidade com a idade; porém observamos que na amostra, contrariando estudos de Veras (1994), Siqueira (2002b) e Silva (2003) houve maior longevidade em indivíduos do sexo masculino, apresentando-se 
com até 86 anos, enquanto os autores anteriormente citados enfatizam que as pessoas do sexo feminino têm tido maior procura e acesso aos serviços de saúde, menor exposição aos fatores de risco para a doença arterial coronariana, além de apresentarem menor taxa de mortalidade em faixas etárias mais elevadas.

Continuando a análise da tabela 1, constatamos a ocorrência de coronariopatias, no sexo masculino, a partir de 23 anos, muito mais precoce do que nos registros da literatura, onde assinala-se a ocorrência da patologia em indivíduos do sexo masculino, principalmente, com idades acima de 55 anos (STAMLER, 1991; BRAUNWALD, 1999).

Esta situação está relacionada ao pior prognóstico cardiovascular em adultos do sexo masculino, de acordo com Brandão et al. (2003b), pois afirma que o sexo vem sendo identificado como fator de risco para a doença isquêmica cardíaca, especialmente em homens com idades inferiores a 50 anos quando apresentam risco três vezes maior que a mulher, na mesma faixa etária, de apresentar infarto do miocárdio.

Ainda examinando a tabela 1 , observamos que na amostra, a coronariopatia iniciase, acima dos 40 anos, na mulher; e se equivale, em termos percentuais, com a ocorrência em homens, nas faixas etárias subseqüentes. Os homens têm maior incidência de doença arterial coronariana em todas as idades, contudo, a diferença de ocorrência entre os sexos reduz com a evolução da idade (VOGELS; LANGRO-JANSSEN; VAN WEEL, 1999). Nesse momento de vida, a partir dos 40 anos, as mulheres tornam-se mais vulneráveis às alterações hormonais e menopausa (MATTHEWS et al., 1989; DANTAS, 1996; KANNEL, 1997; BRAUNWALD, 1999; BRANDÃO et al., 2003b).

Estudos de Vale e Martinez (2000) confirmam a tendência de equivalência da incidência de doenças isquêmicas entre os sexos masculino e feminino, a partir dos 70 anos. Segundo Devon e Zerwic (2003), variáveis como diferenças anatômicas, fisiológicas, 
biológicas e psicossociais podem contribuir para a diferença dos sintomas de AP entre os sexos, mas as pesquisas sugerem que homens e mulheres possuem sintomas similares durante o episódio de angina, porém as mulheres têm diagnóstico de DAC mais tardio, com idade mais avançada quando comparadas aos homens (HOCHMAN et al., 1999); além de apresentarem sintomas típicos da angina de forma mais leve (DEVON; ZERWIC, 2003). A referência quanto ao diagnóstico mais tardio da AP na mulher quando comparada ao homem é confirmada em nosso estudo.

Cabe salientar que, embora haja escassas investigações comparando prognóstico entre homens e mulheres, considerando a mortalidade hospitalar por AP (PASSOS et al., 1999), há inúmeros estudos que mostram maior mortalidade, em mulheres, por IAM; além de pesquisas que constatam a mesma similaridade com o IAM, no sexo feminino, quanto à mortalidade hospitalar por AP instável (GREENLAND et al., 1991; MALACRIDA et al., 1998; PASSOS et al., 1999).

Soto, Juan e Miquel Bañados (1998) ainda assinalam que, em geral, o tratamento para cardiopatias coronárias em mulheres e homens é semelhante, porém há descrições de maior mortalidade de mulheres em relação aos homens nas intervenções terapêuticas destinadas às correções destas patologias (SILVA; NASCIMENTO; VIOTTI JR, 1997); fato que pode estar relacionado aos quadros coronarianos com maior gravidade clínica, pois realizam-se diagnósticos mais tardiamente na mulher que, desta forma, pode ter pior prognóstico.

$\mathrm{Na}$ busca de identificar o IMC dos sujeitos da amostra, na tabela 2, temos a distribuição destes sujeitos segundo o sexo e o índice que apresentam, calculado a partir da divisão do peso (em quilogramas) do indivíduo por sua altura elevada ao quadrado $\left(\mathrm{metros}^{2}\right)$, ou seja, IMC $=$ peso $(\mathrm{Kg}) / \operatorname{altura}^{2}(\mathrm{~m})$. 
TABELA 2 - DISTRIBUIÇÃO DE SUJEITOS SEGUNDO ÍNDICE DE MASSA CORPORAL (IMC) E SEXO. RIBEIRÃO PRETO, 2007.

\begin{tabular}{|c|c|c|c|c|c|c|}
\hline \multirow{2}{*}{$\begin{array}{l}\text { ÍNDICE DE MASSA CORPORAL } \\
\left(\mathrm{Kg} / \mathrm{m}^{2}\right)\end{array}$} & \multicolumn{4}{|c|}{ SEXO } & \multirow[t]{2}{*}{ TOTAL } & \multirow[t]{2}{*}{$\%$} \\
\hline & FEMININO & $\%$ & MASCULINO & $\%$ & & \\
\hline$<25$ (NORMAL) & 03 & 13,0 & 05 & 38,5 & 08 & 22,2 \\
\hline 25 A 27,4 (SOBREPESO) & 07 & 30,5 & 05 & 38,5 & 12 & 33,3 \\
\hline $\begin{array}{l}27,5 \text { A } 29,9 \text { (OBESIDADE GRAU I OU } \\
\text { LEVE) }\end{array}$ & 08 & 34,8 & 03 & 23,0 & 11 & 30,6 \\
\hline $\begin{array}{l}30 \text { A } 39,9 \text { (OBESIDADE GRAU II OU } \\
\text { MODERADA) }\end{array}$ & 05 & 21,7 & - & - & 05 & 13,9 \\
\hline$\geq 40$ (OBESIDADE GRAU III OU GRAVE) & - & - & - & - & - & - \\
\hline TOTAL & 23 & 100 & 13 & 100 & 36 & 100 \\
\hline
\end{tabular}

O peso oscilou entre $50 \mathrm{Kg}$ e $90 \mathrm{Kg}$, com desvio-padrão de 11,16 e média de $75 \mathrm{Kg}$; a altura ficou compreendida entre 1,55m e 1,86m, com desvio-padrão 0,09 e média 1,68m. Considerado como padrão de medida internacional, este índice identifica o grau de obesidade de cada sujeito e, na tabela 2, apresenta-se a classificação do índice de massa corporal de acordo com a International Lipid Information Bureau Latino América (1994). Os índices de massa corpórea acima de $25 \mathrm{Kg} / \mathrm{m}^{2}$ merecem atenção na busca do controle do peso, pois tratam-se de alterações que podem evoluir para graus de obesidade mais graves, e esta doença é um fator de risco para as doenças cardiovasculares (DOREA; LOTUFO, 2001).

A obesidade tem se apresentado como fator de risco para a ocorrência da HAS, assinalando que a prevalência da hipertensão é 2,9 vezes maior em adultos com sobrepeso, subindo para 5,6\% em indivíduos obesos jovens entre 20 e 45 anos (SIVIERO; SCATENA; COSTA JR., 2005).

Estudos de Cassidy et al. (2005) afirmam que a obesidade está associada com a calcificação da artéria coronária traduzindo-se num marcador da presença e extensão da 
aterosclerose coronária subclínica. Na maioria dos casos, a obesidade resulta da associação de vários fatores como genéticos, psicológicos, culturais; além de causas neurológicas e outras como resistência à insulina com hiperinsulinemia (QUAIOTI; ALMEIDA, 2006; LERARIO; LOTTENBERG, 2006).

Da análise dos dados da tabela 2, observamos que apenas $08(22,2 \%)$ dos sujeitos têm IMC, menores que $25 \mathrm{Kg} / \mathrm{m}^{2}$ (faixa de normalidade) e que não há indivíduos com obesidade grau III ou grave em nosso estudo. Cerca de $12(33,3 \%)$ têm sobrepeso e 16 (44,5\% da amostra) já se encontram com obesidade leve e moderada; situação que demanda intervenções no processo de ganho de peso através de orientações nutricionais e programas de atividades físicas supervisionadas por profissionais da saúde, prescritas/recomendadas após avaliação médica criteriosa (SOCIEDADE BRASILEIRA DE HIPERTENSÃO ARTERIAL, 2002; MACEDO et al., 2003).

A atividade física está associada à redução da morbi-mortalidade e, em longo prazo, deve ser considerada nos âmbitos da prevenção primária e secundária. Deve-se ressaltar que durante e após períodos intensos de atividades físicas há aumento do risco para a ocorrência de eventos coronarianos agudos, especialmente em indivíduos com doença arterial pré-existente e sem treinamento físico adequado. As diretrizes atuais recomendam atividades físicas regulares, uma vez que este tipo de movimento traduz-se num fator de proteção e reduz o risco de evento coronariano agudo durante o exercício físico intenso (MÜLLER; NORDHON; WILLICH, 2005).

Evidentemente, faz-se necessária a avaliação do indivíduo antes da participação/realização de atividade físicas para verificar contra-indicações relativas ou absolutas com relação à essa prática, bem como necessidade de supervisão, tipos de 
exercícios possíveis para cada pessoa ou ainda teste ergométrico que determine a prescrição de exercício seguro e individualizado (RACHID, 2000).

TABELA 3 - DISTRIBUIÇÃO DE SUJEITOS SEGUNDO SEXO E NÍVEL DE INSTRUÇÃO. RIBEIRÃO PRETO, 2007.

\begin{tabular}{lcccccc}
\hline NÍVEL DE INSTRUÇÃO & \multicolumn{3}{c}{ SEXO } & TOTAL & $\%$ \\
\cline { 2 - 5 } & \multicolumn{2}{c}{ FEMININO \% } & MASCULINO \% & & \\
\hline ANALFABETO (A) & 03 & 13,0 & - & - & 03 & 8,3 \\
FUNDAMENTAL INCOMPLETO & 10 & 43,5 & 07 & 53,8 & 17 & 47,2 \\
FUNDAMENTAL COMPLETO & 03 & 13,0 & 03 & 23,1 & 06 & 16,7 \\
NÍVEL MÉDIO INCOMPLETO & - & - & - & - & - & - \\
NÍVEL MÉDIO COMPLETO & 05 & 21,7 & 03 & 23,1 & 08 & 22,2 \\
NÍVEL SUPERIOR INCOMPLETO & 01 & 4,4 & - & - & 01 & 2,8 \\
NÍVEL SUPERIOR COMPLETO & 01 & 4,4 & - & - & 01 & 2,8 \\
\hline TOTAL & 23 & 100 & 13 & 100 & 36 & 100 \\
\hline
\end{tabular}

Na tabela 3, verificamos o nível de instrução com relação ao sexo e observamos que os sujeitos analfabetos, em sua totalidade, 03 são do sexo feminino ( $8,3 \%$ da amostra), porém apenas as mulheres apresentam-se, num percentual de 5,4\% dos sujeitos, com acesso ao nível superior.

Há maior freqüência de indivíduos com o nível fundamental incompleto, 17 (47,2\% da amostra); índice que, somado aos percentuais de sujeitos analfabetos $(8,3 \%)$ e com os de fundamental completo $(16,7 \%)$, totalizam $72 \%$ e permite-nos inferir que o nível de escolaridade da amostra é baixo; fato que pode implicar em abordagem educativa minuciosa, detalhada, em face da possível dificuldade para entendimento dos aspectos necessários à sensibilização, minimização e exclusão de possíveis fatores de risco para a ocorrência de coronariopatias. 
Estes achados também nos preocupam, à medida que existem investigações que constatam a ocorrência da DAC variando de acordo com o nível socioeconômico e a associação do baixo nível socioeconômico com aumento relativo de morbidade de AP e IAM, especialmente no sexo feminino (VOGELS; LAGRO-JANSSEN; VAN WELL, 1999); situação que se agrava em nosso estudo ao evidenciamos o número de mulheres analfabetas.

Ressaltamos que o nível de escolaridade, especialmente nas mulheres, tem sido fator importante na ocorrência de fatores de risco para a doença arterial coronariana como sedentarismo, diabetes e obesidade (GIGANTE et al., 2006). A baixa escolaridade, de acordo com Lolio et al. (1990) e Klein et al. (1995), também tem levado à maior incidência de HAS.

Ainda tentando identificar dados socioeconômicos da amostra estudada, verificamos a distribuição de sujeitos considerando sexo e renda familiar, observando que a renda familiar está compreendida entre 01 e 04 salários mínimos (valor vigente do salário-mínimo é de trezentos e cinqüenta reais); com a maioria dos sujeitos, $16(44,5 \%)$ recebendo 02 salários por mês. Notamos também que homens e mulheres têm percentuais de recebimento de salários-mínimos similares, em nossa amostra (tabela 4).

TABELA 4 - DISTRIBUIÇÃO DE SUJEITOS SEGUNDO SEXO E A RENDA FAMILIAR EM SALÁRIOS MÍNIMOS (R\$350,00). RIBEIRÃO PRETO, 2007.

\begin{tabular}{|c|c|c|c|c|c|c|}
\hline \multirow[t]{2}{*}{ RENDA FAMILIAR } & \multicolumn{4}{|c|}{ SEXO } & \multirow[t]{2}{*}{ TOTAL } & \multirow[t]{2}{*}{$\%$} \\
\hline & & $0 \%$ & & $\%$ & & \\
\hline 01 SALÁRIO & 03 & 13,0 & 02 & 15,4 & 05 & 13,9 \\
\hline 1,5 SALÁRIOS & 01 & 4,4 & - & - & 01 & 2,7 \\
\hline 02 SALÁRIOS & 10 & 43,5 & 06 & 46,1 & 16 & 44,5 \\
\hline 03 SALÁRIOS & 05 & 21,7 & 04 & 30,8 & 09 & 25,0 \\
\hline 04 SALÁRIOS & 03 & 13,0 & 01 & 7,7 & 04 & 11,1 \\
\hline NÃO SOUBE REFERIR & 01 & 4,4 & - & - & 01 & 2,8 \\
\hline TOTAL & 23 & 100 & 13 & 100 & 36 & 100 \\
\hline
\end{tabular}


Constatamos que os sujeitos de nosso estudo têm poder aquisitivo baixo e ocupações em estratos inferiores, com rendas baixas, que têm se traduzido em risco independente para a cardiopatia, pois grupos etários assim caracterizados estão expostos à maior morbi-mortalidade por todas as doenças, inclusive em faixas etárias mais jovens e em idosos (BRASIL, 1993; FONSECA et al., 2003; ZAITUNE et al., 2007). O baixo nível socioeconômico de mulheres portadoras de AP foi associado ao hábito de fumar que possuíam, de acordo com Benet (1995).

Investigação de Oliveira et al. (2005) enfatiza que as diferenças sociais no Rio de Janeiro vêm ascendendo e se associam a estudos, no Brasil, que demonstram a relação entre aumento das taxas de mortalidade e baixo nível socioeconômico (SILVA; PAIM; COSTA, 1999), bem como a presença do mesmo quadro nos países desenvolvidos, como os EUA (ROUX et al., 2001). Nesse sentido, compartilhamos com Evans et al. (2001) que há necessidade de intervenções do Estado/Federação, contribuindo com políticas sociais abrangentes pautadas em implementação de saneamento básico e redução de riscos ambientais, universalização da educação e acesso ao emprego, entre outros aspectos que minimizem e protejam contra o empobrecimento evolutivo; além de programas individualizados com foco no controle de fatores de risco para a doença arterial coronariana.

$\mathrm{Na}$ tabela 5, de forma induzida, investigamos quais os fatores de risco para a ocorrência da DAC que estão presentes na vida diária dos sujeitos da pesquisa e que julgam ser possíveis causas para a instalação de seu problema no coração. Estas indagações são fundamentais para averiguar o estilo de vida que os sujeitos adotam, considerando a dieta inadequada; o sedentarismo; uso do tabaco, bebidas alcoólicas e hormônios; se têm diagnóstico de DM e HAS; se possuem ou já tiveram quadros clínicos de 
hipercolesterolemia e obesidade; além de inquiri-los se encontram relações do seu problema no coração com a idade, raça (etnia), história familiar positiva para doenças cardiovasculares e o estresse.

Estes achados, resultantes das respostas dos sujeitos do estudo, também permitemnos avaliar qual o conhecimento/entendimento que possuem sobre os fatores de risco para a doença arterial coronariana e possibilitam refletir sobre o tipo de abordagem e conteúdos a serem discutidos durante a prática educativa; vislumbrando melhor qualidade de vida e saúde, tendo em vista que programas de reabilitação cardíaca focados na modificação/controle dos fatores de risco vêm diminuindo a morbi-mortalidade por DCV (KUNIK, 1994; MANFROI et al., 1998); especialmente quando estes programas se constituem partes de uma política social mais abrangente que culmina em melhores condições de vida da população (OLIVEIRA et al., 2005).

TABELA 5 - DISTRIBUIÇÃO DE SUJEITOS SEGUNDO SEXO E FATORES DE RISCO PRESENTES EM SUAS VIDAS E REFERIDAS COMO POSSÍVEIS CAUSAS DE SEU PROBLEMA NO CORAÇÃO. RIBEIRÃO PRETO, 2007.

\begin{tabular}{|c|c|c|c|c|c|}
\hline \multirow{2}{*}{ CAUSAS } & & \multicolumn{2}{|c|}{ FEMININO } & \multicolumn{2}{|c|}{ MASCULINO } \\
\hline & & $\mathrm{N}^{\mathrm{o}}$ & $\%$ & $\mathrm{~N}^{\circ}$ & $\%$ \\
\hline DIETA INADEQUADA & & 17 & 73,9 & 10 & 76,9 \\
\hline FALTA DE EXERCÍCIO FÍSICO & & 19 & 82,6 & 06 & 46,1 \\
\hline TABAGISMO & & 03 & 13,0 & 10 & 76,9 \\
\hline $\begin{array}{l}\text { INGESTÃO } \\
\text { ÁLCOOL }\end{array}$ & $\mathrm{DE}$ & - & - & 06 & 46,1 \\
\hline ESTRESSE & & 19 & 82,6 & 13 & 100 \\
\hline USO DE ESTRÓGENOS & & 1 & 4,4 & - & - \\
\hline IDADE & & - & - & - & - \\
\hline RAÇA & & - & - & - & - \\
\hline HISTÓRIA FAMILIAR & & 20 & 86,9 & 08 & 61,5 \\
\hline DIABETES MELLITUS & & 09 & 39,1 & - & - \\
\hline HIPERCOLESTEROLEMIA & & 09 & 39,1 & 04 & 30,8 \\
\hline HIPERTENSÃO ARTERIAL & & 21 & 91,3 & 11 & 84,6 \\
\hline OBESIDADE & & 07 & 30,4 & - & - \\
\hline
\end{tabular}


Observamos, ao examinar a tabela 5, que os sujeitos têm algum conhecimento sobre os fatores de risco para a ocorrência do seu problema cardíaco, pois os relacionam com sua patologia, uma vez que referem estar presentes em seu cotidiano; ressaltando-se que homens e mulheres apresentam conhecimentos/referências distintos sobre os fatores de risco citados, excetuando a raça e a idade quando ambos os sexos negam ser fatores de risco para seus problemas no coração.

Ademais, para os sujeitos do sexo feminino, a HAS é referida por 21 (91,3\%) delas; seguida da história familiar, 20 (86,9\%); estresse e falta de exercício físico, 19 (82,6\%), cada fator; dieta inadequada, 17 (73,9\%); DM e hipercolesterolemia, 09 (39,1\%) cada fator; tabagismo, $3(13 \%)$ sujeitos e uso de estrógenos 01 (4,4\%). De forma isolada, excluem de suas vidas e de ser fator de risco para suas doenças cardíacas, a ingestão excessiva de álcool.

Os sujeitos do sexo masculino declararam, com um percentual de $100 \%$, que o estresse está presente em suas vidas, a todo momento, e indicam-no como fator de risco para suas patologias cardíacas; seguido da HAS 11 (84,6\%); dieta inadequada e tabagismo, 10 (76,9\%), cada; história familiar 08 (61,5\%); falta de exercício físico e ingestão excessiva de álcool, 06 (46,1\%) cada e, hipercolesterolemia, 4 (30,8\%) sujeitos. Isoladamente, negam ser fatores de risco para suas patologias o uso de estrógeno e o DM, alegando não usar o hormônio e não ter as duas alterações referidas.

Siviero, Scatena e Costa Junior (2005), numa investigação com 100 clientes infartados, internados em unidade coronariana ou de terapia intensiva de três hospitais gerais de três cidades paulistas, entre 2002 e 2003, encontraram 33 diagnósticos de HAS, 27 de DM, 46 indivíduos fumantes com a população apresentando conhecimento escasso 
sobre colesterol, além da alteração de peso em 81 indivíduos que eram sedentários e tinham história familiar de DAC.

Os fatores de risco apresentados no estudo citado anteriormente, assim como na investigação de Passos et al. (1999), onde a HAS, DM, sedentarismo, tabagismo e história familiar de doenças cardíacas estão presentes, se assemelham aos indicados pelos sujeitos em nossa investigação, bem como àqueles referidos na literatura internacional; mesmo considerando que há interferências de vários aspectos como diferenças entre homens e mulheres quanto à epidemiologia, apresentação e efeitos da DAC; além de diferenças socioeconômicas.

Os fatores de risco indicados pelos sujeitos da amostra são aqueles descritos na literatura e coincidem com dados atuais quando se consideram pesquisas relativas ao quadro epidemiológico e o impacto clínico da HAS - que vem se apresentando altamente prevalente em idosos e tem aumentado o risco de doenças cardiovasculares em todas as faixas etárias (LIBERMAN, 2007).

Consideramos, também, investigações sobre o estresse como fator de risco coronário após evidenciarem que é uma reação do organismo a um estressor com várias conseqüências negativas para a saúde, incluindo o desenvolvimento da aterosclerose, levando a isquemia miocárdica, distúrbio do ritmo cardíaco, estimulação plaquetária e hemoconcentração, bem como disfunção endotelial e vasoconstricção coronária na presença de aterosclerose na artéria coronária (DEVON; ZERWIC, 2003; SANER, 2005).

Constatações nos estudos de Legato (1997) e Théroux (2000) concluem que a depressão e a ansiedade aumentam a morbi-mortalidade em pacientes com doença arterial coronariana, tornando-se fatores de risco independentes para eventos coronários subseqüentes. Na investigação de Pinton et al. (2006), evidenciou-se que pacientes do sexo 
feminino, com idade inferior a 65 anos, apresentaram mais sintomas de depressão durante internações para revascularização do miocárdio; situação que merece constante reavaliação e tratamento, pois pode estar associada a complicações no pós-operatório.

O estresse vem sendo investigado como fator de risco para doença arterial coronariana, desde a segunda metade do século passado, caracterizado como sendo um reflexo do caráter ativo, acelerado, da vida contemporânea (MORALES CALATAYUD, 1991); conforme caracterizado em nosso estudo.

Quanto ao DM, este dificulta o diagnóstico da AP e do IAM (patologias presentes nos sujeitos de nosso estudo), pois mesmo sendo patologias mais freqüentes no portador de diabetes, têm sintomatologias mais sutis (FERNANDES et al., 2000) e, em nossa amostra, apenas as mulheres apresentam o DM como fator de risco, com três delas possuindo a doença. Este dado nos preocupa porque há estudos dos autores supracitados assinalando que aproximadamente $80 \%$ dos adultos diabéticos morrem por DCV e que o risco para cardiopatia coronariana é de 2 duas a quatro vezes maior em diabéticos. Assim, saber sobre a doença e suas conseqüências para o portador de coronariopatias são alternativas para evitar que o diabetes se instale ou ainda tenha controle da patologia, quando já portador de DM.

Fator de risco não modificável, a história familiar para DCV, vem ganhando espaço enquanto indicação da população como fator importante no desencadeamento de doenças cardíacas. Achados de Silva (2003) assinalam que 70,7\% dos sujeitos portadores de AP instável identificaram a história familiar como fator de risco para sua patologia; bem como o aparecimento da história familiar como fator de risco em $61 \%$ dos indivíduos pertencentes à população investigada por Siviero, Scatena e Costa Junior (2005). Este dado é fundamental na medida em que o indivíduo vivencia o cotidiano do familiar acometido 
pela DCV, como relatado em nosso estudo, passando a preocupar-se com alimentação saudável, prática regular de exercício físico e aderência ao tratamento proposto a ele.

O uso do tabaco é referência comum entre os portadores de DAC (SIVIERO; SCATENA; COSTA JUNIOR, 2005), com maior incidência de tabagismo no sexo masculino (DEVON; ZERWIC, 2003; MÜLLER-NORDHORN; WILLICH, 2003); conforme achados de nosso estudo. Os relatos de Muller-Nordhorn e Willich (2003) enfatizam que sujeitos do sexo feminino, após programas de reabilitação cardíaca, atribuem, com maior freqüência, a ocorrência de sua doença coronariana ao tabagismo e história familiar positiva para patologias coronarianas; provavelmente por tomarem ciência de que há maior proporção de mulheres fumantes, após a menopausa, que desenvolvem DCV (VALE; MARTINEZ, 2000; SOCIEDADE BRASILEIRA DE HIPERTENSÃO ARTERIAL, 2002).

O tabaco atua sobre o sistema cardiovascular, causando estímulo adrenérgico, os receptores colinérgicos nicotínicos ativam os gânglios autônomos, ocorrendo a liberação de noradrenalina e adrenalina da medula supra-renal, provocando taquicardia e hipertensão arterial sistêmica, além de vasoconstricção com diminuição da temperatura cutânea e aumento da resistência periférica (STOCCO; BARRETO, 2000; SIMÃO, 2001).

A nicotina também aumenta a capacidade orgânica de formar coágulos e diminui sua função de destruí-lo. O monóxido de carbono resultante da queima do fumo e papel se liga à hemoglobina e reduz o oxigênio nos glóbulos vermelhos em até 20\%; além de lesar a parede interna dos vasos e facilitar o depósito de gorduras nesta área (KLEIN; ARAUJO, 1985; PESSUTO; CARVALHO, 1998). 
TABELA 6 - DISTRIBUIÇÃO DE SUJEITOS SEGUNDO SEXO E DIAGNÓSTICO PRINCIPAL. RIBEIRÃO PRETO, 2007.

\begin{tabular}{|c|c|c|c|c|c|c|}
\hline \multirow[t]{2}{*}{ DIAGNÓSTICO PRINCIPAL } & \multicolumn{4}{|c|}{ SEXO } & \multirow[t]{2}{*}{ TOTAL } & \multirow[t]{2}{*}{$\%$} \\
\hline & $\mathrm{FEl}$ & $\%$ & & $\%$ & & \\
\hline ANGINA PECTORIS & 16 & 69,6 & 6 & 46,2 & 22 & 61,1 \\
\hline INFARTO DO MIOCÁRDIO & 7 & 30,4 & 7 & 53,8 & 14 & 38,9 \\
\hline TOTAL & 23 & 100 & 13 & 100 & 36 & 100 \\
\hline
\end{tabular}

A tabela 6 mostra a distribuição de sujeitos considerando o sexo e o diagnóstico principal, onde identificamos maior número de casos de AP em mulheres, 16 (69,6\%), e de IAM em homens 07 (53,8\%); com 22 sujeitos (61\%) da amostra apresentando diagnóstico principal de AP.

Estas evidências ratificam achados dos estudos de Lolio (1990) e Siqueira (2002a) quando assinalam que a hipertensão arterial é fator de risco para a ocorrência da AP, pois os sujeitos da amostra referem que possuíam HAS antes da instalação de quadros isquêmicos e associam a ocorrência da AP e do IAM ao fato de terem hipertensão arterial. Os autores citados ainda salientam que há aumento da prevalência de quadros isquêmicos com o avanço da idade, especialmente no sexo feminino.

Conforme dados da literatura, a angina instável é conhecida como angina préinfarto, pois cerca de $30 \%$ a $60 \%$ dos indivíduos que sofreram IAM, apresentaram um pródromo deste tipo de angina (BRAUNWALD, 1999; COELHO; UETI, 2000; HATCHETT, 2001).

O prognóstico da angina é determinado pela presença de lesões anatômicas e isquemia nos testes funcionais (RIBEIRO, 2000) e, nesse sentido, depende de fatores como a ocorrência de IAM, recorrência de angina, necessidade de revascularização miocárdica e óbito (SOCIEDADE BRASILEIRA DE CARDIOLOGIA, 2001). 
O percentual de $61 \%$ da amostra apresentando diagnóstico de AP demanda envolvimento da equipe de saúde, no sentido de sensibilizar quanto aos fatores de risco para a DAC, com vistas a minimizar ou evitar recidivas destes quadros anginosos e complicações, como a ocorrência de infarto agudo do miocárdio e óbito.

O IAM apresenta-se como um grande problema de saúde mundial, devido ao número crescente de casos (MARTINS, 2004); além de constituir-se numa das principais causas de morte no mundo ocidental (CARVALHO; MACHADO; MAIA, 2005); manifestando-se principalmente, em indivíduos do sexo masculino (CARDOSO et al., 2005; ESCOBILLANA P. et al., 2006; MARQUEZ ESPINO et al., 2006). Trata-se de uma manifestação clínica causada pela oclusão trombótica de uma artéria coronariana. O infarto normalmente está associado à HAS como fator de risco (ESCOBILLANA P. et al., 2006; BESSER; SILVA; OLIVEIRA, 2006).

\subsection{Análise qualitativa dos dados}

Além da identificação sócio-demográfica da população do estudo, obtida através da abordagem quantitativa, propomos resgatar o entendimento dos sujeitos sobre os aspectos relativos à sua patologia (Apêndice A - Questões sobre o tema central) buscando compreender, qualitativamente, qual o significado de vida que possuem, atualmente, o que pensam sobre o problema no coração, quais os fatores de risco que acreditam ter levado à instalação de sua patologia, as dificuldades que o problema cardíaco representa em suas vidas cotidianas e as implicações da ocorrência dos eventos isquêmicos para sua sexualidade e relacionamentos com o (a) parceiro (a) e família; bem como para sua vida sexual. Este resgate de conceitos/relatos, utilizando a análise qualitativa, possibilita ao sujeito explicitar suas reflexões, sobre seus problemas de vida e saúde, além de propiciar ao 
pesquisador o aprendizado e o compartilhar de novas visões de mundo e do processo saúdedoença, a partir de um entendimento dinâmico das relações sociais.

Ao escutar, observar e se interagir com os sujeitos da pesquisa nos foi possível perceber sua forma de ver, sentir e estar no mundo; conceitos/formas que determinaram suas respostas, seu comportamento/atitude durante a entrevista/diálogo. O gravador foi instrumento para registros falados e possibilitou maior interação com o sujeito por parte do pesquisador, mesmo com o sujeito apresentando certa estranheza com o procedimento e circunstância. Com a gravação dos relatos não houve necessidade de anotação e foi possível dar maior atenção aos sujeitos e, após análise de convergências dos relatos, foram extraídos os temas gerados que seguem.

\subsubsection{Saúde versus Doença}

Ao serem convidados a falar sobre a vida, foram indagados quanto ao seu significado, explicitando coisas/aspectos bons e ruins. Os sujeitos antes de responderem a esta questão, foram reticentes e se apresentaram reflexivos exteriorizando, posteriormente, que tratava-se de uma pergunta muito difícil! "Ah, falar sobre a vida é difícil, a vida é tudo para mim” (sujeito 05, masculino (masc.).

Neste contexto de totalidade/igualdade, os sujeitos indicaram a existência da saúde na família como aspecto positivo e o aparecimento de sua doença como situação negativa. Pautados nestes termos geradores (saúde versus doença), relataram que: “Coisas boas? Coisas boas é que a gente bem ou mal tá com saúde. Eu me considero assim, porque tem gente pior do que eu" (sujeito 11, masc.); "De bom que eu tenho, só meus filhos, com saúde" (sujeito 19, masc.); "Ah, o que eu vou te responder, significado da minha vida é a minha família com saúde, e a gente ter saúde que é o mais importante. E só, ter harmonia 
dentro de casa“ (sujeito 13, feminino (fem.); "Tenho uma vida boa, Graças a Deus. Tenho minha família, meus filhos com saúde, minha casa e meu marido! Mas agora chegou a minha doença!" (sujeito 17, fem.).

Com relação aos aspectos negativos, assinalam que "Hoje o significado da minha vida não vale mais nada. Não vale mais nada, é só doença, só doença” (sujeito 15, fem.); “Coisa ruim é que a gente não tem saúde, né! A gente passa às vezes até dificuldade, problema de remédio porque a gente não tem salário, mas tem as coisas boas" (sujeito 25 , masc.).

A OMS define saúde como completo bem estar físico, mental e social e não apenas ausência de doença; conceito este que nos remete a uma idéia de saúde inatingível, visto que viver em estado de mudanças é comum e, para alcançar todas as vertentes de saúde ótima, teríamos de ocupar um “estado estável” (BUENO, 1991; SEGRE; FERRAZ, 1997; ABREU et al., 2007). Assim, o conceito de saúde deve ser dinâmico, construído por cada indivíduo e a sociedade, de acordo com suas condições de vida e a interação que conseguem com elas; como declara o sujeito: "Coisas boas? Coisas boas é que a gente bem ou mal tá com saúde. Eu me considero assim porque tem gente pior do que eu. E tenho meus filhos perfeitos" (sujeito 11, masc.).

Para Laurell (1982), há dois conceitos de doença que se fundem; o conceito médicoclínico (doença é um processo biológico do indivíduo) e o ecológico (a doença é resultado do desequilíbrio na interação do hóspede e seu ambiente). Conceituar a doença e a saúde são aspectos fundamentais para compreender o caráter social do processo saúde-doença.

A concepção de saúde-doença é resultado de formas de viver de cada ser humano, durante seu processo de existência. Assim, sofre influência da visão criada, no decorrer da 
vida, sobre como transformar e interferir na realidade cotidiana, com relação ao trabalho, saúde, doença, entre outros fatores (FRACOLLI; BERTOLOZZI, 2001).

As autoras supracitadas ainda salientam que a concepção mais integral sobre o processo saúde-doença fundamenta-se na Teoria da Determinação Social do processo saúde-doença e assinalam que saúde e doença compõem momentos de um processo maior que se refere à vida das pessoas que, por sua vez, está intrinsecamente ligada ao potencial que elas têm com relação ao acesso às situações para viver a vida; seja a saúde, a educação, o lazer.

Esta teoria vem de encontro com a relação que os sujeitos do estudo fazem ao associar saúde como o que possuem de melhor na vida "Ter saúde é tudo de bom na vida!" (sujeito 31, fem.); e ainda ao comentar que a doença é algo ruim,

[...] A única coisa, a parte que eu acho dificuldade, é a gente querer, precisar de uma coisa e não tem, no caso da saúde! A gente que nem eu, eu pago o INSS, na hora que eu preciso eu não tenho médico, eu não tenho nada. Eu precisei de um exame da esteira, eu tive que pagar, porque eu não consegui. Então eu acho que a outra parte ruim é isso daí. Um direito que a gente tem e não tem (sujeito 36, fem.).

Constatamos, pelas falas dos sujeitos, que a saúde é seu "bem" maior e que na presença da doença ficam desprovidos de direitos, pois o lugar que ocupam na sociedade neste momento, como enfermos, não os confere a possibilidade de serem assistidos. Nesse sentido, a vida humana oferece processos que protegem as pessoas, bem como aqueles que lhes causam danos; uma vez que, em vários momentos da vida há oscilações entre "fortalecimento e desgaste do corpo humano"; processo manifestado através do estado de saúde ou de doença, respectivamente (SEGRE; FERRAZ, 1997).

Os indivíduos de ambos os sexos apresentaram respostas semelhantes ao falarem sobre as suas vidas e pontuarem aspectos positivos e negativos sobre ela. 


\subsubsection{Medo da morte}

O coração, desde a antiguidade, é considerado um símbolo de vida, um órgão central para a existência do ser humano, seja para representar condições afetivas ou ainda o espírito humano. Desta forma, compartilhamos das referências de Soares e Moreira (2006) quando assinalam que o coração é "o motor da existência".

A partir deste significado do coração na vida das pessoas são comuns referências de portadores de cardiopatias quanto ao medo da morte (BITTAR, 1992; SOARES; MOREIRA, 2006), em função do acometimento abrupto, súbito e da impotência diante da forma com que este evento se manifesta.

Durante o diálogo com os sujeitos deste estudo houve declarações que corroboram estes achados da literatura, como "Não, eu às vezes me preocupo de medo de morrer, que às vezes pode dar uma dor forte e eu não agüentar e eu vou pro chão" (sujeito 09, masc.). “Tomo remédio. Me cuido. Com muito medo. Medo de morrer" (sujeito 21, fem.). Ribeiro (1994) afirma que as pessoas se negam a falar sobre a morte, discurso reforçado por Ferrão (2003), quando ainda acrescenta que a morte representa a finitude do processo vital; caracterizando-se como um fracasso do ser humano, mas Boemer (1986) comenta que ela deve ser entendida como parte da existência humana.

De acordo com Kovács (1992), o medo de morrer é universal; assim, atinge os seres humanos em sua totalidade de forma igualitária, e se apresenta como a resposta psicológica mais comum em seu estudo sobre a morte. A morte significa a interrupção desta existência humana; que para os sujeitos de nossa amostra representa a perda do seu objeto de maior valor, especialmente pela separação de suas famílias e seus filhos; ou seja, a perda de seu papel em todos os âmbitos da sociedade em que vive (HONS, 1997; SOARES; MOREIRA, 2006). Esta situação é reiterada pelos sujeitos do estudo quando dizem que "Eu fíco 
aborrecida sabe, porque sei lá, eu tenho muita vontade de viver, e eu tenho medo de uma hora pra outra a gente ir embora e deixar família, e eles dependem muito de mim” (sujeito 13, fem.); "O que eu penso, eu tenho medo, por exemplo, de uma hora dar essa dor e eu não agüentar e morrer e largar minha filha pequena. Minha preocupação é essa" (sujeito 14, fem.).

Associados à circunstância supracitada, convivemos com dados referentes ao aumento do número de mortes por DCV, pois estes têm sido disponibilizados, com maior ênfase na mídia escrita e falada; além do fato de estar se tornando comum ter ciência ou vivenciar a morte súbita de pessoas por IAM na comunidade. Tais situações têm reforçado o medo de morrer naqueles cidadãos que são portadores de coronariopatias, que independente do sexo, vêm se apresentando assustados diante desta situação; ressaltando que a mulher preocupa-se mais com a separação da família e o homem com a perda de sua própria vida.

$\mathrm{Na}$ verdade, diante da possibilidade de morrer, surgem os períodos dos medos: da dor, da piora da situação clínica, do abandono e da morte propriamente dita, conforme ressalta Hons (1997); instalam-se questionamentos acerca de "questões fundamentais do sentido da vida". Mas também existem sujeitos que dizem não pensar sobre o assunto, “Ah..., eu num penso não, num penso o porquê deu isso, e num penso também porque, eu não sou a primeira e nem a última, tem tanta gente com doença de coração. Num dá tempo de ficar encucando, né! O porquê que eu vou pensar, porque que foi..., né!” (sujeito 28, fem.); "Não, eu não, não paro pra pensar sobre isso não. Você sabe que eu não paro pra pensar nem na minha pressão. Eu, às vezes, eu falo assim, eu tô ruim! Não, não tá ruim, vou fazer aquilo, não, não posso fazer!” (sujeito 02, fem.). 
Estas declarações denotam conformismo e fuga, respectivamente; sentidos comuns aos portadores de doenças graves ou de portadores de patologias do coração (SOARES; MOREIRA, 2006).

\subsubsection{Fatores de risco}

Após terem expressado o que pensavam sobre seu problema cardíaco, os sujeitos foram indagados quanto ao que acreditavam ser as possíveis causas para a ocorrência da referida patologia e predominaram os fatores de risco para a DAC, como indicações.

Inúmeras investigações vêm ocorrendo na busca de identificar os fatores de risco para a DAC nas populações, vislumbrando estratégias que possam minimizar ou ainda excluí-los gerando decréscimos da morbi-mortalidade por esta doença; através de prevenção primária e secundária.

Os achados da literatura indicam como fatores de risco mais comuns para a DAC a idade, o DM, a ansiedade e depressão, HAS, dislipidemia, sedentarismo, tabagismo e história familiar positiva para DAC, obesidade (FORTI et al., 1996; PASSOS et al., 1999; GUS; FISHMAN; MEDINA, 2002; DEVON; ZERWIC, 2003; SIVIERO; SCATENA; COSTA JR, 2005; LIBERMAN, 2007; MAIA et al., 2007).

Em nosso estudo foram considerados como causas, a partir de indicações espontâneas, para o problema cardíaco: o estresse manifestado, principalmente, por ansiedade e preocupações; HAS, tabagismo e obesidade.

O estresse é a reação do organismo frente a um agente estressor; momento que o ser humano redistribui suas energias para atender à situação de "perigo iminente" (LOURES et al., 2002; SANER, 2005), conforme relatam os sujeitos da amostra, 
[...] Olha esse dia que me deu essa dor no peito, no coração, eu estava muito estressada, tava nervosa com problema com a minha filha... ai por causa de desobediência. Já faz uns 6 meses mais ou menos, aí eu tava muito com pensamento nos problemas dela, aí quando que eu tava costurando, minha irmã tava aqui sentada ainda, costurando, veio aquela dor forte! Hora que deu aquela dor forte parei de costurar e larguei tudo, fiquei quieta. Aí daí o pouco deu outra dor bem forte mesmo e eu dei aquele grito, e ela viu do jeito que eu fiquei; tava até minha cunhada junto; eu murchei tudo, fiquei murcha, aí foi no postinho e mediu minha pressão e tava alta. Aí a moça do postinho me mandou ir para o hospital lá embaixo (sujeito 08 , fem.);

[...] Sabe, você quer uma coisa certa e as coisas nunca tá do jeito que você quer, sempre torce pra um lado errado, principalmente quando é filho, mas eu sei o que tá acontecendo, então isso vai te remoendo por dentro, ao invés de conversar a gente briga. $\mathrm{E}$ a violência sabe, porque ela vem em cima (sujeito 03 , fem.).

Embora ainda haja resistência da comunidade científica, recentemente, o estresse vem se firmando como fator de risco para a doença arterial coronariana (ENGEL, 1971; KAMARCK; JENNINGS, 1991). Hoje, as investigações priorizam a interpretação subjetiva do estresse e suas repercussões nos seres humanos (LOURES et al., 2002; BALLONE, 2003). Cada pessoa classifica e reconhece seu conflito e responde com ansiedade, depressão, isolamento social ou estresse crônico; conforme salientam Ballone (2003) e Saner (2005).

Os relatos dos sujeitos estudados ratificam a manifestação da ansiedade como fator de risco quando salientam “Ah, às vezes é preocupação, né! Porque a gente tem família grande, e a gente tá sempre preocupada com as coisas. Sou nervosa, às vezes querendo alguma coisa e não conseguindo ter aquela coisa que a gente sempre quer, né” (sujeito 12, fem.).

[...] Olha esse dia que me deu essa dor no peito, no coração, eu estava muito estressada, tava nervosa com problema com a minha filha, aí por causa de desobediência. Já faz uns 6 meses mais ou menos, aí eu tava muito com pensamento nos problemas dela, aí quando que eu tava costurando, minha irmã tava aqui sentada ainda costurando veio aquela dor forte, hora que deu aquela dor forte parei de costurar e larguei tudo, fiquei quieta, aí foi no postinho e mediu minha pressão e tava alta (sujeito 08 , fem.). 
Ainda assinalaram estarem vivendo situação de tristeza/depressão como,

[...] Olha, isso foi choque, choque né, acidente, ele já tem nome de acidente; vê o tanto que ele é chocante, e ainda nesse foram duas pessoas de casa, dois sobrinhos na mesma idade. Faz 13 anos. Os dois saíram para passear e me chega num caixão lacrado. Isso é pra te deixar em choque, se isso não te deixa em choque, o que te deixa? Nada, nada. Nunca tinha tomado um comprimido para pressão. Você sabe que o remédio que eu tomei foi de gravidez que você faz um pré-natal, quando tive filho e precisei cesárea que você toma antibiótico, e só! (sujeito 02, fem.);

[...] Eu acho que é muita perda, né. Eu perdi minha mãe, logo perdi meu marido que foi embora com outra, isso acabou com a minha vida. Fiquei com os filhos, vim pra aqui e não conhecia ninguém; depois fiquei lutando com a doença do meu pai muito tempo, logo perdi ele também. Então, sabe, e depois que eu perdi meu pai eu passei tão mal com essa dor no peito que pensei que ia morrer (sujeito 04, fem.).

Estudos vêm demonstrando que a ansiedade e a depressão aumentam a morbimortalidade em pacientes com DAC, sendo que ambos têm se manifestado após o episódio do infarto do miocárdio, segundo Théroux (2000) e Schleifer et al. (1989).

Em nossa amostra, estes sentimentos emocionais foram relatados como tendo ocorrido antes dos eventos isquêmicos, como nas investigações de Morales Calatayud (1991); dados que corroboram estudos recentes, onde a depressão e a ansiedade são fatores de risco para o desenvolvimento da DAC e também aumentam a mortalidade na vigência destes sentimentos, após episódio de IAM (FRASURE-SMITH; LESPÉRANCA; TALAJIC, 1995; BALLONE, 2003).

A HAS foi identificada como fator de risco pelos sujeitos do estudo porque além de possuí-la antes do evento isquêmico de forma crônica, houve agudização do quadro hipertensivo nos momentos que antecederam os episódios de infarto agudo e da angina, conforme relato a seguir: "Acho que tem a ver com minha vida agitada! Trabalho muito, sou ansiosa e já tenho P.A. alta! (sujeito 03, fem.)" 
[...] Fui no postinho e mediu minha pressão e tava alta. Eu fui no hospitalzinho, chegando lá, a médica me consultou, mediu minha pressão, já tava 16 x 13, aí a médica atendeu eu e falou que isso aí foi um pico que deu no coração, um pico, agora esse pico eu não sei o que significa, e vou te encaminhar para o cardiologista pra nós ver o que está acontecendo. Aí inclusive passei com o cardiologista, ele fez todos os exames que tinha que fazer, e ele falou assim que ele ta anormal, meu coração, quer dizer que não ta normal né. Essa dor que deu foi que nem começo de enfarto (sujeito 01, fem.);

[...] Não, eu nem pensava que era isso, porque dor de estômago, pelo que vejo falar, dor de infarto é no peito né, em cima, que vejo falar, e a minha num foi, a minha foi no estômago, e então eu pensava que era coisa do estômago né; mas daí fomos ver e num era. Era infarte mesmo (sujeito 10, masc.).

A HAS tem se apresentado como fator de risco para a doença arterial coronariana e vem se mantendo com altas prevalências na população mundial (DEVON; ZERWIC, 2003; SIVIERO; SCATENA; COSTA JR, 2005); principalmente entre os idosos (BRAUNWALD, 1999; LIBERMAN, 2007). Tem caráter multifatorial; fato que dificulta a definição de sua etiologia (BALLONE; 2003); com a maioria dos casos sendo classificados como de hipertensão arterial essencial. Mesmo apresentando esta complexidade quanto ao mecanismo fisiopatológico, a hipertensão arterial é de fácil diagnóstico e há, no mercado, terapêutica para seu controle (CASTRO ROLIM; MAURÍCIO, 2005). Ressalta-se a importância de manter e controlar níveis tensionais dentro de parâmetros normais, abaixo de $140 \times 90 \mathrm{mmHg}$.

Um sujeito apontou o cigarro que usa, desde a adolescência, como causa, assinalando: "Tudo na minha vida! O cigarro... fumava como se fosse comida!" (sujeito 22, masc.) Dados da literatura ratificam esta indicação quando assinalam maior prevalência de tabagistas entre os indivíduos que possuem DAC (MANFROI et al., 1998; PASSOS et al., 1999; DEVON; ZERWIC, 2003; DUARTE et al., 2007); bem como aumento significativo da pressão arterial em pessoas fumantes (RODRIGUEZ PERÓN et al., 2004). 
Embora já existam vários estudos e programas de ajuda aos fumantes e a percentagem de tabagistas venha diminuindo quando se compara a inquéritos anteriores (MARCOPITO et al., 2005); a orientação deve ser no caminho da estimulação para deixar o hábito.

A obesidade foi indicada na fala do sujeito 16 “Ah, sente cansaço, é suor...assim sabe, eu penso que eu tô gorda, eu me vejo que eu já tô assim, passando do meu peso normal, né" (sujeito 16); confirmando achados de Cassidy et al. (2005), bem como relatos de Smanio e Mastrocolla (2005), que apontam a obesidade como fator de risco para a doença aterosclerótica; adquirindo, em determinados locais, caráter epidêmico, de acordo com Lerário e Lottenberg (2006); quadro este que pode ser explicado devido a comportamentos e alimentação inadequados.

Sugerimos que os esforços para controle da obesidade sejam nos âmbitos de tratamento e prevenção da doença, considerando exercícios físicos regulares; além da adequação a hábitos alimentares saudáveis; pois as perdas de peso, mesmo discretas, aliadas a exercícios físicos regulares são ações efetivas na redução de fatores de risco para a DAC, conforme salienta Santos (2006). O exercício físico regular nos coronariopatas, segundo Costa (2000), promove adaptações que elevam o limiar de isquemia miocárdica; diminui arritmias ventriculares durante a atividade e, conseqüentemente, a incidência de morte súbita; melhora a qualidade de vida e o prognóstico dos portadores da doença.

Para a indicação/prescrição da atividade física são necessários a realização cuidadosa história clínica e exame físico, tentando diagnosticar instabilidade clínica recente e possível obstrução grave em segmentos de saída ventricular (RACHID, 2000). Assim, a prescrição, supervisão médica e o grau de monitorização durante o exercício deverão ser individualizados. 
As respostas dos sujeitos entrevistados apontando os fatores de risco para a doença arterial coronariana como causas para seus problemas cardíacos coincidem com aqueles descritos na literatura nacional e internacional.

\subsubsection{Limitações}

Uma vez apontadas as possíveis causas para a ocorrência de sua doença cardíaca, os sujeitos pontuaram as maiores dificuldades que encontram, atualmente, frente ao seu problema no coração e, enfaticamente, indicaram as limitações que a doença impõe. Estas limitações ocorrem no âmbito social (dificuldade financeira para manutenção do tratamento), física (manifestação da dor torácica e do cansaço na vigência ou não de esforço físico) e emocional (medo de morrer).

As limitações sociais são reconhecidas na literatura em trabalhos como de Silva (2003), que caracteriza o difícil acesso ao sistema saúde coletiva seja para agendamento de consultas, realização de exames, aquisição de drogas para a terapêutica, ausência de leitos para internação; além da escassez de trabalhos na prevenção primária, a partir de políticas públicas que considerem o caráter individual e coletivo da população. O tempo de espera para atendimento eletivo no ambulatório de cardiologia de referência no estudo é de 20 dias e, uma vez solicitados exames de alta complexidade, é necessário aguardar agendamento que ocorre através da central de regulação de vagas, com tempo de espera de cerca de 12 meses (01 ano).

A rede de atendimento dos usuários do Sistema Único de Saúde (SUS) disponibiliza as drogas que são preconizadas nos programas de saúde instituídos pelo governo federal; terapêutica nem sempre prescrita e, por isso, muitas vezes os sujeitos são obrigados a comprar ou adquirir com recursos próprios outros tipos de drogas prescritas/necessárias: "Eu compro. Gasto, gasto muito. Em relação uns quinhentos e poucos, por mês” (sujeito 06, fem.); 
[..] Não poder fazer tudo que preciso, que quero fazer, e também a dificuldade para conseguir comprar o remédio porque meu remédio não tem no posto! Ganho pouco e a minha família não tem ganhos para dar conta de pagar. Às vezes fico sem o remédio (sujeito 36 , masc.).

Há pessoas aposentadas e que recebem pensão alimentícia que priorizam a compra dos remédios em face do pagamento de gastos diários com moradia, por exemplo, como relata "Ah, problema de..., contas pra acertar. Nosso salário... do senhor Lula” (sujeito 29, masc.); “Sou pensionista. É uma pensão, não tá dando pra comprar meus remédios. É 650/700 conto de remédio todo mês! Caro! E pra pegar na prefeitura tá meio difícil. Tá, tá complicado" (sujeito 31, fem.).

Esta situação, muitas vezes leva os sujeitos a questionarem como dar continuidade ao tratamento de saúde, pois conforme relatos, usam algumas drogas associadas para a terapêutica das síndromes isquêmicas miocárdicas, conforme preconizam as Diretrizes da Sociedade Brasileira de Cardiologia; a saber, antisquêmicos, betabloqueadores e antitrombolíticos.

Diante do baixo nível socioeconômico e cultural e do valor elevado do tratamento proposto ao portador de coronariopatias, conforme salienta o sujeito "A maior dificuldade é... eu luto contra pra poder ter meu dia a dia normal e às vezes até esqueço, sabe? Mas não é fácil esse tanto de remédio que a gente tem que tomar (sujeito 33, fem.)". Observamos a impotência de cada cidadão para garantir sua cidadania; mesmo com o advento da disponibilização de medicamentos genéricos, uma vez que este tipo de apresentação ainda existe em número limitado de classes farmacológicas e há medicamentos, nesta apresentação, com custo reduzido em até 300\% do valor de cada comprimido. Em agosto de 2007 o Captopril 25 mg, por exemplo, apresentação genérica, de 30 comprimidos, tem valor de $\mathrm{R} \$ 13,60$ a caixa, sendo o valor unitário do comprimido $\mathrm{R} \$ 0,45$ centavos de real; 
Capoten $25 \mathrm{mg}$ - apresentação comercial, caixa com 28 comprimidos; valor da caixa $\mathrm{R} \$ 33,90$ e valor do comprimido é de $\mathrm{R} \$ 1,21$ por unidade. Estas comparações expressam a evidência da necessidade de disponibilização maior do número de classes farmacológicas padronizadas pelos serviços públicos de saúde, para utilização da população no tratamento, neste caso, das coronariopatias.

Os sujeitos também assinalam as limitações físicas "Ah, eu me sinto muito cansada" (sujeito 03, fem.); "Sou aposentada. Só queria fazer as minhas tarefas do dia, mas fico cansada" (sujeito 35, fem.); "Sou aposentado e vivo da renda que ela me dá, não tenho dificuldade para andar de bicicleta, sabe! Moro sozinho, é... a casa fica suja; porque fico cansado quando começo a limpar" (sujeito 07, masc.).

A isquemia miocárdica se manifesta, clinicamente pela dor torácica que ocorre principalmente em momentos de maior consumo de oxigênio, como em exercícios ou ainda por diminuição da oferta em função, por exemplo, da obstrução por estreitamento da luz arterial decorrente da aterosclerose (HURST, 1990; BRAUNWALD, 1999). De acordo com Braunwald (2001) e Mano (2004), desconsiderando exames complementares, a dor anginosa deve ter características típicas de angina, com diagnóstico de síndrome coronariana aguda. A dor anginosa caracteriza-se por dor opressiva ou queixa/pressão na região precordial ou retroesternal, podendo irradiar-se para a região cervical medial do membro superior esquerdo, ombro, mandíbula, dentes, pescoço e costelas. As crises de dor são intermitentes, com duração de 3 a 5 minutos, tem seu início ou piora na vigência de esforços ou estresse, e melhora com repouso e utilização de nitratos (BRAUNWALD, 1999; RIBEIRO, 2000). 
Os sujeitos declararam cansaço, especialmente, diante de esforços, que se apresenta, desproporcional à ação que está sendo executada; dado que pode ser considerado como equivalente da dor torácica, denominado equivalente anginoso (BRAUNWALD, 2001; MANO, 2004).

A manifestação destes sintomas de ordem física e a dificuldade para seguir o tratamento indicado têm levado os portadores de coronariopatias a outro tipo de limitação, a emocional; situação manifestada quando se sente culpado/responsável pela sua doença (SOARES; MOREIRA, 2006).

Diante da dificuldade de continuar o tratamento (devido ao baixo poder aquisitivo) e com a sintomatologia da doença em vigência, manifesta-se o conflito da possibilidade de complicação do quadro patológico em função da não realização da terapêutica, e conseqüentemente, o medo de ficar mais doente e o medo da morte, ilustrado nas falas dos sujeitos: "Me põe de castigo. Ando pouco (perto das minhas atividades de antes), não fumo mais, sei que faz mal, mas eu gostava porque me distraía. Hoje posso muito pouco!" (sujeito 08 , fem.); “Ah, traz muita tristeza, medo das doenças, medo de ficar doente sozinha dentro da casa, eu tenho muito medo, e... eu vou ao médico, e ele me pede pra fazer esteira né, e num consigo fazer" (sujeito 12, fem.).

[...] Dificuldade, é muito medo que eu tenho. Eu tenho medo de ir no médico, ói, eu tenho medo de morrer, medo de ir no médico .....medo até de ver o resultado do exame, né! Nossa se tenho! Tenho medo de, ah, preocupação, esquenta a cabeça (sujeito 18, fem.).

O cliente portador de cardiopatias, de acordo com Lamosa (1990), deve ser tratado de forma a considerar o simbolismo que o órgão possui para as pessoas, é visto como a fonte de vida. Frente ao diagnóstico da coronariopatia o sujeito mostra fragilidade e sofre o 
estigma de ser um "doente do coração"; situação que se agrava quando o próprio indivíduo se sente inseguro, como ocorre em nosso estudo, com relação a uma complicação ou quando se sente culpado/responsável pela sua doença (SOARES; MOREIRA, 2006). Na fala do sujeito, evidencia-se essa última citação: "Então, como eu falei! Sempre fico muito nervoso, ansioso, sabe!... Daí fumava muito....03 maços por dia! Comia cigarro com farinha! Dormia pouco!"” (sujeito 07, masc.).

Diante da doença, considerada grave, por todo o simbolismo que o coração possui para o ser humano, os sujeitos deste estudo vêem-se diante da perda de seu equilíbrio vital e enxergam uma série de perdas, sucessivamente, sem conseguir reagir devido, entre outros aspectos, às limitações financeiras e físicas; confrontando-se com a possibilidade da morte, conforme salienta Hons (1997), e descobrindo a precariedade de sua existência.

Considerando os relatos dos sujeitos as limitações sociais, físicas e emocionais ocorrem em ambos os sexos, com maior indicação destas limitações sendo referidas pelas mulheres.

\subsubsection{Genitalidade}

\subsubsection{Tabu}

Mesmo diante de reflexões acerca da existência, buscamos resgatar pontos/focos de qualidade de vida, nesta trajetória. Dentre diversos aspectos que poderiam ter sido considerados, optamos por resgatar os conflitos de sua sexualidade como portadores de coronariopatias. Os questionamentos foram realizados de forma a tentar captar entendimento dos sujeitos da amostra a partir de uma visão ampliada de sexualidade e sexo, enquanto elementos para melhorar a qualidade de vida, seguido da concepção de vida saudável, relacionamento com o parceiro e família; num contexto mais micro. 
A sexualidade, segundo Papaléo Neto (1996), é definida como a maneira de uma pessoa expressar seu sexo, ou seja, através de sua forma de vestir, de andar, de falar, de sua postura; enfim, através de suas especificidades, de seu jeito de ser. Desta forma, a sexualidade é vivenciada de acordo com a cultura que se tem, que se cria (BRUNS; ALMEIDA, 1994), de um modo individual (LYRA; JESUS, 2007).

A sexualidade foi conceituada como sexo, aqui definido como o ato sexual pelos sujeitos da amostra, de acordo com as declarações:

[...] Eu acho que não é diferente porque, eu não sei se é, sexualidade quer dizer... é um pouco do sexo também.. só que eu não sei se é, assim quando a pessoa quer muito... fica naquela coisa, aquela ... tá entendendo? E eu não sei se é isso. Sexo é ficar junto com a outra pessoa fazendo, tendo relação sexual! É a mesma coisa, né? (sujeito 32, fem.)

[...] Primeiro é que tem o feminino e o masculino, né? O sexo influencia na sexualidade pra gente ter um bom relacionamento eu acho que a gente tem que estar com a parte sexual da gente toda em dia, a parte ginecológica, pra gente ter nossa sexualidade resolvida (sujeito 20, fem.).

Nossos sujeitos, como no estudo de Lyra e Jesus (2007), entenderam que sexo e sexualidade são sinônimos, com a conotação da relação/ato sexual focado no órgão sexual, no coito. O equívoco dos sujeitos, de ambos os sexos, está na visão limitada do entendimento de sexualidade, pois o coito é apenas um dos aspectos; a sexualidade está nas nossas vidas, em todas as fases de nossas manifestações vitais. A sexualidade, de acordo com Bernardi (1985), “indica uma propensão humana que envolve a vida inteira, já a genitalidade é uma atividade concreta e física da sexualidade", que utiliza os órgãos genitais para sua realização. Em suma, concluimos que a sexualidade pode se manifestar sem que haja genitalidade; através de abraços, beijos, sonhos e percepções vitais, por exemplo. 
Costa et al. (2001) salientam que a sexualidade associa-se à história de vida, valores culturais e aspectos afetivos, enquanto a genitalidade liga-se apenas a aspectos biológicos.

Violante (2003), comentando Freud, na visão psicanalítica, enfatiza que a sexualidade não se restringe à genitalidade e abrange, inclusive, um fator psíquico onde a libido é parte constituinte.

Nesse sentido, alguns sujeitos manifestaram seu conhecimento sobre sua sexualidade referindo "Era desejar minha esposa....achar ela gostosa..." (sujeito 29, masc.); “Sexualidade é uma situação gostosa de sentir, uma coisa que vem de dentro! É estar bem!" (sujeito 32, fem.); “Ai meu Deus, o que que é sexualidade? Ah, assim, é a gente estar em forma com o corpo, é uma coisa que eu acho que é isso" (sujeito 16, masc.).

Estes indivíduos citados acima parecem possuir um conceito mais abrangente de sexualidade, encontrando-a em outras dimensões do viver, além da genitalidade.

Ainda observamos que vários sujeitos ficaram envergonhados/nervosos ao falar sobre o assunto e em alguns momentos constatamos a interferência da cultura e da religião na concepção de sexualidade e sexo; situações evidenciadas nas falas de:

[...] Não sei não! Tenho pouco estudo! Eu acho que tudo tem a hora certa, né! Tudo vem de coisas bem pensadas, programadas, e isso é um tipo de outra coisa que só traz problema, mas não vou condenar (sujeito 22, masc.).

[...\} Falar não! Daquele passado lá não! Não, não! Ah, então, também não sei explicar. É daquele tempo também! Não se falava sobre isso também não. Não sei te dizer, não, filha! Nunca me falaram disso! (sujeito 34, fem.)

Os relatos supracitados foram ditos na forma de negação, com os sujeitos se manifestando agitados, com olhares baixos, vozes trêmulas, mãos que se esfregavam constantemente e cabeças que giravam de um lado para o outro; estas atividades expressam a importância de entendermos a sexualidade de acordo com a cultura e o modo de viver de 
cada um, não se tratando de atitudes/sentimentos universais, pois a forma que cada um vivencia sua sexualidade, desde a infância, interfere na construção de sua identidade sexual e no modo como trata o assunto em casa (COSTA et al., 2001).

Nestes momentos de vida é que se faz necessária a educação e/ou orientação sexual por parte da família e de educadores escolares e de saúde, num movimento conjunto que privilegie a autonomia e o protagonismo dos indivíduos, a partir de informações que possam estimular reflexões futuras na caminhada em busca da maturidade. A informação sexual é um instrumento de grande relevância para a qualidade de vida e deve ser discutida com respostas diretas para prevenir conceitos errôneos e impressões falsas.

Jaramillo Vélez e Uribe Jaramillo (1996) salientam que, em estudo com jovens em Medelin, confrontaram-se com conceitos de sexualidade impregnados de genitalidade, mistério e medo, num contexto onde havia falta de diálogo, concepção biológica e genital acerca da sexualidade e confusões sexuais; pontos que propiciam esteriótipos de gênero e certa resistência para o desenvolvimento e produção de novos saberes sexuais.

Freud, no início do século XX, num contexto no qual a sexualidade era tema vergonhoso, estimulou as pessoas a observar a presença do sexo nas relações diárias e no desenvolvimento da personalidade, concordando com argumentações de Abdo (2004), que a sexualidade é um dos principais pólos estruturantes de nossa identidade e nossa personalidade; mas apesar de ser natural, tem seu aspecto erótico envolvido por mitos, tabus e preconceitos; sentimentos que mudam ao longo da história e de acordo com a

\subsubsection{Submissão}

Para o resgate dos conflitos da sexualidade do portador de coronariopatias perguntamos como era sua vida sexual, antes da ocorrência da doença, e as respostas 
assinalaram a submissão da mulher/esposa em relação ao homem/esposo. O diálogo, nesse momento da entrevista, voltou a ficar pausado e hesitante; principalmente quando os relatos eram de sujeitos do sexo feminino, pois se apresentavam nervosas e ansiosas, porém com o discurso de que tudo era comum, com ressalvas posteriores: "Normal. Fazia quando tinha vontade! Quer dizer... quando meu marido tinha vontade" (sujeito 33, fem.); "Não, não era aquelas coisas, mas era o dever de marido e mulher" (sujeito 12, fem.); "Não, a moda do outro, toda época que precisasse, que procurava, tinha!” (sujeito 02, fem.). Nas falas acima ficou clara a submissão da mulher com relação a "servir" sexualmente o homem.

O gênero é um produto social e acompanha a história, ilustra-se no estudo de Lyra e Jesus (2007), quando citam a influência dos conceitos existentes nas civilizações judaicacristã e greco-romana, onde havia grande repressão à sexualidade, especialmente, a feminina; uma vez que o papel da mulher era o de cuidar da casa e dos filhos, apenas; ao homem era permitida a busca do prazer, inclusive fora de casa. A mulher, como em nosso estudo, assume o papel maternal e religioso, sublimando o desejo sexual e deslocando-o para outros tipos de desejos, conforme afirma Bernardi (1985).

Berger (2003) ainda lembra a relação sexual não consentida no casamento e refere que se assemelha à violência sexual quando as mulheres perdem o desejo sexual, pois tratase de uma condição banal no relacionamento conjugal, uma vez que tem respaldo social do sexo como dever conjugal.

Rebello (2006) comenta que ainda hoje os padrões dominantes de masculinidade exercem grande influência no comportamento sexual dos homens, podendo causar agravos à sua saúde. Contudo, a sexualidade humana é constituída através de padrões culturais que são determinados no decorrer da história, podendo modificar-se dentro de uma mesma sociedade, ao longo das gerações. 
Para Costa et al. (2001), as relações afetivas que pactuam respeito mútuo, normalmente desenvolvem-se sem discriminação de gênero e, nesta situação, nossos sujeitos reiteram o prazer de estarem com o parceiro, usufruindo de uma vida mais prazerosa, conforme relatam: “Cheio de fantasia né, a gente em quatro paredes ... eu e meu esposo ... a gente achando que é certo a gente fazia. Se for banheiro, chão, cama, onde fosse" (sujeito 36, fem.); "Era muito boa. Muito (melhor), muito carinho, era viver aquilo!" (sujeito 17, fem.); "Era bom! Amigo, carinhoso, delicado comigo. Sempre fomos felizes no casamento. Casei com ele arranjado pelo meu pai e deu muito certo!" (sujeito 35, fem.); "De primeiro eu queria direto, queria fazer sexo todo dia se fosse pra fazer" (sujeito 23, masc.).

Estudos mais recentes de Geluda et al. (2006) já acenam para uma situação de aparente eqüidade de poder entre os gêneros e salientam que vem ocorrendo mudança no campo de comportamento sexual, especialmente, entre os adolescentes aonde a mulher vem deixando de ser muda e submissa para se tornar um ser inteiro, atuante nos vários âmbitos da vida como no trabalho, amor e sexualidade, conforme ratifica Luz (1999).

Cardozo, Freitas e Fontoura (2002) reiteram que os jovens que recebem educação sexual mais adequada (sem tabus, falando sobre as dúvidas que têm) podem exercer atividades sexuais com segurança e prazer; cabendo à escola, um dos segmentos responsáveis pela educação do jovem, a necessidade de educá-lo e não apenas ensiná-lo.

\subsubsection{Conflitos}

Ao perguntar como estava a atividade sexual depois da ocorrência do problema no coração, na atualidade, grande parte dos sujeitos, independentemente do gênero, referiu dificuldades para manter esta ação sendo que houve aqueles que abandonaram, definitivamente, atividades que mantinham a genitalidade, há anos, enfatizando que, 
[...] Já não tinha vida ativa por causa do problema dele....tinha medo de infartar, faz muitos anos que a gente não ....uns quinze anos...ele veio cheio de doenças ....não conversávamos sobre isso, não! Simplesmente deixamos de fazer (sujeito 27, fem.).

Nesse momento tais sujeitos estavam acompanhados de seus (suas) parceiros (as) e apresentaram certa cumplicidade nas respostas, ao se olharem, durante os relatos; embora um sujeito tenha declarado que por ocasião da interrupção do exercício do coito não conversaram sobre o assunto. Houve também, na fala do sujeito, um momento de negação ao não assumir o término das relações sexuais quando assinalou, em princípio, que a mudança tinha sido praticamente total e, posteriormente, que havia acabado, de fato.

A sexualidade é um fator importante para a manutenção da qualidade de vida das pessoas e pode apresentar-se alterada em portadores de DAC (BEDELL; DUPERVAL; GOLDBERG, 2002). Ho e Fernandéz (2006) salientam que há estudos comprovando que problemas sexuais sempre acompanham quadros clínicos crônicos como no caso da HAS, DM e DAC; situações que merecem atenção especial dos profissionais de saúde para com o cliente/família, uma vez que necessitam de orientações específicas sobre seu problema de saúde e possíveis conseqüências, desta condição, para sua sexualidade.

O papel dos profissionais de saúde é fundamental, pois têm a responsabilidade de informar sobre a saúde/doença dos indivíduos incluindo tratamento e a orientação sobre a vida sexual (HO; FERNANDEZ, 2006).

Sabemos que a enfermagem ainda assume uma atitude conservadora diante da sexualidade do cliente e, desta forma, deixa de atendê-lo integralmente. O médico tende a tratar a sexualidade do paciente de modo geral e nos programas de reabilitação já se evidencia que apenas $25 \%$ dos sujeitos acometidos por infarto agudo do miocárdio e doenças cardíacas retornaram suas atividades sexuais normais (BEN-ZION; SHIBER, 2006). 
Estudos de Albanesi Filho (2000) acrescentam que o médico não discute sobre a prática sexual durante a consulta do portador de doenças cardíacas, pois se sente inseguro; devido à ausência de atualizações da literatura quanto ao tema e por não terem recebido aporte científico durante a formação; assim, ficam constrangidos para abordar sobre a vida sexual dos indivíduos e aguardam manifestação por parte do cliente/família.

Zilli (2000) refere que fatores de ordem pessoal, cultural e emocional estão presentes na relação do paciente com o médico e há relatos de que se sentem "embaraçados" quando têm de falar sobre o assunto.

Mesmo diante de iniciativas do sujeito 36, em nosso estudo, para esclarecer dúvidas acerca das dificuldades para atingir a ereção, houve emprego de linguagem figurada, por parte do(a) médico(a), para dizer ao sujeito que não deveria insistir nas tentativas; conforme relata:

[...] Falei com a minha médica, queria continuar a ser homem... mas ela disse que eu teria que parar de abanar café; que essa função era pesada para mim, agora! Que tinha passado da idade! Agora era para mim fazer coisinhas mais leves...e, aí, fiquei sem saber, mas parei! (sujeito 16, masc.).

O cônjuge/companheiro(a) normalmente compartilha do medo das complicações e ansiedade no retorno à atividade sexual do casal, após o aparecimento da doença aguda no(a) parceiro(a) e, nesse momento, cumplicidade e compreensão são sentimentos necessários a essa pessoa; além da disponibilidade e vontade de discutir o tema sexo e coração com o médico e o cônjuge, uma vez que poderá ter receio de praticar o ato sexual frente à possibilidade de alteração no quadro cardiológico (ALBANESI FILHO, 2000). Em nossa amostra o sujeito declara essa cooperação:

[..] Ah, ele é muito, assim...nessa parte ele me ajuda muito, ele é muito meu ajudador nessa parte. Ele me entende bem, não é um marido que fica cobrando, me entende. Até eu fiquei um tempo em repouso porque o doutor pediu, até saber dos exames, aí voltamos a uma vida sexual assim mais tranqüila, sem muita fantasia (sujeito 26, fem.). 
Investigações de Papadopoulos et al. (1986) destacam que o sexo feminino tem maior interesse em saber sobre as limitações que terão a partir da ocorrência da doença cardíaca e se manifestam, inclusive, com questões relativas à sua sexualidade nas consultas médicas. A iniciativa do profissional médico em abordar o assunto ainda é baixa, cerca de $18 \%$ do contexto de $45 \%$ do total destas iniciativas.

Embora, nos últimos anos, com o advento do desenvolvimento de drogas que tratam as alterações do desempenho sexual, a vida sexual das pessoas venha conquistando espaços na mídia e no cotidiano do médico, de acordo com Abreu (2000), muito ainda tem para se fazer e investigar, iniciando pelos estudos na área como um todo (hoje, as pesquisas ainda são pobres e as referências são escassas) até o desenvolvimento de uma auto-crítica do médico, dos enfermeiros e demais profissionais da saúde com relação à dificuldade para abordar a sexualidade do paciente frente à existência de patologias, bem como em seu aspecto preventivo. Tais condutas poderão impedir que os indivíduos deixem de viver suas vidas, de forma mais plena.

Pesquisas de Abreu (2000) salientam a evidente associação entre os fatores de risco para a cardiopatia e a disfunção sexual, porém aconselha ao médico a escuta das queixas dos clientes e a utilização de medicamentos que, atualmente, garantem o restabelecimento da vida sexual do indivíduo, sem riscos para a integridade cardiovascular.

Estatisticamente, sabemos que a atividade sexual pode provocar infarto agudo do miocárdio, mas há evidências que o risco absoluto é muito baixo, apresentando-se em duas chances por milhão, por um período de duas horas de atividade sexual (GAUI, 2000). Dados de Escosteguy (2000) demonstra que a freqüência de infarto do miocárdio, após o ato sexual, não é conhecida cientificamente; embora venha sendo relatada no cotidiano. 
Serra (2000) afirma que a freqüência de ocorrência de morte súbita durante a relação sexual é baixa, chegando a $0,6 \%$ dos casos; embora a freqüência cardíaca apresente diferença com maior elevação, quando as relações sexuais são extra-conjugais; de acordo com registros de freqüência cardíaca no sistema Holter. Este último achado também se evidenciou no estudo de Ueno (1963), quando estudou 34 casos de mortes súbitas ocorridas a partir da atividade sexual, sendo 27 (79\%) delas durante o coito extraconjugal. A situação pode ser explicada pela elevação significativa da freqüência cardíaca com um parceiro extraconjugal, levando ao aumento da demanda de oxigênio pelo miocárdio (UENO, 1963).

A atividade sexual com o(a) companheiro(a), segundo Albanesi Filho (2000), tem gasto calórico leve, com esforço cardíaco máximo não ultrapassando de 10 a 15 segundos e freqüência entre 90 a 144 batimentos por minuto (esforço compatível ao subir dois lances de escada ou ainda durante uma caminhada rápida.

Sabemos, também, que a prática de exercícios físicos, incluindo a atividade sexual, pode levar à ruptura de placas ateroscleróticas vulneráveis pelo aumento da atividade simpática durante o esforço, e conseqüente fibrilação ventricular na presença de condições favoráveis, segundo Maron (2000); porém Mittleman et al. (1993) assinalam que a atividade sexual representa cerca de $1,5 \%$ do total dos fatores desencadeantes do IAM.

Ressaltamos, contudo, que em estudos de Albert et al. (2000), ficou evidenciado o risco aumentado de morte súbita durante exercícios intensos e houve redução dos casos de mortes quando as atividades físicas foram regulares. Dados estes que possibilitam, de acordo com Serra (2000), Escosteguy (2000) e Lazzoli (2000), inferir que práticas regulares de atividade física, inclusive a sexual, podem ser fatores protetores contra risco de morte súbita. Baptista (2000) finaliza comentando que os benefícios da atividade física para 
portadores de DCV já foram demonstrados, mas apenas 10 a $15 \%$ dos portadores de IAM, nos EUA, participam de programas de reabilitação cardíaca.

Dentre as áreas para investigações, atualmente, já há uma gama de estudos, como do Instituto Nacional de Saúde dos Estados Unidos da América (1993), onde estima-se que 30 milhões de homens têm disfunção erétil - total ou parcial; sem dados precisos do mesmo acometimento no sexo feminino. No nordeste brasileiro, em um estudo de Moreira et al. (2000), com 602 indivíduos do sexo masculino, verificou-se que o quadro esteve presente em $40 \%$ da amostra.

A disfunção sexual é uma patologia que vem sendo amplamente discutida pela sociedade em face do aumento do número de ocorrência. Associada à pobre qualidade de vida (LAUMANN; PAIK; ROSEN, 1999) e a fatores de risco para cardiopatia, expressa um dos primeiros sinais da DCV, uma vez que os vasos penianos parecem ser mais susceptíveis à oclusão aterosclerótica que os demais (ANDERSON et al., 1998). Também são fatores desencadeantes para disfunção sexual, elevadas taxas de colesterol, o tabagismo e a idade; tendo prevalência três vezes maior em homens de 70 anos quando compara-se aos de 40 anos (FELDMAN et al., 1994; WEI et al., 1994; GAUI, 2000).

O medo de ter complicações cardíacas no ato sexual responde pela maioria das alterações da disfunção sexual que ocorre nos portadores de cardiopatias e se correlaciona com a doença instalada, pois estudo de Kollman (1984) refere que nos quadros de infarto do miocárdio, 10 a 15\% dos sujeitos evoluem com impotência e 40\% a 70\% apresentam prejuízos na freqüência e qualidade da atividade sexual; com diminuição da libido.

O esforço físico durante a atividade sexual e a emoção na hora do gozo são situações que amedrontam os portadores de cardiopatias e seus/suas companheiros(as); pois 
vêem nestas situações a possibilidade de morte pela sobrecarga de exercícios e sentimentos (CARVALHO; CIDADE, 2000).

Além do aspecto emocional, temos que considerar as terapias medicamentosas, uma vez que interferem na atividade sexual. Diuréticos como a hidroclorotiazida, estão associados a perdas da libido, disfunção erétil e diminuição da lubrificação vaginal; já betabloqueadores, como o propranolol, diminuem a libido e levam à disfunção erétil (PAPADOPOULOS, 1980).

Em nosso estudo, os sujeitos 23 (masc.) e 36 (fem.), referem que possuem vontade de estar com o(a) parceiro(a), mas têm dificuldades para a ereção:

[..] Ah filha, (a moda do outro, né) depois dos... já ta com uns 3 - 4 anos, né, pra cá... Não tinha problemas antes! É da parte da saúde, veio junto! Veio, veio, veio diminuindo. Depois que eu comecei tomar essa remedeira, ai que acabou mesmo, acabou! À moda do outro... aí desmontou mesmo! Não subia mais! (sujeito 23, masc.)

A esposa acrescentou "Ele tenta. Ele pensa, mas eu num gosto, fico brava porque eu num gosto. Dá canseira, muita canseira nele!” Ele acrescenta: “Dá pouco, muito pouco resultado! Tenho vontade. Sempre tive, né” (sujeito 30, masc.).

Estes dados corroboram aqueles descritos na literatura que registram a disfunção erétil como condição com alta prevalência na população e comprometimento significativo na qualidade de vida, do indivíduo e companheiro(a) (DOUMAS; DOUMA, 2006); especialmente em pessoas portadoras de hipertensão arterial; do sexo masculino. Pesquisas com mulheres hipertensas e a disfunção sexual ainda são incipientes (ZILLI, 2000).

A grande discussão é como tratar o cliente nesta condição uma vez que pouco se fala sobre o assunto (entre paciente e profissional de saúde); além da interação de drogas como Sildenafil com aquelas utilizadas na terapêutica de coronariopatias (os 
betabloqueadores, diuréticos e hipolipemiantes) (CHANG et al., 1991; SMITH; CATULO; DONHVE, 1995).

No caso da relação entre a ocorrência de disfunção erétil e hipertensão opta-se por diminuir a dose ou trocar a droga; sem prejuízo, obviamente, do efeito hipotensor (ZILLI, 2000). Alternativas como conversar com o cliente sobre a importância do uso contínuo do medicamento anti-hipertensivo e outras terapêuticas para disfunção erétil são necessárias, quando as possibilidades supracitadas não têm sucesso.

De acordo com o exposto anteriormente, estudiosos recomendam o trabalho em equipe como mecanismo no atendimento integral ao cliente. Desta forma, o cliente pode ter mais informações e estar mais esclarecido quanto ao seu problema cardíaco minimizando, com isso, temores ou receios com relação à atividade sexual; estado que pode levar ao aumento da auto-estima e à melhora da qualidade de vida.

Ainda existiram, em nosso estudo, sujeitos que estavam preocupados, principalmente, com a masculinidade e não dividiam as preocupações e tensões com o(a) parceiro(a): “Agora... bem agora, acontece também, mas tem o medo junto! Medo de ter a dor de novo! Medo de falhar! Sou homem" (sujeito 07, masc.).

[...] Agora é regrada, tenho medo de fazer feio. Ter a dor de novo, passar mal, não conseguir mais, sabe! Vem a vontade, mas também o medo! Não consigo falar para quem está comigo sobre meu medo! E se não vingar não tem como explicar! (sujeito 24, masc.)

A necessidade de desenvolvimento de relações igualitárias entre os sexos está discutida no estudo de Fonseca e Gomes (2004), tendo em vista a exigência de desconstrução para uma re-construção de gênero, no âmbito social, pois ainda tem maior valor à condição masculina. 


\subsubsection{Dificuldades de Relacionamento}

O relacionamento com o parceiro, em ambos os sexos, antes do problema no coração também foi comentado. Os sujeitos do estudo, embora enfatizassem o relacionamento como um todo, ainda trouxeram relatos sobre a vida sexual do casal, como: “Ah! Era sem vontade. Agora é com muito medo! Com desespero para acabar logo!" (sujeito 21, fem.) “Antes era bom!” (sujeito 10, masc.).

Este aspecto denota que estes sujeitos encaram o relacionamento, em grande parte, culminando na atividade sexual, confirmando a importância da genitalidade na relação.

Uma senhora refere-se às dificuldades que tinha com o companheiro ao assinalar: “Muita discussão, ciúme e desânimo" (sujeito 12, fem.).

Outros indivíduos revelam a cumplicidade, compreensão e amizade no relacionamento do casal, ao comentarem: "Ele me compreende muito, pra isso ele é muito parceiro mesmo" (sujeito 14, fem.); “Era normal, gostava de aproveitar só momentos bons!; "Era bom! Amigo, carinhoso, delicado comigo. Sempre fomos felizes no casamento. Casei com ele arranjado pelo meu pai e deu muito certo!" (sujeito 17, fem.); “Não! O relacionamento está a mesma coisa de hoje, graças a Deus, não mudou nada não. Normal" (sujeito 19, masc.) "Não, não mudou. Continua normal como era antes, como é agora" (sujeito 25, masc.) .

Estes dados são importantes para entendermos se houve mudança, com o aparecimento do problema de saúde; além de tentar levantar se os problemas de relacionamentos já eram anteriores ao problema de saúde. Conforme salientam Favarato et al. (2000) e Favarato (2004), a DAC leva a alterações emocionais que interferem na qualidade de vida dos indivíduos. Após terem sido acometidos pela patologia, têm comprometimento das áreas afetivo-emocional, intelectual e social e podem apresentar atitudes passivas, regressivas; ou ainda, atitudes de desconfiança, oposição e animosidade; ratificando atitudes dos sujeitos, em nosso estudo. 


\subsubsection{Preocupação}

Após verbalizarem como estava o relacionamento com o(a) parceiro(a), foram indagados quanto à relação com a família, na atualidade, e relataram preocupação dos membros familiares quanto à ocorrência da doença cardíaca; expressa nas falas de: "Do jeito que eles eram eles são, eles falam "também a senhora não pára", tem o mais novo que é muito preocupado comigo também, aí ele fala assim "larga as louça aí que eu lavo" (sujeito 25, masc.); “A menina casada, ela se preocupa comigo, pergunta de vez em quando ela pergunta e toca no assunto, né” (sujeito 08, fem.); 'E a dor como é que tá, já sarou, já passou ou ainda tá com ela?' E eu falo “De vez em quando ela aparece, né, Rosangela!’, ‘Ó mãe, precisa ir no médico, não fica assim não!' (sujeito 14, fem.); "Minhas filhas têm muito cuidado comigo, o menino homem também" (sujeito 28, fem.); "Minha mãe é muito preocupada comigo. Pergunta sempre se estou bem, precisando de alguma coisa. Acho que ficou assustada com o infarto meu! Os outros estão normais!” (sujeito 31, fem.).

Após os relatos dos sujeitos é possível inferir que há maior preocupação da família com a cliente portadora de coronariopatia, tornando-se evidente a assunção do cuidado (por parte dos filhos) com alguém que sempre cuidou deles.

O cuidado com o portador de cardiopatias, no caso de coronariopatia é discutido na literatura nacional, como no estudo de Carvalho e Cidade (2000), onde defendem uma relação médico-cliente efetiva/aberta, pois a cliente precisa de informações cruciais sobre seu problema de saúde que possibilitarão a continuidade de uma vida normal. Os clientes necessitarão saber sobre aspectos gerais de sua vida como alimentação, realização de exercícios, uso de drogas e suas implicações para a vida, entre outros.

Os autores supracitados ainda enfatizam a importância dos esclarecimentos visando manter e/ou estimular a auto-estima do cliente evitando, com isso, que se sinta inútil. Em 
nosso estudo, constatamos, no último trecho relatado, um sujeito que se sente incomodado com o cuidado excessivo da família:

[...] Sabe! Se preocupam muito. Inclusive meu filho mais velho fala: 'Mãe, mãe, tem que comer isso, mãe, a mãe (num) tá comendo verdura e fruta, hein, mãe!'. Falei, vixe filho, tô comendo sim! Pegar peso, eles não deixam eu pegar peso. Falam... 'deixa mãe, que eu pego'! Se preocupam muito. Começaram a pegar no meu pé, né! (sujeito 08, fem.)

A preocupação excessiva, muitas vezes, por zelo ou oportunismo, pode levar a família a tratar o cliente como incapaz, criando limitação em seu processo de viver (CARVALHO; CIDADE, 2000).

Outros sujeitos elaboram o cuidado dos familiares como algo positivo, que os coloca como pessoa importante/significativa no contexto familiar, que hoje, necessita de atenção especial, entendendo a doença cardíaca como qualquer outro processo patológico no ciclo de vida, como verbalizam: "Feliz. Meus filhos ama muito nóis, e eu amo muito ele" (sujeito 11, masc.);

[...] Ótima. Minha família é tudo pra mim, aqui vive a minha irmã, minha sobrinha de 5 anos e meu cunhado, de vez em quando ele bebe uns me aí, mas deixa pra lá. Mas minha filha ela é tudo pra mim, é o homem e a mulher da casa, trabalha em Ribeirão. Ela faz de tudo, nós num tem aquilo de falar você fez isso"; nós conversa assim igual...sabe... eu e ela. Ela tem um amor por mim, você precisa de ver, os outros ficam com inveja; tem meu irmão que mora aqui já faz uns 8 anos, mas ele vem fica em casa a cada 15 dias um mês porque ele é caminhoneiro (sujeito 14, fem.).

Em um relato, o sujeito 35 (fem.) afirma:

[...] Olha, a relação dos filhos, da minha mãe e da minha família, a gente sempre teve uma relação normal, sabe, se eu chegar e falar que não tô bem, todo mundo se preocupa porque não tô bem e vamos cuidar, vamos no médico, cuidar do que está acontecendo.

Os sujeitos 04 (fem.) e 07 (masc.) também exteriorizaram a solidão, a dificuldade de estarem sozinhos, naquele momento de vida, mas esclareceram estar num momento para se 
cuidarem mais, para se auto-cuidarem: "As meninas ficam tranqüilas em me deixar aqui sozinha, vou me cuidar!”; "Sou sozinho. Tenho que cuidar de mim. Do que sobrou! Da carcaça!”.

Nesse sentido, justifica-se a intervenção de enfermagem, segundo Foster e Benetti (2000), pois os indivíduos adultos têm dificuldade para manter a continuidade, qualidade e quantidade de auto-cuidado, necessárias à manutenção da vida e saúde. De acordo com George (1993), na teoria do auto-cuidado de Orem, levanta-se a possibilidade de "ações de saúde" serem atividades para prevenção de fatores de risco para patologias. Tais ações são orientadas pelo enfermeiro, para o cliente, que realiza a atividade, buscando a manutenção de sua vida, saúde e de bem-estar; assim, o atendimento de enfermagem promove o sistema de apoio-educação; com o cliente tendo uma ação orientada, que ele inicia e realiza, a fim de controlar os fatores de risco que afetam seu desenvolvimento.

Santos (1985) salienta que, na visão de Orem, o funcionamento do homem se dá em consonância com o seu ambiente e, juntos, formam um sistema; visto que o homem é "uma unidade funcionando biológica, simbológica e socialmente".

\subsubsection{Carências}

Após terem sido discutidas questões de vida, incluindo a sexualidade e a atividade sexual, foi deixado espaço para os sujeitos se manifestarem sobre o que quisessem, achassem importante ou ainda necessário. Muitos sujeitos exteriorizaram a preocupação de terem sido pertinentes nas respostas, e o sujeito 06 (fem.) verbalizou "acho que perguntou tudo que é certo, não sei se respondi certo". Acrescentamos para a pessoa que o objetivo da pesquisa não era avaliar se suas declarações estavam certas ou erradas, e sim tentar apreender necessidades, conflitos e inovações do portador de coronariopatias com relação aos enfrentamentos vitais a eles impostos, incluindo sua sexualidade e vida sexual, 
valorizando sua forma de resolução para essas questões e discutir, com eles, mecanismos de interferência diante desses obstáculos na busca de uma melhor qualidade de vida; considerando seu contexto existencial.

Outros sujeitos assinalaram carências, de ordem individual (que manifestam-se pelo desconhecimento da patologia que possuem e as implicações para suas vidas), e de caráter coletivo (quando vêem-se desprovidos de políticas públicas que respaldem e assegurem o acesso à saúde dos indivíduos, como agendamento para consultas, disponibilização de medicamentos e realização de exames), em ambos os sexos.

Ao demonstrar desconhecimento sobre seu quadro clínico, exteriorizou insegurança e dúvidas "Até que eu tenho saúde pra isso, agora tenho medo é disso aí, a idade chegar, perder a saúde e não ter como viver, né! É esse o negócio" (sujeito 36, fem.);

[...] Ah, eu penso assim, oh, eu gostaria de aproveitar que a gente está conversando, e aprofundar assim aos poucos, eu não sei até quando que eu vou continuar esse tratamento. Porque, o doutor Rodrigues pediu essa esteira, já tem o que, uns seis meses que to esperando marcar; (sujeito 23, masc.)

[...] Eu gostaria de falar. Para as pessoas, assim, se sentir algum sintoma mesmo que você fala assim ... ah, é um estresse. Veja porque eu vinha sentindo há tempo, entendeu? Mas, até eu não sei se vou entrar na relação de medicina, mas às vezes as pessoas um pouco com descaso, sabe? Às vezes você até reclama, mas aí ... ah, é o estresse, não faz um exame mais profundo, então aí você acaba achando também que é estresse e perde a vida por isso. Eu sempre tive essa dorzinha mas para mim mesmo era estresse, e eu mesmo falava para o médico que ... ah, é o estresse e isso passa, mas aí tenho, Graças a Deus, em primeiro lugar, e o Dr. Gustavo que ficou me pressionando, fez exames mais fundos aí deu que eu tinha esses problemas de válvula mitral, com essa angina daí então peço para as pessoas que quando achar que é estresse não pensar que é estresse, e procurar um cardiologista, procurar uma pessoa que entende para conversar, tirar idéia, pra se cuidar porque a vida vale a pena viver, né? A vida é bela, que apesar de tudo que esse mundo ta difícil, mas a gente precisa tornar para nós a vida bela para ser vivida. Deus deixou, a gente tem que agradecer a ele em primeiro lugar (sujeito 13, fem.).

Estudos de Silva (2003) acenam para esta realidade conflitante, pois portadores de AP instável tiveram dúvidas sobre como continuar a viver, a partir desse momento. Qual 
seria a nova forma de estar no mundo, portador de doença arterial coronariana? Assinalam que a falta de conhecimento ou conhecimento limitado sobre a patologia gera medo, angústia e depressão e determina a imobilização do ser humano no tocante a realização de atividades vitais, cotidianas; situação que poderá ser resolvida ou minimizada com diálogo, escuta e discussão sobre a doença e suas implicações para a vida diária; considerando o cliente e a família/responsável/companheiro(a).

Investigações de Murta et al. (1997) ratificam que pacientes cardíacos possuem conhecimentos precários e insuficientes sobre sua condição patológica e enfatizam a necessidade de medidas educativas, visando evitar/minimizar complicações.

Diante das declarações, é possível inferir que o papel de médicos e equipe de saúde está ocorrendo de forma limitada, não havendo um canal aberto, direto do cliente com a equipe multiprofissional.

Considerando esta lacuna, acrescenta-se à questão, o difícil acesso ao sistema público de saúde que nega a uma população a condição de cidadania, de direitos igualitários com assistência à sua saúde ao deixá-la insegura, sem respaldo, após anos a fio de cumprimento de deveres e a faz "pedir ajuda", a quem deveria apoiá-la, conforme verbalizam os sujeitos 06 (fem.) e 36 (fem.); respectivamente: "Acho que a gente precisa da ajuda das autoridades públicas dando apoio emocional, remédios, médicos, (quando é preciso) não a cada 06 meses! É uma segurança, sabe!”; “É muita coisa! Daria um livro! Não adianta! O governo não está interessado na gente!”

Esta conduta estimula a promoção da saúde e previne recidivas e reinternações. 
8 Desenvalvimento da eAcãa Educativa 
De acordo com a proposta do estudo, os sujeitos ainda durante a entrevista, foram convidados a participar de dinâmica de um grupo de discussões para trabalhar os assuntos identificados por eles mesmos como elementos problematizadores que ocorreriam, posteriormente, à coleta dos dados, com programação pré-estabelecida.

A grande maioria apresentou dúvidas sobre a sua condição de portador da coronariopatia, quais as causas da doença e diferenças entre sexo e sexualidade. Esta última questão acabou deixando os clientes inquietos quanto aos seus significados e manifestaram curiosidade para o entendimento sobre o assunto, logo após o término da gravação. Deixamos claro que retomaríamos as temáticas, mas que havia necessidade de pensarem sobre todos os aspectos levantados naquele momento, para que dividissem essa reflexão em nosso encontro, mais tarde.

Conforme achados dos resultados, em consonância com as hesitações evidenciadas nas falas dos sujeitos, foram selecionados os temas geradores, donde emergiram duas ações: a possibilidade de trabalhar/discutir com os sujeitos aspectos relativos aos fatores de risco para a DAC e implicações em sua sexualidade e a disponibilização da implementação da sessão de relaxamento para os sujeitos (sugestão deles mesmos), com posterior abertura para comentários sobre sentimentos acerca da experiência; além de uma confraternização, logo após a vivência, onde captaríamos sugestões e relatos sobre as atividades desenvolvidas, a partir das interações.

As primeiras vivências em grupo remontam da Grécia Antiga e, ao longo dos séculos, os grupos vêm ganhando espaço e força em face de seu papel no cenário social (MUNARI; FUREGATO, 2003). Enquanto recurso terapêutico, a psicoterapia de grupo foi desenvolvida por Joseph H. Pratt no Hospital Geral de Massachussets (Estados Unidos da 
América) e Bechelli e Santos (2004) comentam que Pratt, naquela época, orientava os clientes quanto à adoção de atitudes positivas frente às suas situações, aliadas aos cuidados clínicos; utilizando-se de aulas como método e da abordagem de reeducação e persuasão. Com a evolução dos tempos e conceitos, as características dos grupos foram mudando e os recursos metodológicos para realizar o trabalho com grupos também transformaram-se passando de aula para interação com associação da abordagem psicanalítica (BECHELLI; SANTOS, 2004), especialmente, na psicoterapia de grupo.

$\mathrm{Na}$ década de 30, surgiram trabalhos sobre grupos que se pautavam em princípios científicos e se apresentavam sistematizados permitindo, assim, que o trabalho com grupos pudesse ser explorado como campo de pesquisa e estudo; marcando a contribuição de Kurt Lewin, quando criou a expressão "dinâmica de grupo" (MUNARI et al., 2001).

De acordo com Munari, Cardoso e Medeiros (2001), a dinâmica de grupo refere-se aos movimentos do cenário de vida do sujeito e esta condição de estar em grupo é inerente a todo ser humano. O trabalho em grupo permite reflexões sobre o contexto vital das pessoas nele inseridas, podendo constituir-se em ambiente de acolhimento para discussões de suas questões; num movimento de interação entre os participantes e o coordenador do grupo.

Autores como Silva et al. (2003) ratificam que na dinâmica de grupo ocorre o movimento interno e externo do grupo, fazendo com que adquira características que são específicas; fundamentadas e geridas naquele grupo.

Costa e Munari (2004) enfatizam que na dinâmica de grupo ocorrem trocas de experiências entre os integrantes que, no caso de possuírem problemas semelhantes, começam a perceber que não são os únicos a enfrentar aquelas dificuldades e passam a dividi-las em busca de alternativas conjuntas para amenizá-las ou extingui-las. Assim, fica 
evidenciado o valor terapêutico do grupo; uma vez que, além da vivência de outros aspectos, ocorrem trocas de sentimentos comuns.

Os aspectos técnicos operacionais presentes no desenvolvimento de grupos que buscam a pesquisa devem ser considerados de forma criteriosa, uma vez que são itens necessários para alcançar o sucesso deste tipo de atividade e, por conseguinte, da investigação. Os autores pontuam, desta forma, o planejamento (atenção à adequação na coleta de dados com definição de papéis entre os envolvidos e domínio quanto à coordenação, observando/percebendo as forças existentes naquele grupo de trabalho), a organização (considerar a composição do grupo e seleção dos participantes, local, número de encontros e tempo de duração, além da coleta e registro dos dados); por fim, o desenvolvimento (cabe ao coordenador promover ambiente propício à apresentação dos membros do grupo, estimular a espontaneidade e conhecer os pressupostos que regem o trabalho em grupo) (MUNARI; CARDOSO; MEDEIROS, 2001).

Para planejamento e desenvolvimento das nossas atividades com o grupo, considerando a estrutura grupal (uma das variáveis utilizadas para a diferenciação do tipo de grupo), adotamos os fundamentos defendidos por Munari e Furegato (2003) e selecionamos o tipo de participante (foram convidados os sujeitos entrevistados em seus domicílios, portadores das coronariopatias); ressaltamos aspectos da prevenção primária pertinentes às doenças cardiovasculares associando os fatores de risco para as referidas patologias e a relação com a sexualidade destes indivíduos; além da atenção às variáveis físicas como seleção do dia para o encontro (os sujeitos foram consultados quanto a duas possíveis datas), qual o horário mais adequado para a maioria das pessoas e o período de duração do encontro. 
Em nossa vivência, os sujeitos foram convidados a realizar o encontro num espaço cedido pela Universidade de Ribeirão Preto, situado no Hospital Escola Centro Clínico Electro Bonini, onde foi possível preparar uma sala com clima agradável e tranqüilo, com cadeiras (para o primeiro momento, de discussões), colchonetes (para a implementação do relaxamento) e iluminação adequada para os dois momentos propostos, garantindo a privacidade e conforto dos sujeitos, conforme ressaltam Munari e Furegato (2003); além de recursos audiovisuais que permitiram mostrar fotos (figuras do sistema circulatório e do coração: visão externa e interna do órgão sadio e após infarto do miocárdio); fotos dos pulmões (órgão sadio e acometido por enfisema pulmonar); figuras esquematizadas do cérebro (anatomicamente sadio e com comprometimento pelo acidente vascular cerebral); esquemas dos vasos sanguíneos e o mecanismo de pressão que neles ocorrem, bem como a evolução da formação de ateroma no vaso sanguíneo, explicitando condições para ocorrência da dor anginosa e do infarto do miocárdio. Também foram mostradas fotos de pessoas com obesidade mórbida e dependentes do tabaco para discutirmos a partir das condições gerais dos clientes. Os materiais disponibilizados foram acessados no ambiente virtual, em sites onde é possível consulta pública. Este momento realizou-se em perfeitas condições e com sucesso, segundo as falas deles mesmos.

No momento da confraternização, os sujeitos foram encaminhados a um refeitório onde fizeram um lanche.

A prefeitura do município de Brodowski cedeu transporte para os participantes, tendo em vista a ausência de locais e recursos para a realização da intervenção naquela cidade e a disponibilidade das pessoas para se deslocarem até Ribeirão Preto.

Participaram das atividades educativas dezoito pessoas, num período de quatro horas; com presença de duas enfermeiras assistenciais daquele município. 
A ação educativa pautou-se em discussão e reflexão sobre definição de fatores de risco, sua classificação, implicação no processo saúde-doença e na vida dos sujeitos incluindo, também questões sobre a sua própria sexualidade.

Para início das atividades, os sujeitos foram recebidos e encaminhados à sala onde houve rápida apresentação de cada um por meio de uma estratégia grupal, buscando diminuir ansiedades e promover aproximação, conforme salientam Munari, Cardoso e Medeiros (2001); culminando em franca e livre discussão sobre os fatores de risco e suas implicações na sexualidade e, por conseguinte, na vida. Aqui, destacamos a importância de suas participações, uma vez que se tratava de um encontro dialógico, tornando-se possível, a interação do profissional e entre todos os sujeitos, exercitando o fato de aprender ensinando e de ensinar aprendendo ocorrendo esse processo mediatizador entre si, em cuja dinâmica era possível problematizar contextos sociais na tentativa de resgatar o exercício da cidadania e da dignidade, numa busca contínua de propostas e alternativas viáveis em seus cenários sociais.

Para Bueno, Ebissue e Cintrão (2007), o diálogo é a luz da relação humana, pois possibilita a crítica e a problematização da realidade, tendo em vista que os envolvidos nessa comunicação podem fazer perguntas e estimular o conteúdo dessa conversa a partir de elementos/valores de sua cultura e da consciência que possui delas.

Neste direcionamento, Feitosa (1999) assinala que Paulo Freire referia que seu pensamento pedagógico era muito mais um método de aprender do que de ensinar, pois numa relação de horizontalidade, educando e educador, são sujeitos na construção do conhecimento, contribuindo, individual e coletivamente, de forma crítica, com conteúdos que comporão a nova realidade ser experienciada, ou seja, vivida. 
Referindo então ao grupo em foco, além do convite à discussão dos termos, destacamos, portanto, a importância de ficarem à vontade, já que cada sujeito seria como se fosse uma semente, no sentido de discutir, rediscutir, sensibilizar e estimular a construção de conhecimentos sobre os fatores de risco para a DAC, tentando, nesse exercício de reflexão, trabalhar esses conceitos em sua própria realidade.

O início do diálogo se deu com a pergunta sobre o que eram fatores de risco para a doença no coração, qual o entendimento sobre essa questão. Os sujeitos participaram intensamente indicando os fatores de risco, após tê-los entendido como causas para a patologia cardíaca; exemplificando através de casos familiares do cotidiano, ou ainda, de notícias que havia ouvido na mídia. Comentaram (ainda que de forma desordenada), os fatores de risco modificáveis e não modificáveis, ilustrando que tiveram pressão alta desde muito jovens; que o diabetes era uma doença familiar que pais e irmãos possuíram e que também a havia adquirido, há anos. Pontuaram o sedentarismo, a alimentação inadequada (abuso de açúcar e gordura), o uso do álcool e do tabaco, a história familiar e a obesidade. Cada fator de risco foi retomado e discutido isoladamente, tendo sido classificado como modificável (passível de controle) e não-modificável (aqueles com características genéticas determinadas por genes familiares).

Durante o processo de interação dialógica, verificamos que os sujeitos tinham maior conhecimento sobre os fatores de risco modificáveis (HAS, DM, tabagismo, sedentarismo, obesidade, estresse e dislipidemia), embora com comentários superficiais; mas apresentando escassos conhecimentos sobre os fatores de risco não-modificáveis (sexo, idade, raça-etnia e ocorrência de menopausa), excetuando a história familiar (fator que foi indicado e comentado com grande ênfase). Mesmo não tendo sido indicados, os fatores de risco não pontuados foram retomados e trabalhados em sua classificação e significância. 
Alguns sujeitos referiram sobre a prática de exercícios físicos e salientamos a necessidade de avaliação clínica antes do início de atividades, pois que requeria esforço, demandando orientação segura e adequada. Houve sujeitos que mencionaram pedir sugestão de atividades para o seu médico visando acompanhamento, talvez iniciando com caminhadas. Quanto à atividade sexual reforçamos a importância de conquistarem e manterem a auto-estima elevada, com vistas à sua sexualidade e suas relações com os familiares e parceiros(as); estimulando-os a estabelecerem o diálogo franco e aberto, buscando novas descobertas, seja com o(a) companheiro(a), seu médico ou demais profissionais da saúde.

Foram também discutidas as definições de AP e IAM, demonstrando através de esquemas, as fases de formação da placa de ateroma e correspondência desses estágios com a sintomatologia das patologias referenciadas.

Ainda foram temas do encontro os efeitos (terapêuticos e colaterais) dos medicamentos utilizados para a hipertensão arterial, a interrupção do uso de drogas antihipertensivas e as complicações advindas deste ato; além de discutirmos os temas geradores de uma maneira geral, uma vez que permearam o diálogo e foram "nós" levantados na entrevista. Houve o relato de um dos participantes sobre o efeito benéfico da incorporação de hábitos saudáveis, como adoção de alimentação adequada e prática regular de exercícios físicos que fizeram-no perder peso, diminuir a dosagem do medicamento antihipertensivo e controlar os níveis glicêmicos na faixa de normalidades (entre 70 a 110 $\mathrm{mg} / \mathrm{dl})$, sem uso de hipoglicemiantes.

O estresse foi o último fator de risco comentado pelos sujeitos. Neste sentido, referimos tratar-se de um mecanismo de defesa do organismo humano contra eventos agressores; ou seja, uma resposta positiva e necessária, uma vez que traduz-se em reação 
diante da situação onde se apresentam perigos. Porém, se as agressões forem contínuas caracteriza-se como quadro patológico e, portanto, pode haver comprometimento da saúde das pessoas (AURIOL, 1985).

Assim, o estresse tem sido considerado como um problema de saúde pública, cada vez mais reconhecido em todo o mundo, acarretando depressão, irritabilidade e ansiedade; sendo importante, portanto, conceituá-lo como um processo e não como uma reação única, pois no momento em que a pessoa é sujeita a uma fonte de estresse, um longo processo bioquímico instala-se, cujo início manifesta-se de modo bastante semelhante; ocorrendo aparecimento de taquicardia, sudorese excessiva, tensão muscular, boca seca e a sensação de estar alerta. Isto posto, o estresse constitui-se de respostas biológicas compostas resultantes dos sistemas neurofisiológico, neuroendócrino e neuroimunológico, além de componentes comportamentais (BRASIO et al., 2003).

Então, o estresse deve ser conceituado como uma reação do organismo, a partir de alterações psicofisiológicas, que ocorrem quando uma pessoa se depara com uma situação que a irrita, amedronte, excite ou a confunda; circunstâncias que geram alterações no estado emocional, que causa a quebra do equilíbrio do organismo humano e exige adaptação (LIPP; MALAGRIS, 1995).

De acordo com Herman (1985), existe uma correlação entre a sociedade em que vivemos, altamente competitiva e premida pelo tempo, e a tensão mental influenciando na ocorrência de doenças cardíacas, por exemplo.

Para ajuste de reações corporais como a tensão muscular e as alterações de freqüências cardíaca e respiratória, podemos utilizar técnicas denominadas somáticas; incluindo técnicas de relaxamento, de respiração e de manejo da dor; com resultados 
eficazes, quanto ao relaxamento muscular que leva à diminuição dos níveis de ansiedade (LIPP, 1984).

Para Cungi (2004), relaxar é um fenômeno natural e indispensável aos seres humanos, pois existem diversos estudos demonstrando que o relaxamento favorece a concentração e otimiza o desempenho de qualquer atividade.

Auriol (1985) refere que o relaxamento é o que se opõe ao estresse, reforçando a homeostase e reduzindo, assim, a angústia e emotividade, a tensão muscular e a fadiga.

Miller (1987) obteve redução significativa nos parâmetros fisiológicos e na percepção de dor dos pacientes de seu estudo, ao utilizar o relaxamento com respiração profunda; atribuído ao estado de hipometabolismo, com diminuição da atividade simpática, registrando queda da pressão arterial, freqüências cardíaca e respiratória e menores níveis de tensão muscular.

Levando em consideração estes referenciais, trabalhamos com os sujeitos aqui pesquisados, implementando, nas nossas ações, sessão de relaxamento já que essa intervenção poderia diminuir a ansiedade, o tônus muscular e a fadiga; além de apresentarse como prática benéfica para a saúde, sem efeitos colaterais, não-invasiva e de baixo custo (PIMENTA, 1990). Após essa ação, recomendamos que assim o mantivessem fazendo no seu cotidiano, para melhorar a qualidade de vida deles.

A ansiedade e preocupação foram pontuadas como causas para o problema no coração pelos sujeitos e houve referência de $100 \%$ dos indivíduos do sexo masculino, quanto à presença constante do estresse em suas vidas. Desta forma, eles mesmos, confirmaram o interesse pela indicação de uma sessão de relaxamento dentre as atividades educativas propostas, logo após o momento da problematização; tendo sido esclarecido que essa técnica pode ser aprendida e usada em todos os aspectos da vida dos sujeitos, 
permitindo a otimização da vida humana, em tempos de contemporaneidade e de globalização.

Durante a sessão de relaxamento, os sujeitos permaneceram na sala, sentados, para o exercício respiratório. O ambiente estava com clima agradável, as luzes apagadas e com música suave para indução ao relaxamento. Após o exercício respiratório, foram conduzidos aos colchonetes, no mesmo espaço físico, onde deitaram-se para fazer o relaxamento corporal; com manutenção da música e olhos fechados, seguindo a voz de orientação quanto às ações que deveriam realizar. Foram utilizadas frases que se repetiam durante a "viagem imaginária" em busca do equilíbrio entre o corpo e a mente. Os sujeitos foram convidados a manterem uma atitude passiva, em posição confortável e, após cinqüenta minutos de atividade, foram retomando seu estado de alerta.

Os relatos sobre a experiência fluíram normalmente. Alguns referiram sensação de flutuação; outros falaram a respeito da condição de se sentirem naquele espaço, relaxados, com a sensação de sono, mas conscientes que deveriam viver aquele momento acordados; outros conseguiram dormir; e ainda apresentaram depoimentos de sensação de bem-estar, de estar se cuidando. Dois sujeitos relataram ter vontade de chorar e até mesmo sentiram lágrimas rolando pela face. Depois disso, sentiram um alívio enorme.

No geral, relataram sentimentos de leveza e de relaxamento após a sessão e acrescentaram a necessidade de viver essa experiência/sensação outras vezes, pois mesmo já tendo ouvido falar ou visto na televisão não conseguiam sentir o quanto é bom; nem imaginar o quanto o relaxamento faz bem para o corpo e para a mente.

Nestes relatos ficaram claras as presenças de fatores terapêuticos na vivência do grupo; pois conforme ressalta Yalom (1975, apud MUNARI; FUREGATO, 2003) estes fatores, também denominados curativos, são parâmetros norteadores, um elemento da 
terapia de grupo que contribui para que o grupo se torne terapêutico. Resumidamente, Guanaes e Japur (2001) e Munari e Furegato (2003) classificam os fatores terapêuticos em instilação de esperança, universalidade, oferecimento de informações, altruísmo, aprendizagem vicária, aceitação, orientação e catarse; fatores estes que tentaremos identificar nas falas e atitudes explicitadas pelos sujeitos no decorrer das atividades.

Alguns dos depoimentos dos sujeitos foram feitos durante a confraternização que ocorreu logo após o relaxamento, e outros enquanto aguardavam o transporte de volta para Brodowski. Naquele momento, três sujeitos (cada um por vez), comentaram que, após a atividade grupal e o relaxamento, até conseguiram entender e saber o que é sexualidade (aprendizagem vicária - reconhece que aprendeu a partir do outro membro do grupo), pois estavam se sentindo mais bonitos, mais cuidados e até mais atraentes (instilação de esperança - passando a acreditar que podem melhorar sua condição de saúde a partir do contato com o grupo); salientando que tentariam fazer o relaxamento com o companheiro.

Após a intervenção, antes que voltassem para seu município sugeriram outros encontros para novas discussões e exercícios, tanto em Brodowski como em Ribeirão Preto, enfatizando que sentiam necessidade de atividades como aquelas vividas, onde foi possível falar de coisas da vida em geral (auto-revelação - comentaram aspectos de suas vidas no grupo); além de aprender sobre suas doenças cardíacas e formas de enfrentá-la (universalidade e orientação - sentiram que não estavam sós e não eram os únicos a terem os problemas no coração, além de valorizarem as sugestões/orientações dos demais membros do grupo), sem receio de continuar vivendo normalmente. Aceitamos o desafio e pretendemos manter este trabalho com o referido grupo.

Este momento de término do grupo, no desenvolvimento da dinâmica grupal, compartilhando com Munari e Furegato (2003), foi vivido de forma individual e única por 
cada integrante do grupo que se apresentaram de diferentes formas: felizes, relaxados, pensativos, tranqüilos; tornando-se um momento que permitiu reflexões com relação ao trabalho e aspectos vivenciados durante toda atividade realizada.

Os relatos ratificaram a importância do papel do enfermeiro na orientação aos portadores de DAC, conforme salientam as autoras Suedekum, Cassol e de Martino (1995), pois os sujeitos mantiveram-se participantes e contribuíram para a construção da nova concepção de fatores de risco e das implicações para a sua vida e sua sexualidade.

Motta et al. (2007) ressaltam que o coordenador de grupo deve ter "clareza sobre o que é o processo, a dinâmica e o funcionamento grupal” e, para tanto, deve conhecer as bases científicas que envolvem sua prática, preocupando-se com os aspectos gerais que estão presentes no grupo que coordena, atentando-se aos valores, mitos, ritos e tabus existentes; além de definir os princípios e os pressupostos teóricos que adotará durante a atividade. Deve ter também "preparo e habilidades particulares" e deve estar presente desde a concepção até a avaliação da atividade grupal; condição que facilita identificar e reforçar aspectos terapêuticos presentes naquele grupo específico (SILVA et al., 2003).

Desta forma, conseguirá planejar e elaborar sua intervenção pautado em metodologias que facilitarão o processo e o desenvolvimento grupal, com o grupo constituindo-se em um espaço terapêutico onde os mediadores de mudanças (os fatores terapêuticos) possam atuar e ajudar o indivíduo em sua tomada de consciência como cidadão (GUANAES; JAPUR, 2001). Assim, o coordenador poderá ter um posicionamento mais adequado "assertivo" frente ao grupo e as questões que dele emergirem, tornando-se, de fato, o facilitador/estimulador no processo de mudança deste grupo.

Vale ressaltar também que o diálogo propicia ao indivíduo conhecer seu estado de saúde e entender, de forma mais organizada, seu quadro patológico; condição que 
possibilita conhecimento sobre comportamentos saudáveis e esclarecimentos sobre meios que minimizam complicações de seu estado geral. Nesse movimento de Educação para a Saúde, o indivíduo exercita seu direito de cidadania, podendo se articular com o sistema de saúde; conforme adverte Rocha (2007).

Por vez, no caso do relaxamento, a técnica a ser aplicada deve ser escolhida pelo enfermeiro, sendo necessários conhecimentos das técnicas e do cliente (sua disponibilidade, necessidades, preferências e condições de saúde). A incorporação deste tipo de assistência requer do enfermeiro uma visão de atendimento integral ao cliente (ALBUQUERQUE; CAVALCANTI, 1998); que deve ser entendido como um ser biopsicossociocultural, incluindo a sua dimensão sexual.

Assim, a Educação para a Saúde é considerada uma função do enfermeiro, que utiliza o trabalho em grupo como um dos mecanismos para estimular/potencializar o processo de mudanças nos indivíduos que participam das atividades grupais e, em qualquer momento, este profissional deve se apresentar pronto a motivar os clientes sobre a necessidade de aprender; tornando-se um facilitador, ou seja, um agente mediador neste processo ensino-aprendizagem. 
9 Conclusões e Considenaçôes PFinais 
Após a análise e discussão dos dados de identificação foi possível concluir que:

- A amostra constituiu-se de 36 sujeitos com idades entre 23 e 86 anos, de ambos os sexos; a maioria casada, com idades entre 41 a 50 anos e com ensino fundamental incompleto;

- A coronariopatia ocorreu nos indivíduos do sexo masculino, precocemente (a partir dos 23 anos) e aos 40 anos, no sexo feminino;

- Os indivíduos do sexo masculino manifestaram a doença mais cedo e apresentaram maior longevidade;

- Considerando o IMC, a maioria possui este índice acima de $25 \mathrm{~kg} / \mathrm{m}^{2}$;

- Sujeitos dos sexos masculino e feminino recebiam salários semelhantes, renda familiar entre 01 e 04 salários, com grande parte ganhando setecentos reais;

- Em relação ao sexo, a amostra difere quanto ao que consideram fator de risco para a ocorrência de sua doença no coração. A maioria das mulheres indicou a HAS e a história familiar, entre outros fatores. Porém, todos os homens apresentaram o estresse como fator de risco presente em suas vidas; seguindo em ordem crescente, a HAS, dieta inadequada, história familiar, além de outros fatores;

- Os homens referiram a ingestão excessiva de álcool, enquanto que as mulheres consideraram o risco pelo uso de estrógenos;

- A idade e a etnia não foram relacionadas como fatores de risco passíveis de causar a doença do coração dos sujeitos da amostra;

- Apenas as mulheres pesquisadas relacionaram o DM e a obesidade como fatores de risco para a ocorrência de suas doenças cardíacas; 
- Houve predomínio da AP como diagnóstico principal na amostra deste estudo; com o IAM se manifestando, em maior proporção em homens e a AP em mulheres;

- Neste estudo, foi possível extrair 11 temas geradores (saúde versus doença, medo da morte, fatores de risco, limitações, genitalidade, tabu, submissão, conflitos, dificuldades de relacionamento, preocupação e carências), considerando as questões pertinentes ao tema central, de acordo com os relatos dos sujeitos;

- O significado da vida para os sujeitos foi associado à existência de saúde na família como aspectos positivos e à ocorrência de sua doença, como algo negativo;

- Quanto à concepção saúde-doença, evidenciamos direcionamentos para uma visão fundamentada na teoria da determinação social onde saúde e doença compõem um amplo processo na vida deles; em movimento dinâmico de articulações de potenciais para viverem suas vidas; nos âmbitos socioeconômicos, políticos e culturais em seus cenários cotidianos;

- A maioria exteriorizou medo da morte, relacionando-a ao seu problema cardíaco revelando insegurança, ansiedade e impotência diante de sua patologia, destacando, portanto, o simbolismo do coração como um dos órgãos mais importantes do corpo humano. Todavia, alguns demonstraram conformismo e fuga a seu respeito;

- Em relação à causa da ocorrência de seu problema no coração muitos destacaram fatores de risco para a instalação da doença arterial coronariana, sendo os mais freqüentes: o estresse evidenciado (através de preocupação e ansiedade), a hipertensão arterial, o tabagismo e a obesidade;

- Com relação às dificuldades que encontraram frente à doença, pontuaram que esse quadro lhes impunha limitações sociais - devido às restrições financeiras para manutenção 
do tratamento cardiológico; físicas - relativas à dor torácica e cansaço; além das limitações emocionais, manifestadas pelo medo da morte e de complicações no quadro clínico;

- Os termos sexualidade e sexo foram considerados, pela maioria, como sinônimos; definindo-os como ato sexual, apresentando uma visão simplista do binômio, com expressão não verbal de vergonha e inibição; associando-os, apenas, à genitalidade. Porém, alguns ligaram-no à tradução de seus valores, culturas e formas de viver no mundo. Evidenciaram a existência do poder do gênero como produto social, apontando a submissão da mulher como mãe e dona de casa, bem como servil para o homem;

- A maioria relatou haver conflitos com relação à sua vida sexual após a ocorrência da patologia cardíaca, revelando dificuldades para manter a atividade sexual, além do abandono da(o) cônjuge. Alguns mantiveram-se silenciosos neste sentido. Ainda referiram que ao abrirem-se com seu médico, não houve acolhimento e nem orientação. Para alguns já existiam dificuldades de relacionamento com o(a) parceiro(a) antes da doença;

- Os sujeitos pesquisados relataram que há preocupação da família (filhos e pais) devido à enfermidade, entendendo que possa ser cuidado/carinho e, por outros, como ações que os incomodam, limitam-nos. Há citação, também, de solidão;

- No espaço aberto para falarem o que quisessem, desvelaram carências de âmbito individual (devido ao desconhecimento da patologia que os acometia) e de ordem coletiva (pela ausência de políticas públicas que garantissem o atendimento integral à saúde da população). Esta ausência de respaldos tem produzido cidadãos inseguros e repletos de dúvidas que se sentem angustiados, receosos e, às vezes, depressivos neste cenário que limita e imobiliza seres humanos em seu processo vital. 
Considerando a ação educativa, proposta através da metodologia da pesquisa-ação que problematiza a situação real, depreendemos ter havido participação efetiva dos sujeitos no sentido de discutirem seus contextos biopsicossociocultural e de saúde, procurando, de forma extremamente motivadora, entender as causas, os fatores de risco para a ocorrência e/ou complicações de seus quadros patológicos cardíacos, buscando a construção de uma nova realidade social onde prima-se pela melhoria da qualidade de vida; num movimento de cidadãos que refletem sobre o processo saúde-doença e solicitam articulação/respaldo no sistema público de saúde para atendimento de suas necessidades como seres humanos integrais.

Daí concluímos que a enfermagem, enquanto profissão que tem a responsabilidade de estimular o aprendizado, deve propor/implementar espaços dialógicos visando conhecer os clientes e assisti-los, orientando-os quando necessário, na evolução dessa reflexão e, nesse processo, podendo, assim, fazer a grande diferença no cuidado, utilizando-se de estratégias que reforcem hábitos e comportamentos saudáveis, que atendam os indivíduos em sua totalidade, atingindo aspectos íntimos e fundamentais como, por exemplo, as amplas questões que permeiam a sexualidade.

Depreendemos, então, que a população tem carência de profissionais de saúde envolvidos e preparados para o atendimento de suas necessidades individuais e coletivas; que, contudo, têm buscado seu espaço de atenção e requerido seus direitos como cidadãos.

Em suma, as doenças cardiovasculares, aqui representadas pela doença arterial coronariana, compõem o grupo de doenças crônico-degenerativas e devem ser prevenidas durante todo o processo vital. O olhar dos profissionais da saúde para esta questão deve sair da prática clínica convencional, indo além dos aspectos biopsíquicos; deve considerar os valores, a cultura, os hábitos, as formas de viver e enfrentar os problemas de cada cidadão; 
enfim, a forma com que cada ser humano consegue viver em seu contexto. A utilização da clínica ampliada permite a inclusão da lógica da determinação social no processo saúdedoença e possibilita vínculos e reflexões aos profissionais de saúde e clientes/usuários.

Neste sentido, salientamos a necessidade do reconhecimento da gravidade e complexidade da doença cardiovascular, também e especialmente, no sexo feminino; vislumbrando a criação e implantação de políticas de saúde que contemplem programas onde os direitos sejam igualitários entre os sexos. As ações devem possuir caráter global com relação aos comportamentos e hábitos relativos à saúde, pois assim, poderão auxiliar na melhoria da qualidade de vida das pessoas atendendo, inclusive, o exercício da sexualidade e atividade sexual, uma vez que sexo faz parte de uma vida normal e sexualidade é, acima de tudo, vida.

Os estudos, embora escassos, têm demonstrado que não há atenção suficiente dos profissionais de saúde com relação à saúde sexual do cliente/usuário, mantendo, ainda, atitude conservadora acerca dos aspectos referentes à sexualidade dos indivíduos.

A reabilitação dos portadores de coronariopatias prescinde conter, entre outros aspectos, a abordagem de sua dimensão sexual nos âmbitos da prevenção primária, secundária e terciária. Há necessidade de aumentar as pesquisas sobre a temática, bem como disponibilizar tratamentos para as disfunções sexuais que ocorrem em clientes cardiopatas.

Há que se considerar que trata-se de um desafio para os profissionais de saúde (médicos, enfermeiros, psicólogos, entre outros) nos desvencilharmos dos conceitos conservadores, limitados nos quais nos respaldávamos para lançarmo-nos no caminho da desconstrução de valores antigos e reconstrução de novos contextos de vida, onde profissionais da saúde e clientes, juntos, se situam num mundo de construção coletiva, num 
cenário com características sociopolíticoculturais diversas; onde podem e devem, igualmente, exercer sua cidadania em busca da melhoria da qualidade de vida tendo em vista a saúde para todos, como foco central das atuações. 
Referências Bibliográficas 
ABDO, C. H. N. Desenvolvimento sexual do Brasil: para curiosos e estudiosos. São Paulo: Summus, 2004.

ABREU, L. M. Impacto da terapia farmacológica na função sexual. Revista SOCERJ, v. 13, n. 5, P. 34-40, 2000.

ABREU, A. R; PEREIRA, M. C. R.; SOARES, M. T. P.; NOGUEIRA, N. Saúde. $1^{\text {a }}$ parte. Disponível em: http://www.mec.gov.br/sef/estrutz. Acessado em 25 de agosto de 2007.

ALBANESI FILHO, F. M. A doença cardíaca, a insegurança e a disfunção sexual. Revista SOCERJ, v. 13, n. 3, p. 50-56, jul./ago./set., 2000.

ALBERT, C. M.; MITTLEMAN, M. A.; CHAE, C. U.; LEE, I. M.; HENNEKENS, C. H.; MANSON, J. E. Triggering of sudden death from cardiac causes by vigorous exertion. The New England Journal of Medicine, v. 343, p. 1355-1361, 2000.

ALBUQUERQUE, M. C. S.; CAVALCANTI, M. S. L. Relaxamento: uma estratégia no contexto da assistência de enfermagem. Revista Brasileira de Enfermagem. Brasília, v. 51, n. 1, p. 35-58, 1998.

ALONSO, L. H. Sujeto y discurso: el lugar de la entrevista abierta en las prácticas de la sociologia cualitativa. In: DELGADO, J. M.; GUTIERREZ, J. (Org.). Métodos y técnicas cualitativas de investigación em ciências sociales. Madrid: Sínteses, 1995. cap. 8, p. 22539.

AMARO, S. Visita domiciliar: orientações para uma abordagem complexa. In: Desaulniers, J. (org.) Fenômeno, uma teia complexa de relações. Porto Alegre: EDIPUCRS, 2000.

ANDERSON, M.; NICHOLSON, B.; LOUIE, E.; MULHALL, J. P. An analysin of vasculogenic erectile disfunction as a potencial predition of occult cardiac disease. Journal of Urology, v. 159. supl. 5, p. 115, 1998.

ARMAGANIJAN, D.; BATLOUNI, M. Impacto dos fatores de risco tradicionais. Revista Sociedade de Cardiologia do Estado São Paulo, v.10, n. 6, p. 615-622, nov./dez. 2000.

ARTERIOCLEROSIS 1981. Report of the Working Group on Arteriosclerosis of The National Heart, Lung, and Blood Institute, v.1-2. Washington DC: US. Department of Health and Human Services, Public Health Services, NTH Public, 81-2034 and 82-2035, 1981-1982.

AURIOL, B. Introdução aos métodos de relaxamento. São Paulo, Manole, 1985. 134p.

AZEVEDO, A. C.; SOUZA, P. J. M.; BUENO, M. S. P.; LOYOLA, L. H. C.; ALBUQUERQUE, S. S. C.; SERKEFF, J. A. Isquemia silenciosa: seu aumento com a idade. Arquivos Brasileiros de Cardiologia, v. 57, n. 4, p. 281-285, out. 1991. 
BABERG, H. T.; JAGER, D.; KAHRMAN, G. Health promotion and cardiovascular risk factors. The level of knowledge among 510 impatients of an acute coronary care unit. Medizinische Klinik (Munich), v. 95, n. 2, p. 75-80, 2000.

BALlONE, G. J. Psicossomática e hipertensão arterial. Psiqweb. Disponível em: gballone.sites.uol.com.br/psicossomática/cardiologia. 2003. Acessado em 25 de agosto de 2003.

BANCO MUNDIAL. Brasil: novo desafio à saúde do adulto. Washington, 1991. 134p.

BAPTISTA, P. B. Epidemiologia de atividade física. Revista SOCERJ, v. 13, n. 4, out./nov./dez., 2000.

BECHELLI, L. P. C.; SANTOS, M. A. Psicoterapias de grupo: como surgiu e evoluiu. Revista Latino-Americana de Enfermagem, v. 12, n. 2, p. 242-249, mar./abr., 2004.

BEDELL, S. E.; DUPERVAL, M.; GOLDBERG, R. Cardiologists discussions about sexuality with patients with chronic coronary artery disease. American Heart Journal, v. 144, n. 2, p. 239-242, 2002.

BENNET, S. Cardiovascular risk factors in Australian: trends in socioeconomic inequalities. Journal of Epidemiolology Community of Health, v. 46, n. 4, p. 363 - 372, 1995.

BEN-ZION, I.; SHIBER, A. Health to hearth: rehabilitation of sexuality in cardiac patients. Harefuah, v. 145, n. 5, p. 350-351, 2006.

BERGER, S. M. D. Violência sexual contra mulheres: entrega a (in) visibilidade e a banalização. 184p.Dissertação (Mestrado) - Escola Nacional de Saúde Pública - Rio de Janeiro, 2003.

BERNARDI, M. A deseducação sexual. 2. ed. São Paulo: Summus, 1985.

BERTAZONE, E. C. O exercício da sexualidade de portadores de tuberculose pulmonar atendidos em Unidades Básicas de Saúde de Ribeirão Preto - SP. 102 p. Dissertação (Mestrado) apresentada à Escola de Enfermagem de Ribeirão Preto da Universidade de São Paulo, Ribeirão preto, 1998.

BESSER, H. W.; SILVA, N. A. S.; OLIVEIRA, G. M. A epidemiologia clínica das doenças cardiovasculares inacapacitantes do ponto de vista laborativo. Revista SOCERJ, v. 19, n. 4, p. 318-325, jul./ago., 2006.

BISON, R. A. P. Representações sociais dos estudantes de enfermagem sobre sexualidade numa experiência de ensino. 223p. Dissertação (Mestrado) Enfermagem Psiquiátrica e Ciências Humanas da Escola de Enfermagem de Ribeirão Preto da Universidade de São Paulo, Ribeirão Preto, 1998. 
BITTAR, O. J. N. V. Qualidade de vida após revascularização do miocárdio. Revista Brasileira de Cirurgia Cardiovascular, v. 7, n. 1, p. 1-8, jan-mar, 1992.

BODEN, W. E.; CAPONE, R. J. Coronary Care. Philadelphia, W. B. Saunders, 1984.

BOEMER, M. A. A morte e o morrer. São Paulo: Cortez, 1986.

BRANDÃO, A. P.; BRANDÃO, A. B.; MAGAlHÃeS, M. E. C.; POZZA, R. Epidemiologia da hipertensão arterial. Revista Sociedade de Cardiologia do Estado São Paulo, v. 13, n. 1, p. 7-19, jan./fev. 2003a.

BRANDÃO, A. A.; POZZAN, R.; MAGAlHÃES, M. E. C.; BRANDÃO, A. P. A importância do sexo masculino no determinismo de fatores de risco cardiovascular em adultos jovens acompanhados por 10 anos: estudo do Rio de Janeiro. Revista SOCERJ, v. 16, supl. A, p. 76, junho, 2003 b.

BRASIL. Ministério da Saúde; Secretaria de assistência à saúde. Departamentos de programas de saúde. Coordenação de doenças cardiovasculares. Controle de hipertensão arterial: uma proposta de integração ensino-serviço. Rio de Janeiro, 1993. 232 p.

BRASIO, K. M.; LALONI, D. T.; FERNANDES, Q. P.; BEZERRA, T. L. Comparação entre três técnicas de intervenção psicológica para tratamento da fibromialgia: treino de controle de stress, relaxamento progressivo e reestruturação cognitiva. Revista Ciências Médicas, Campinas, v. 12, n. 4, p. 307-318, out./dez. 2003.

BRAUNWALD, E. Tratado de medicina cardiovascular. 5. ed. São Paulo: Roca, 1999, v. 2, p. 1179-1460.

BRAUNWALD, E.; ANTMAN, E. M.; BEASLEY, J. W.; CALIFF, R. M.; CHEITLIN, M. D.; HOCHMAN, J. S. ACC/AHA Guidelines for Unstable Angina. Journal of the American College of Cardiology, v. 36, p. 970-1072, 2000.

BRAUNWALD, E. Examinations of the patient. In: Zipes, L. Heart disease a textbook of cardiovascular medicine. Saunders 5th ed, 2001. Chap 3, p. 35.

BRONSTEIN, M. Exercício e obesidade. Revista Sociedade de Cardiologia do Estado São Paulo, v. 6, n.1, p.111-116, jan./fev. 1996.

BRUNS, M. A. T.; ALMEIDA, M. G. O êxtase do temor vivido. Um estudo da sexualidade feminina na terceira idade. Revista Brasileira de Sexualidade Humana. São Paulo: Iglu, v. 5. n. 1, p. 64-81, 1994.

BUENO, S. M. V. Contribuição ao conceito de saúde-doença. 1991. Tese (Doutorado)Faculdade de Educação, Universidade de São Paulo, São Paulo.

Semântica do sinônimo de saúde/doença. 1993. 150 p. Tese (Doutorado)-Faculdade de Educação, Universidade de São Paulo, São Paulo. 
Marco conceitual e referencial teórico de educação para a saúde: orientação à prevenção de DST - Aids e drogas no Brasil para crianças, adolescentes e adultos jovens. Brasília, DF: Ministério da Saúde. 1997/8/mimeo.

Educação preventiva em sexualidade, DST - aids e drogas nas escolas-pesquisa-ação e o compromisso social. 263 p. Tese (Livre Docência)- Escola de Enfermagem de Ribeirão Preto da Universidade de São Paulo, Ribeirão Preto. 2001.

BUENO, S. M. V.; EBISSUE, C. T.; CINTRÃO, M. O diálogo no processo EnsinoAprendizagem. Temas em Educação e Saúde/ Centro de Pesquisas da Infância e da Adolescência "Dante Moreira Leite". Universidade Estadual Paulista - Faculdade de Ciências e Letras de Araraquara, v. 5, p. 107-131, 2007.

BUTLER, R. N.; LEWIS, M. J. Sexo e amor na terceira idade. 2. ed. São Paulo, Summus, 1985.

CABRAL, D. R. Metodologia da problematização aplicada em Unidades de Saúde 24 (vinte e quatro horas) $76 \mathrm{f}$. Monografia (Enfermagem) - Departamento de Enfermagem da Universidade Federal do Paraná, Universidade Federal do Paraná, Curitiba, 2002.

CAMMERER, M. A.; MANFROI, W. C.; MASCARENHAS, M. A. Homocisteína, doenças cardiovasculares e fatores nutricionais. Revista da Sociedade de Cardiologia do Estado de São Paulo, São Paulo, v. 11, n. 2, Supl. A, p. 10-17, março-abril. 2001.

CAMPOS, D. P. R. Aterosclerose: modernos conceitos. LAES/HAES, v. 9, n. 53, p. 22-26, jun.-jul. 1988.

CARDOSO, R. S.; SILVA, J. M. P.; FABRIS, V. E.; SILVA, M. A. M.; MARTINS, A. S.; SPADARO, J. Fatores de risco para o infarto agudo do miocárdio: estudo de 81 pacientes. Jornal Brasileiro de Medicina, v. 89, n. 1, 38-42, jul., 2005.

CARDOZO, D. M.; FREITAS, I. C.; FONTOURA, M. S. H. Comportamento sexual de adolescentes de gênero feminino de estratos sociais distintos em Salvador, Bahia, Brasil. Revista Paulista de Pediatria, v. 20, n. 3, p. 122-128, jun. 2002.

CARVAlHO, A. C. C.; SOUZA, J. M. Cardiopatia isquêmica. Revista Brasileira de Hipertensão, v. 8, n. 3, p. 297-305, julho-setembro. 2001.

CARVALHO, G.; MACHADO, M. N.; MAIA, L. M. Infarto agudo do miocárdio e morte súbita documentada. Arquivos Brasileiros de Cardiologia, v. 34, n. 1, jan. 2005.

CARVALHO, L.; CIDADE, W. Depressão, impotência e cardiopatia. Revista SOCERJ, v. 13, n. 3, p. 46-49, jul./ago./set., 2000.

CARVALHO, M. J. E.; TELLES, S. R. A. Considerações sobre queixas de pacientes em triagem de clínica-escola. Psikhe, São Paulo, v. 6, n. 1, p. 7-14, jan. 2001. 
CASSIDY, A. E.; BIELAK, L. F.; ZHOV, Y.; SHEEDY, P. F.; TURNER, S. T.; BREEN, J. F.; ARAOZ, P. A.; KULLO, I. J.; LIN, X.; PEYSER, P. A. Progression of subclinical coronary atherosclerosis: does obsety make a difference? Circulation, v. 111, n. 15, p. 1877 - 1882, apr., 2005.

CASTRO, M. E.; ROLIM, M. O.; MAURÍCIO, T. F. Prevenção da hipertensão e sua relação com o estilo de vida de trabalhadores. Acta Paulista de Enfermagem, v. 18, n. 2, p. 184-189, abr/jun., 2005.

CAVALCANTI, R.; CAVALCANTI, M. Tratamento clínico das inadequações sexuais. 2. ed. São Paulo: Roca, 1996, 480p.

CENTERS FOR DISEASE CONTROL AND PREVENTION, NATIONAL CENTER FOR HEALTH STATISTIC. Third National health and nutrition examination survey (NHANES III). Atlanta: National Heart, Lung and Blood Institute, 1991.

CESARINO, C. B.; CASAGRANDE, L. D. R. Paciente com insuficiência renal crônica em tratamento hemodialítico: atividade educativa do enfermeiro. Revista Latino-americana de Enfermagem, Ribeirão Preto, v. 6, n. 4, p. 31-40, out. 1998.

CHANG, S. W.; FINE, R.; SIEGEL, D.; CHESNEY, M.; BLACK, D.; HULLEY, S. B. The impact of diuretic therapy on refered sexual dysfunction. Archives of Internal Medicine, v. 151, p. 2402-2408, 1991.

CHIZZOTTI, A. Pesquisas em ciências humanas e sociais. São Paulo: Cortez, 1991.164p.

COELHO, O. R.; TOLEDO, J. F. B. A estratificação de risco nas síndromes coronarianas agudas, no primeiro atendimento. Revista Sociedade de Cardiologia do Estado São Paulo, v. 11, n. 4, jul./ago., 2001.

COELHO, O. R.; UETI, O. M. Angina estável: o que é consagrado e o que há de novo? In: TIMERMAN, A.; CESAR, L. A. M. Manual de Cardiologia do Estado de São Paulo/ SOCESP. São Paulo: Atheneu, 2000. Cap. 31, p. 141-146.

CORREIA, O. G. Dor: validação clínica no pós-operatório de cirurgia cardíaca. 1997. 128f. Dissertação (Mestrado em Enfermagem) - Escola de Enfermagem de São Paulo, Universidade de São Paulo, 1997.

COLOMBO, R. C. R. Estilo de vida e fatores de risco de pacientes com primeiro episódio de infarto agudo do miocárdio. Ribeirão Preto. 165 p. Dissertação (Mestrado) em Enfermagem. Escola de Enfermagem de Ribeirão Preto da Universidade de São Paulo, Ribeirão Preto, 1995.

COLOMBO, R. C. R.; AGUILlAR, O. M.; GALLANI, M. C. B. J.; GOBATTO, C. A.; Caracterização da obesidade em pacientes com infarto do miocárdio. Revista Latinoamericana de Enfermagem, Ribeirão Preto, v. 11, n. 4, p. 446-461, julho-agosto. 2003. 
CONN, V. S.; TAYLOR, S. G.; CASEY, B. Cardiac rehabilitation program participation an outcomes after myocardial infarction. Realibity Nursing, v. 17, n. 2, p. 58-61, 1992.

COSTA, K. S.; MUNARI, D. B. O grupo de controle de peso no processo de educação em saúde. Revista de Enfermagem da UERJ, v. 12, n. 1, p. 54-59, 2004.

COSTA, M. C. O.; LOPES, C. P. A.; SOUZA, R. P.; PATEL, B. N. Sexualidade na adolescência: desenvolvimento vivência e propostas de intervenção. Jornal de Pediatria. Rio de Janeiro, v. 77, supl. 2, 5217-224, nov., 2001.

COSTA, R. P. Os onze sexos: as múltiplas faces da sexualidade humana. São Paulo. Gente. 1994. 207p.

COSTA, R. V. C. Insuficiência cardíaca crônica e atividade física. Revista SOCERJ, v. 13 , n. 4, p. 34-36, 2000.

CUNGI, C. Saber relaxar na vida e no trabalho. São Paulo: Larousse do Brasil, 2004. $152 \mathrm{p}$.

CYRINO, E. G.; TORALLES-PEREIRA, M. L. Trabalhando com estratégias de ensinoaprendizagem por descoberta na área de saúde: a problematização e a aprendizagem baseada em problemas. Cadernos de Saúde Pública, Rio de Janeiro, v. 20, n. 3, p. 780788, mai-jun. 2004.

DANTAS, R. A. S. Perfil de pacientes com infarto agudo do miocárdio na perspectiva do modelo de "Campo de Saúde". 158 p. Dissertação (Mestrado)-Escola de Enfermagem de Ribeirão Preto/USP, Ribeirão Preto, 1996.

DEVON, H. A.; ZERWICK, J. J. The symptoms of unstable angina: do woman and men differ? Nursing Research., v. 52, n. 2, p. 108-118, Mar./ Apr. 2003.

DORÉA, E. L.; LOTUFO, P. A. Framingham heart study e a teoria do contínuo: duas contribuições da epidemiologia para a associação entre pressão arterial e doença cardiovascular. Revista Brasileira de Hipertensão, v. 8, n. 2, p. 195-200, 2001.

DOUMAS, M.; DOUMAS, S. The effect of antihypertensive drugs on eretile function: aproposed managemeint algorithm. Journal Clinical Hipertension (Junwich), v. 8, p. 359364, 2006.

DUARTE, P. S.; MASTROCOLlA, L. E.; ALONSO, G.; LIMA, E. V.; SMANIO, P. E.; OLIVEIRA; M. A.; MARTINS; L. R.; PEREIRA, J. C. Associação entre fatores de risco para a doença arterial coronariana e coronariopatia em pacientes submetidos à angiografia de perfusão do miocárdio. Arquivos Brasileiros de Cardiologia, v. 88, n. 3, mar., 2007.

ENGEL, G. L. Sudden and rapid death during psychological stress. Annals of Internal Medicine., v. 74, p. 771-782, 1971. 
ESCOBIllanA, P. C.; RETAMAL M. J.; CANIGUANTE, B. G.; ARÉVAlO, V. M.; SANHUEZA, C. P. Epidemiologia del infarto agudo al miocárdio em el hospital San Juan de Dios em el período 2004-2006. Bulletin Hospital San Juan de Dios, n. 53, n. 5, p. 250253, sept./oct., 2006.

ESCOSTEGUY, C. C. Atividade sexual e risco cardíaco: associação real ou coincidência? Revista SOCERJ, v. 13, n. 3, p. 16-22, jul./ago./set., 2000.

EVANS, T.; WHITEHEAD, M.; DIDERICHS, F.; BHUIYA, A.; WIRTH, M. ed(s). Chalenging inequities in health: from ethics to action. New York: Oxford University Press, 2001.

ÉVORA, P. R. B.; ROSELINO, C. H. C. D. Noções gerais de cirurgia cardíaca. Divisão de cirurgia, ortopedia e traumatologia da Faculdade de Medicina da Universidade de Ribeirão Preto-UNAERP-2002.

FARMER, J. A.; GOTTO JR., A. M. Dislipidemia e outros fatores de risco da doença arterial coronária. In: BRAUNWALD, E. Tratado de Medicina Cardiovascular. São Paulo: ROCA, 5. ed., 1999. p. 1202-1235.

FARRIS, R. P.; HANEY, D. M.; DUNET, D. O. Expanding the evidence for health promition: developing best practices for WISEWOMAN. Journal Womens Health (Larchmt), v. 13, n. 5, p. 634-643, 2004.

FAVARATO, M. E. C. S.; ALDRIGHI, J. M.; FRÁGUAS JR, R.; PIRES, A. L. R.; LIMA, S. M. R. R. Sexualidade e climatério: influências de fatores biológicos, psicológicos e sócio-culturais. Reprodução e Climatério, São Paulo, v. 15, n. 4, p. 199-202, 2000.

FAVARATO, M. E. C. S.; ALDRIGHI, J. M. A mulher coronariopata no climatério após a menopausa: implicações na qualidade de vida. Revista Associação Médica Brasileira; v. 47, n.4, p. 339-45, 2001.

FAVARATO, M. E. C. S. Qualidade de vida em portadores de doença arterial coronariana submetidos a diferentes tratamentos: comparação entre gêneros. 87 p. Tese (Doutorado) - Departamento de Saúde Materno Infantil da Faculdade de Saúde Pública da Universidade de São Paulo. São Paulo, 2004.

FEITOSA, S. C. S. O Método Paulo Freire. Disponível em: http:// www.paulofreire.org/bibliotece/método. Acessado em 22 de agosto de 2007.

FELDMAN, H. A.; GOLDSTEIN, I.; HATZICHRISTOU, D. G.; KRANE, R. J.; MCKINLAY, J. B. Impotence and its predical and psychosocial correlates. Results of Mossachussets Male Aging Study. Journal of Urology. V. 151, p. 54-61, 1994.

FERRÃO, C. Aspectos psíquicos do paciente com câncer. Disponível em: http://www.netpsi.com.br/artigos. Acessado em 26 de agosto de 2007. 
FERREIRA, B. A. Considerações sobre fatores de risco para a doença arterial coronariana. Revista Nursing, p. 30-34, maio. 2000.

FERREIRA, M. A.; FIGUEIREDO, N. M. A. Expressão da sexualidade do cliente hospitalizado e estratégias para o cuidado de enfermagem. Revista Brasileira de Enfermagem, Brasília, v. 50, n. 1, p. 17-30, jan./mar. 1997.

FERNANDES, I. C.; SÁ, S. V.; SILVA, A. M. S. P.; CURI, A. N.; FREIRE, C. R. S.; ALMEIDA, M. L.; PERS, M. C. M.; DINIZ, S. M. F.; ALENCAR, V. M. R.; BORGES, Z. M. Diabetes mellitus e dislipidemia. Jornal de Medicina, v. 79, n. 3, p. 39-44, set. 2000.

FONSECA, A. D., GOMES, V. L. O. Manifestações de gênero no processo de adolescer. Acta sci, Health sci, v. 26, n. 1, p. 231-237, jan.-jun., 2004.

FONSECA, M. G.; TRAVASSOS, C.; BASTOS, F. I.; SILVA, N. V.; SZWARCWALD, C. L. Distribuição social da aids no Brasil segundo participação no mercado de trabalho, ocupação e status sócio-econômico dos casos de 1997 a 1998. Cadernos de Saúde Pública, v. 19, n. 5, p. 1351 - 1363, set./out., 2003.

FORTI, N.; GIANNINI, S. D.; DIAMENT, J.; ISSA, J.; FUKUSHIMA, J.; DALBÓ, C.; BARRETO, A. C. P. Fatores de risco para doença arterial coronariana em criança e adolescentes filhos de coronariopatas jovens. Arquivos Brasileiros de Cardiologia, v. 66, n. 3, p. 119-123, 1996.

FOSTER, P. C.; BEnNetTi, A. M. Dorothea E. Orem. In: GEORGE, J. B. Teorias de enfermagem: fundamentos à prática profissional. 4. ed. Porto Alegre: Artmed, 2000.

FOUCAULT, M. História da sexualidade I: a vontade de saber. 11. ed. Rio de Janeiro, Graal, 1988.

FRACOLLI, L. A.; BERTOLOZZI, M. R. A abordagem do processo saúde-doença das famílias e do coletivo. Manual de Enfermagem. 2001. Disponível em: http: www.idssaúde.org.br/enfermagem. Acesso em 25 de agosto de 2007.

FRASURE-SMITH, N.; LESPÉRANCE, F.; TALAJIC, M. Depression and 18-month prognosis after myocardial infarction. Circulation, v. 91, n. 4, p. 999-1005, 1995.

FREIRE, P. Criando métodos de pesquisa alternativa: aprendendo a fazê-la melhor através da ação. In: BRANDÃO, C. R. Pesquisa participante. São Paulo: Brasiliense, 1990. p.3437.

FREUD, S. Três ensaios sobre a sexualidade. In: FREUD, S. Obras psicológicas completas de Sigmund Freud. 2. ed. Rio de Janeiro, Imago, 1987, v. VII, p. 119 - 126.

GARCIA, T. R. Sexualidade Humana: Conhecimento necessário à formação do Enfermeiro. Acta Paulista de Enfermagem, São Paulo, v. 6, n. 1/4, p. 39-42, jan. 1993. 
GAUI, E. N. Atividade sexual em portadores de angina estável. Revista SOCERJ, v. XIII, n. 3, jul./ago./set., 2000.

GELUDA, K.; BOSI, M. L. M.; CUNHA, A. J. L. A.; TRAJMAN, A. Quando um não quer, dois não brigam: um estudo sobre o não uso constante de preservativo masculino por adolescentes do município do Rio de Janeiro. Cadernos de Saúde Pública, v. 22, n. 8, p. 1671-1680, ago., 2006.

GEORGE, J. B. Teorias de enfermagem: os fundamentos para a prática profissional. Porto Alegre: Artmed, 1993.

GEOVANINI, T.; MOREIRA, A.; SCHOELLER, S. D.; MACHADO, W. C. A. História da Enfermagem: Versões e interpretações. Rio de Janeiro. Revinter, 1995.

GIANNINI, S. D.; FORTI, N.; DIAMENT, J. Fatores de risco e estratégias preventivas: intervenções populacionais. In: Cardiologia preventiva: prevenção primária e secundária. São Paulo: Atheneu, 2000. p. 43-49.

GIGANTE, D. P.; DIAS-DA-COSTA, J. S.; OLINTO, M. T. A.; MENEZES, A. M. P.; MACEDO, S. Obesidade na população adulta de Pelotas. Rio Grande do Sul, Brasil e associação com nível sócio-econômico. Cadernos Saúde Pública, v. 22, n. 9, p. 18731879, set., 2006.

GIORDANI, A. T. Pesquisa-ação com mulheres detentas sobre sexualidade, DST - aids e drogas. 163 p. Dissertação (Mestrado)-Escola de Enfermagem de Ribeirão Preto da Universidade de São Paulo, Ribeirão Preto, 2000.

GIORDANI, A. T. Violência sexual e vulnerabilidade às IST - aids em mulheres detentas. 551 p. Tese (Doutorado) -Escola de Enfermagem de Ribeirão Preto da Universidade de São Paulo, Ribeirão Preto, Ribeirão preto, 2003.

GIR, E. A sexualidade e a mulher portadora do vírus da imunodeficiência humana tipo 1 (HIV-1). 201 p. Tese (Livre Docência) - Escola de Enfermagem de Ribeirão Preto, da Universidade de São Paulo, Ribeirão Preto, 1997.

GREENLAND, P.; REICHER-REISS, H.; GOUDBOURT, U.; BECHAR, S. Isracieli sprint investigators: in - hospital and 1 year mortality in 1524 women after myocardical infarction. Circulation, v. 83, p. $484-491,1991$.

GUANAES, C.; JAPUR, M. Fatores terapêuticos em um grupo de apoio para pacientes psiquiátricos ambulatoriais. Revista Brasileira de Psiquiatria, v. 23, n. 3, p. 134-140, 2001.

GUIMARÃES, A. C. Atualização na prevenção de doenças cardiovasculares. Revista da Sociedade Brasileira de Hipertensão, v. 2, n. 6, p. 61-65. 2003. 
GUS, I.; FISHMAN, A.; MEDINA, C. Prevalência dos fatores de risco da doença arterial coronariana no estado do Rio Grande do Sul. Arquivos Brasileiros de Cardiologia, v. 78, n. 5 , p. $478-483,2002$.

HAGUETTE, T. M. F. A observação participante. In: HAGUETTE, T. M. F. Metodologias qualitativas na sociologia, 5. ed. Petrópolis: Vozes, 1997, cap. 6, p. 66-78.

HAJE, L. A história da sexualidade. 2005. Disponível em swplace.home/cultura/sexualidade. Acessado em 11 de julho 2006.

HATCHETT, T. R. Coronary heart disease: the management of unstable angina, myocardial infarction, and current challenges. PDNT, v. 97, n. 46, p. 43 - 46, nov., 2001.

HELMAN, C. G. Cultura, saúde e doença. 2. ed. Porto Alegre, Artes Médicas, 1994.

HERMAN, J. A. The concept of relaxation. Journal of Holistic Nursing, v. 3, n. 1, p. 15$18,1985$.

HIGUCHI, M. L.; GUTIERREZ, P. S. Avanços na patologia da placa arterosclerótica. Revista Sociedade de Cardiologia do Estado de São Paulo, v. 12, n. 4, p. 694-704, 2002.

HO, T. M.; FERNÁNDEZ, M. Patient's sexual health: do we care enough? EDTNA GRCA Journal, v. 32, n. 4, p. 183-186, oct-dec, 2006.

HOCHMAN, J. S.; TAMIS, J. E.; THOMPSON, T. D.; WEAVER, W. D.; WHITE, M. B.; VAN de WERF, F. Sex, clinical presentation, and outcome in patients with acute coronary syndromes. Global use of strategies to open occluded coronary arteries in acute coronary syndromes investigations. The New England Journal of Medicine, v. 341, n. 4, p. $226-$ 232, 1999.

HOGAN, R. M. Human Sexuality: a nursing perspective United States of América: Appliton-Century Crofts, 1985.747 p.

HONS, D. Doença grave e fim da vida - reflexão sobre o sofrimento e seu acompanhamento. Neuvelle Revue Théologie, n. 119, p. 252-255, 1997.

HURST, J. W. O coração. 6. ed. Rio de Janeiro: Guanabara Koogan, 1990. v. 1, p. 588750.

INSTITUTO BRASILEIRO DE GRÁFICOS E ESTATÍSTICA - IBGE. Resultados da Amostra do Censo demográfico 2000 - Malha municipal digital do Brasil: situação em 2001. Rio de Janeiro: IBGE, 2004.

INSTITUTO NACIONAL DO CÂNCER - INCA. Estimativas de incidência e mortalidade por câncer. Rio de janeiro: INCA, 2002. Disponível em: http://w.w.w.inca.gov.br/tabagismo. Acesso em 25 de junho de 2006. 
INTERNATIONAL LIPID INFORMATION BUREAU (ILIB) LATINO AMERICA. Recomendaciones de ILIB para el diagnóstico de las dilipidemias en Latino America. Cardiovascular Risk Factors, v. 3, n. 1, p.10-27, Suplemento 1, 1994.

INTROCASO, L. História natural de aterosclerose. Revista Atheriosclerosis, v. 12, n. 1, p. 27-32, 2001.

JARAMILLO VÉLEZ, D. J., URIBE JA RAMILLO, T. M. Hacia uma nueva cultura de la sexualidade y la convivência em jovens escolarizados. Investigación y Educación en Enfermería., v. 14, n. 2, p. 37-53, sept., 1996.

KALACHE, A. Envelhecimento no contexto internacional. A perspectiva da Organização Mundial de Saúde. In: SEMINÁRIO INTERNACIONAL-ENVELHECIMENTO POPULACIONAL: UMA AGENDA PARA O FINAL DO SÉCULO, 1, 1996. Brasília. Anais Brasília: Ministério da Previdência e Assistência Social, 1996.

KAMARCK, T.; JENNINGS, J. R. Behavioral factors in sudden death. Psychology Bulletin, v. 109, p. 42-75, 1991.

KANNEL, W. B.; DAWBER, T. R. Atherosclerosis as a pediatric problem. Journal of Pediatrics., v. 80, p. 544-554, 1972.

KANNEL, W. B. Natural history of cardiovascular risk. In: HOLLENBERG, N. K. (ed.). Hypertension: mechanisms and therapy: Ed Current Medicine, 1995. Cap. 5, p. 2-22.

KANNELL, W. B. Harzards, risk and threats of heart disease from the early stages to symptomatic coronary heart disease and cardiac failure. Cardiovascular Drugs Theraphy, v. 11, Suppl. 1, p. 199 -212, 1997.

KAPLAN, H. S. O desejo sexual - e novos conceitos e técnicas da terapia do sexo. Rio de Janeiro: Nova Fronteira, 1983. 231p.

KLEIN, C. H.; ARAUJO, J. W. G. Fumo, bebida alcoólica, migração, instrução, ocupação, agregação familiar e pressão arterial em Volta Redonda. Caderno de Saúde Pública, v. 1, p. 160-176, 1985.

KLEIN, C. H.; SOUZA E SILVA, N. A.; NOGUEIRA, A. R.; BLOCH, K. V.; CAMPOS, L. H. S. Arterial hypertension in Ilha do Governador, Rio de Janeiro Brazil: II prevalence. Cadernos de Saúde Pública, v. 11, n.3, p. 389-394, 1995.

KOCH, F.; SALERMO de MINA, M. R. Los factores de riesgo coronário en la población adulta sana de San Miguel de Tucumán. Ciências Médicas., v. 7, n. 4, p. 223-234, jul./ago. 1992.

KOLLMAN, P. B. R. Sexual dysfunction and postmyocardial infarction patient. Journal of Cardiac Rehabilitation., v. 43, p. 334-340, 1984. 
KOLODNY, R. C.; MASTERS, W. H.; JOHNSON, V. E. Manual de Medicina Sexual, p. 235-273, 1982. Suplemento 1.

KOVÁCS, M. J. Morte e desenvolvimento humano. São Paulo: Casa o Psicólogo, 1992.

KUCZMARSKI, R. J.; FLEGAL, K. M.; CAMPBELL, S. M.; JOHNSON, C. L. Increasing prevalence of overweight among US adults: the National Health and Nutrition Examination Surveys, 1960 a 1991. JAMA, v. 272, n. 205, 1994.

KUNIK, H. Objetivos y fases de la rehabilitación cardíaca. Revista Argentina de Medicina del Deporte, v. 16, n. 53, p.65-72,1994.

KUSNETZOFF, J. C. O homem sexualmente feliz: do mito à verdade científica. 5. ed. Trad. de Anilde Werneck. Rio de Janeiro. Nova Fronteira, 1987. 263 p.

LAMOSA, B. W. R. As peculiaridades da atenção psicológica dispensada em unidades hospitalares de cardiologia. In: LAMOSA, B. W. R. (Org.). Psicologia aplicada à cardiologia. São Paulo: Fundo Editorial Byk, 36-44. 1990.

LAUMANN, E. O.; PAIK, A.; ROVEN, R. C. Sexual dysfunction in the United States: prevalence and predictions. JAMA, v. 281, p. 537-544, 1999.

LAURELL, A. O. La salud-enfermedad como proceso social. Revista Latino-americana de Salud, México, v. 2, p. 7-25, 1982.

LAZOLLI, J. K. Doença arterial coronariana e atividade física. Revista SOCERJ, v. 13, n. 4, out./nov./dez., 2000.

LEGATO, M. J. Women's health: not for women only. International Journal of Fertility Womens Medicine, v. 43, n. 2, p. 65 - 72, 1998.

LESSA, I. O adulto brasileiro e as doenças da modernidade: epidemiologia das doenças crônicas não transmissíveis. São Paulo: Hucitec, 1998.

LESSA, I. Prevalência de hipertensão no Brasil. Revista Brasileira de Hipertensão, v. 6, n.3, p. 319-321, 1999.

LERARIO, A. C.; LOTTENBERG, S. A. Mecanismos ambientais implicados no ganho de peso e as oportunidades para prevenção da obesidade. Einstein (São Paulo); n. 4(supl.1), p. S7-S13, 2006.

LIBERMAN, A. Síndromes coronárias agudas no idoso: qual a diferença? Revista Sociedade de Cardiologia do Estado de São Paulo, São Paulo, v. 12, n. 4, p. 497-507, julho-agosto. 2002.

LIBERMAN, A. Aspectos epidemiológicos e o impacto clínico da hipertensão no indivíduo idoso. Revista Brasileira de Hipertensão, v. 14, n. 1, p. 17 - 20, jan./mar., 2007. 
LIPP, M. E. N. Stress e suas implicações. Estudos de Psicologia, v. 1, n. 3/4, p. 5-19, 1984.

LIPP, M. E. N.; MALAGRIS, L. E. N. O manejo do stress. In: RANGE, B. (org). Psicoterapia comportamental e cognitiva. Campinas: Ed. Psy, v. 24, p. 179-292, 1995.

LOLIO, C. A. Epidemiologia da hipertensão arterial. Revista Saúde Pública, v. 24, p. 425432, 1990.

LOPES, G.; TORRES, L. O.; MONTGOMERY, M.; MARQUES, C. M.; CARVALHO, M. A. M.; NASCIMENTO, L. G.; MAIA, M. B. Patologia e terapia sexual. Rio de Janeiro, Ed. Médicas e Científicas, 1994, p. 3-12.

LOTUFO, P. A. Epidemiologia das doenças cardíacas no Brasil: histórico, situação e proposta de modelo teórico. Revista Sociedade de Cardiologia do Estado São Paulo, v. 6, n. 5, p. 541-547, set./out. 1996.

LOUREIRO, M.; VAZ, M. R. C. Refletindo sobre o ensinar e aprender para a antinomia e a transformação da realidade. Texto Contexto Enfermagem, Florianópolis, v. 9, n. 3, p. 230-248, ago-dez 2000.

LOURES, D. L.; SANTANNA, I.; BALDOTTO, E. S. R.; SOUSA; E. B.; NÓBREGA, A. C. L. Estresse mental e sistema cardiovascular. Arquivos Brasileiros de Cardiologia, v. 78 , n. 5, may, 2002.

LOYOLA, M. A. Sexualidade e medicina: a revolução do século XX. Cadernos de Saúde Pública, v. 19, n. 4, jul./ago. 2003.

LUZ, A. M. H. Mulher adolescente: sexualidade, gravidez e maternidade. Porto Alegre: EDIPUCRS, 1999. 234p.

LYRA, D. G. P.; JESUS, M. C. P. Compreendendo a vivência da sexualidade do idoso. Revista Nursing, v. 104, n. 9, jan., 2007.

MACEDO, A.; NAKASATO, M.; ÁVILA, A. L. V. E.; ISOSAKI, M. Consumo de gorduras e fibras alimentares por cardiopatas com excesso de peso utilizando o questionário de freqüência alimentar simplificado. Revista Sociedade de Cardiologia do Estado São Paulo, v. 13, n. 2, p. 14-21, mar./abr. 2003.

MAIA, C. O.; GOLDMEIER, S.; MORAES, M. A.; BOAZ, M. R. Fatores de risco para a doença arterial coronariana nos trabalhadores de enfermagem. Acta Paulista de Enfermagem., v. 20, n. 2, abr/jun. 2007.

MALACRIDA, R.; GENONE, M.; MAGGIONI, A. P.; SPATARO, V.; PARISH, S.; PALMER, A.; COLLINS, R.; MOCCETTI, T. A comparison oh the early outcome of acute myocardial infarction in women and men. The New England Journal of Medicine, v. 33B, p. $8-14,1998$. 
MANCILHA-CARVALHO, J. J. Antecedentes da doença coronária: os fatores de risco. Arquivos Brasileiros de Cardiologia, v. 58, n. 4, p. 263-267, 1992.

MANFROI, W. C.; ZAGO, A. J.; LEITÃO, C. B.; ORDOVÁS, K. G.; RIBEIRO, L. W.; SOUZA, J.; KIRSCHNICK, L.; CANDIAGO, R. H.; CRUZ, R.; GOELLNER, A.; DIAS, I. Comparação da aterosclerose coronária em pacientes com infarto do miocárdio e angina do peito. Arquivos Brasileiros de Cardiologia, v. 71, n. 1, p. 25-29, jul. 1998.

MANO, R. Manuais de cardiologia: anamnese cardiológica - a dor torácica. Livro Virtual, ano 8., 2004. Disponível em: http:// manuais de cardiologia.med.br. Acesso em 25 de agosto de 2007.

MARAFON, L. P.; CRUZ, I. B. M.; SChWANKE, C. H. A.; AUGUSTIN, C. H. Preditores cardiovasculares da mortalidade em idosos longevos. Cadernos de Saúde Pública, Rio de Janeiro, v. 19, n. 3, junho. 2003.

MARCOPITO, L. F.; RODRIGUES, S. S. F.; PACHECO, M. A.; SHIRASSU, M. M.; GOLDFEDER, A. J.; MORAES, M .A. Prevalência de alguns fatores de risco para doenças crônicas na cidade de São Paulo. Revista de Saúde Pública, v. 39, n. 5, out., 2005.

MARIA, V. L;. MODENA, E. M. S. C. Atividade sexual e paciente pós infartado. Enfermagem Moderna, v. 2, n. 2, p. 22-8, 1984.

MARON, B. J. The paradox of exercise. New England Journal of Medicine, v. 343, p. 1409-1411, 2000.

MARQUES ESPINO, Y.; ESCALONA ROBAINA, C.; FLORAT GARCIA, G.; OSORIO GOMEZ, C. M.; MONTESINO del CASTILHO, M. G. Morbimortalidade por infarto agudo del miocárdio: estudo de um ano. Revista Médica Eletronica, v. 28, n. 2, mar./abr., 2006.

MARTINEZ, T. L. R. Obesidade e coração. Revista da Sociedade de Cardiologia do Estado de São Paulo, v. 6, n. 4, julho-agosto. 1996. p. 447-451. 1996.

MARTINS, D. L. Perfil diagnóstico de enfermagem de pacientes acometidos por infarto agudo do miocárdio à luz do modelo de Florence Nightingale. 115 p. Dissertação - Universidade Federal da Paraíba - Centro de Ciências da Saúde, João Pessoa, 2004.

MATTHEWS, K. A.; METILAHN, E.; KULLER, L. H. Menopause and risk factor for coronary heart disease. The New England Journal of Medicine, v. 321, p. 641 - 646, 1989.

McPERSON, C. P.; SWENSON, K. K.; PINE, D. A.; LEIMER, L. A nursing-based pilot program to reduce cardiovascular risk factors in a primary care setting. American Journal of Management Care, v. 8, n. 6, p. 543-555, 2002. 
MELO, A. S. Validação dos diagnósticos de enfermagem disfunção sexual e padrões de sexualidade ineficazes. 197 p. Tese (Doutorado) Escola de Enfermagem de Ribeirão Preto da Universidade de São Paulo. Ribeirão Preto, 2004.

MILLER, R. M. Deep breathing relaxion. AORN Journal of Denver, v. 45, n. 2, p. 484488, 1987.

MILLER, S. L.; REBER, R. J.; CHAPMAN NOVAKOFSKI, K. Prevalence of CVD risk factors and impact of a two year education program for premenopausal women. Womens Health Issues, v. 11, n. 6, p. 486-493, 2001.

MINAYO, M. C. S. (Org.) Pesquisa social: teoria, método e criatividade. 11. ed. Petrópolis: Vozes, 1996. 79 p.

MITTLEMAN, M. A.; MACLURE, M.; TOFLER, B. H.; SHERWWOD, J. B.; GOLDBERG, R. J.; MULLER, J. E. For the determinants of myocardial infarction onset study insvestigators. Triggering of acute myocardial infarction by heavy physical exertion: protection against triggering by regular exertion. The New England Journal of Medicine, v. 329, p. 1677-1683, 1995.

MOLASSIOTIS, A.; MORRIS, P. J. The meanings of qualify of life and the effects ofunrelated donor bone morrow transplans for chronic myeloid leukemia in adult-long termsurvivors. Cancer Nursing, New York, v. 21, n. 3, p. 205 - 211, 1998.

MORAES, C. R.; RODRIGUES, J. V.; TENÓRIO, E.; GOMES, C.; MARINUCCI, L.; BOUWMANN, R.; COELHO, C. T.; TEMPORAL, M. L.; BRITO, G.; TEMPORAL, S.; TORRES, J. A.; CAVALCANTI, I. L. Influência da idade na morbidade e mortalidade da cirurgia arterial coronária. Arquivos Brasileiros de Cardiologia, v. 53, n. 3, p. 161-163, set. 1989.

MORAES, I. H. S.; SANTOS, S. R. F. R. Informações em saúde: os desafios continuam. Ciências \& Saúde Coletiva, v. III, n. 1, p. 37-51, 1998.

MORALES CALATAYUD, F. El stress psicológico en el riesgo de enfermar: su atención, en el nível primário. Revista Cubana de Medicina Geral Integral, v. 7, n. 1, p. 27-47, ene./mar. 1991.

MOREIRA JR, E. D.; LOBO, C. F. L.; VILLA, M.; NICOLOSI, A.; GLASSER, D. B. A cross-sectional population-based study of erectile dysfunction epidemiology in northeastein Brazil. Program and abstracts of the American Urological Association 95th Annual Meeting: Atlanta, Georgia, Abstract 65, abr./may., 2000.

MORIGUCHI, E. H.; VIEIRA, J. L. C. Conceito de fatores de risco: hierarquia dos principais fatores de risco e susceptibilidade individual para diferentes cardiopatias. In: GIANNINI, S. D.; FORTI, N.; DIAMENT, J. Cardiopatia preventiva: prevenção primária e secundária. São Paulo: Atheneu, 2000. p. 27-41. 
MOTT, L. Teoria antropológica e sexualidade humana. 2005. Disponível em: http://www.antropologia.ufba.br . Acessado em 21 de fevereiro de 2005.

MOTTA, K. A. M. B.; MUNARI, D. B.; LEAL, M. L.; MEDEIROS, M.; NUNES, F. C. As trilhas essenciais que fundamentam o processo e desenvolvimento da dinâmica grupal. Revista Eletrônica de Enfermagem, v. 9, n. 1, p. 229-241, 2007. Disponível em: http://www.fen.ufg.br/revista/v9/n1/v9n1a18.htm. Acessado em 15 de novembro de 2007.

MÜLLER, A. Sexualidade. 1999. Disponível em: http://spacnet.com.br Acessado em 1911-2005.

MÜLLER-NORDHORN, J.; WILLICH, S. N. Cardiovascular risk in sports. Bundesgesuordtheitsblatt Gesundheitsforschung Gesundheitsschutz, v. 48, n. 8, p. 922 926, aug., 2005.

MUNARI, D. B.; CARDOSO, E. E.; MEDEIROS, M. A utilização do grupo como estratégia em pesquisa. In: $11^{\circ}$ Seminário Nacional de Pesquisa em Enfermagem, 2001, Belém-PA. Anais do $11^{\circ}$ Seminário Nacional de Pesquisa em Enfermagem, 2001. p. 1-1.

MUNARI, D. B.; FUREGATO, A. R. Enfermagem e Grupos. Goiânia: Ed. AB, 2003. 92 p.

MURTA, A. A.; MARQUETTI, P. R. C.; IOURES, D.; ROCHA, R. Endocardite infecciosa: o grau de informação do paciente com prótese valvar. Rev. méd Paraná, v. 54, n. 3/4, p. 19-22, jul-dez, 1997.

NEVES, J. L. Pesquisa qualitative: características, usos e possibilidades. Cadernos de Pesquisas em Administração, São Paulo, v. 1, n. 3, 2ºm., 1996.

NETO, J. R. F.; CHAGAS, A. C. P.; LUZ, P. L. Síndromes coronárias: avanços na fisiopatologia. Revista Sociedade de Cardiologia do Estado São Paulo, v. 9, n. 1, jan./fev. 1999.

OLIVEIRA, G. L. M.; KLEIN, C. H.; SOUZA; SILVA, N. A. Mortalidade por doenças isquêmicas do coração, doenças cerebrovasculares e causas mal definidas nas regiões de saúde do estado do Rio de Janeiro, no período de 1980 a 2000. Revista SOCERJ, v. 13, n. 01, p. $13-22$, jan./fev. 2005.

OOIJEN, E. V. How illness may affect patients sexuality. Nursing Times, v. 91, n. 23, p.36-37, 1995.

ORGANIZAÇÃO MUNDIAL DA SAÚDE. Conceitos para Saúde Sexual. Organização Mundial de Saúde (OMS). Brasília, 1986.

ORGANIZAÇÂO MUNDIAL DA SAÚDE. Cuidados Inovadores para Condições Crônicas: componentes estruturais de ação. Relatório mundial/ Organização Mundial de Saúde (OMS). Brasília, 2003. 
ORGANIZAÇÃO PAN-AMERICANA DE SAÚDE. Doenças crônico-degenerativas e obesidade: estratégia mundial sobre alimentação saudável, atividade física e saúde. In: Organização Pan-Americana de Saúde. Brasília, 2003. p. 7-56.

ORNISH, D.; BROWN, S. E.; SCHERWITZ, L. W. Can lifestyle changes reverse coronary heart disease? The lifestyle heart trial. Lancet, v. 336, n. 21, p. 129-133, 1990.

PAPADOPOULOS, C. Cardiovascular drugs and sexuality. Archives Internalls of Medicine, v. 2, p. 1341-1345, 1980.

PAPADOPOULOS, C.; SHELLEY, S. I.; PICCOLO, M.; BEAMONT, C.; BARNETT, L. Sexual activity after coronary bypass surgery. Chest, v. 90, n. 5, p. 681-685, 1986.

PAPALÉO NETO, M. Gerontologia. São Paulo: Atheneu, 1996.

PASSADOR, M. B. A sexualidade e o profissional de enfermagem. Revista Academia de Enfermagem, v. 2, n. 2, p. 30-33, 2004.

PASSOS, L. C. S.; LOPES, A. A.; COSTA, V.; LOBO, N.; RABELO JÚNIOR, A. Difference in the in-hospital mortality of unstable angina pectoris between men an women. Arquivos Brasileiros de Cardiologia, v. 72, n. 6, p. 673 - 676, 1999.

PELÁ, N. T. R.; GIR, E.; NOGUEIRA, M. S. Sexualidade humana na formação do enfermeiro. Revista Latino-americana de Enfermagem março-abril; v. 8, n. 2, p.33-40, 2000 .

PELÁ, N. T. R.; MELO, A. S.; SANTANA, V. M. S.; NHAMBA, A. L. A sexualidade humana no contexto da assistência de enfermagem. Revista Brasileira de Sexualidade Humana, São Paulo, v.6, n.1, p. 99-113, jan. 1995.

PEREIRA, A. L. F. As tendências pedagógicas e a prática educativa nas ciências da saúde. Cadernos de Saúde Pública, Rio de Janeiro, v. 19, n. 5, p. 1527-1534, set-out, 2003.

PEREIRA, A. P.; OliveirA, A. F. C.; FERnANDES, A. C. C. S; PELÁ, N. T. R.; MORIYA, T. M. Vivenciando situações constrangedoras: o enfermeiro frente à sexualidade em seu exercício profissional. $71 \mathrm{f}$. Monografia (Enfermagem) - Curso de Enfermagem do Centro Universitário Barão de Mauá, Centro Universitário Barão de Mauá, Ribeirão Preto, 2000.

PESSUTO, J.; CARVALHO, E. C. de. Fatores de risco em indivíduos com hipertensão arterial. Revista Latino-americana de Enfermagem, v. 6, n. 1, p. 33-39, jan., 1998.

PIMENTA, C. A. M. Alívio da dor: experiências de enfermagem na utilização de práticas não farmacológicas. Revista Paulista de Enfermagem. São Paulo, v. 9, n. 2, p. 73-77, 1990. 
PINTON, F. A.; CARVALHO, C. F.; MIYAZAKI, M. C. O. S.; GODOY, M. F. Depressão como fator de risco de morbidade imediata e tardia pós-revascularização cirúrgica do miocárdio. Brazilian Journal of Cardiovascular Surgery, v. 21, n. 1, p. 68-74, jan-mar, 2006.

POLANCZYK, C. A. Decisão clínica em hipertensão arterial sistêmica baseada em análises econômicas. Revista Brasileira de Hipertensão, v. 9, n. 1, p. 29-34, janeiro-março. 2002.

POLIT, D.; HUNGLER, B. Pesquisa e análise qualitativa. In: pesquisa em Enfermagem. Porto Alegre: Artes Médicas, 1995. p. 269-288.

PYERITZ, R. E. Genética e doença cardiovascular. In: BRAUNWALD, E. Tratado de Medicina Cardiovascular. São Paulo: ROCA, 5. ed., 1999, p.1767.

QUAIOTI, T. C. B.; ALMEIDA, S. S. Determinantes psicobiológicos do comportamento alimentar: uma ênfase em fatores ambientais que contribuem para a obesidade. Psicologia USP, v. 17, n.4, p.193-211, 2006.

QUEIROZ, M. I. P. Variações sobre a técnica de gravador no registro da informação viva. São Paulo, Faculdade de Filosofia, Letras e Ciências Humanas/USP, 1983. Textos, n. 4.

RACHID, M. Avaliação pré-participação. Revista SOCERJ, v. 13, n. 4, 2000.

RIBEIRO, A. L. P. Estratégias diagnósticas na angina de peito. Revista Médica de Minas Gerais, v. 10, n. 1, p. 22-7, jan./mar. 2000.

RIBEIRO, E. M. P. C. O paciente terminal e a família. In: CARVALHO, M. M. M. J. Introdução à psicologia: Ed Psy II, 1994.

RIBEIRO, J. C. Levantamento dos fatores de risco para o infarto agudo do miocárdio em comunidades brasileiras. $90 \mathrm{f}$. Monografia (Enfermagem)-Curso de Enfermagem da Universidade de Ribeirão Preto, Universidade de Ribeirão Preto-UNAERP, Ribeirão Preto, 2005.

REBELLO, L. E. F. S. Iniciação sexual e masculinidade: uma análise das narrativas de homens jovens. 76p. Dissertação (Mestrado) - Instituto Fernandes Figueira, Rio de Janeiro, 2006.

ROCHA, K. P. W. F. A educação em saúde no ambiente hospitalar. Revista Nursing, v. 108, n. 9, p. 216-221, 2007.

RODRIGUES, R. A. P.; CASAGRANDE, L. D. R. Atividade educativa com as idosas que tiveram queda e seus cuidadores: atuação da enfermagem geriátrica no domicílio. Acta Paulista de Enfermagem, São Paulo, v. 9, n. 1, jan-abr. 1996.

RODRÍGUEZ PERÓN, J. M.; MORA, S. R.; ACOSTA CABRERA, E.; MENENDEZ LÓPEZ, J. R. Repercusion negativa del tabaguismo em la evolución clínica de la 
enfermedad cardiovascular aterosclerótica. Revista Cubana de Medicina, v. 33, n. 2, abr./jun., 2004.

ROMANELLI, G. A entrevista antropológica, troca e alteridade. In: ROMANELLI, G.; BIASOLI-ALVES, Z. M. Diálogos metodológicos sobre prática da pesquisa. Ribeirão Preto: Legis Summa, 1998, cap. 6, p. 119-33.

ROMANO, B. W.; HOJAIJ, E. M.; FAVARATO, M. E. C. S.; LEONARD, A.I.; ALEM, S. A.; PIRES, C.A. Sexualidade e cardiopatia: um tabu a ser enfrentado. Revista Sociedade de Cardiologia do Estado São Paulo, v. 8, n. 5, p. 1-8, set./out. 1998. Suplemento A.

ROUX, A. V. D.; MERKIN, S. S.; ARNETT, D.; CHAMBLESS, L.; MASSING, M.;D.; JAVIER NIETO, F.; SORLIE, P.; SZKLO, M.; TYROLER, H. A.; WATSON, R. L. Neighborhood of residence and incidence of coronary heart disease. The New England Journal of Medicine, n. 345, p. 99-106, 2001.

RUFFTER, M. A. On arterial lesions founds in Egyptian mummiis (1580 BC-525 AD). The Journal of Pathology and Bacteriology, v. 15, p. 453-462, 1911.

SAITO, M. I. Sexualidade, adolescência e orientação sexual: reflexões e desafios. Revista Médica (São Paulo), São Paulo, v. 75, n. 1, p. 26-30, jan. 1996.

SANER, H. Stress as a cardiovascular risk factor. The Umsch, v. 62, n. 9, p. $597-602$, sep., 2005.

SANTOS, E. K. A. Comparação entre as teorias de enfermagem de Horta, King, Rogers, Roy e Orem. Revista Paulista de Enfermagem, São Paulo, v. 5, n. 1, p. 3-7, jan./mar., 1985.

SANTOS, J. E. Perda de peso (mesmo que aparentemente modesta) e exercício físico: duas armas poderosas na redução de fatores de risco para a doença arterial coronariana. Arquivos Brasileiros de Cardiologia, v. 87, n. 1, p. 1-2, jun., 2006.

SAYÃO, R. Saber e sexo? Os problemas da informação sexual e o papel da escola. In: AQUINO, J. G. (org.) Sexualidade na escola: Alternativas teóricas e práticas. São Paulo, Perspectiva, 1995.

SCHLEIFER, S. J.; MACARI-HINSON, M. M.; COYLE, D. A.; SLATER, W. R.; KAHN, M.; GORLIN, R.; ZUCKER, H. D. The nature and course of depression following myocardial infarction. Archives of International Medicine, v. 49, n. 8, p. 1785-1789, 1989.

SCHRAIBER, L. B. Pesquisa qualitativa em saúde: reflexões metodológicas do relato oral e produção de narrativas em estudo sobre a profissão médica. Revista de Saúde Pública, São Paulo, v. 29, n. 1, fev. 1995. 
SEGRE, M.; FERRAZ, F. C. O conceito de saúde. Revista de Saúde Pública, v. 31, n. 5, out.1997.

SERRA, S. M. Espasmo coronariano desencadeado pelo exercício dinâmico. Revista Sociedade de Cardiologia do Estado do Rio de Janeiro, v. 13, supl. A, 2000.

SILVA, A. L. A. C.; MUNARI, D. B.; LIMA, F. V.; SILVA, W. O. Atividades grupais em saúde coletiva: características, possibilidades e limites. Revista de Enfermagem da UERJ, v. 11, n. 1, p. 18-24, 2003.

SILVA, L. H. F.; NASCIMENTO C. S.; VIOTTI JR., L. A. P. Revascularização do miocárdio em idosos. Revista Brasileira de Cirurgia Cardiovascular, v. 12, n. 2, p. 132 140, abr./jun., 1997.

SILVA, L. M. V.; PAIM, J. S.; COSTA, M. C. N. Desigualdades na mortalidade, espaço estratos sociais. Revista de Saúde Pública, v. 33, p. 187-197, 1999.

SILVA, N. A. S. Saúde cardiovascular na era tecnológica. Arquivos Brasileiros de Cardiologia, v.83, n. 6, dezembro. 2004.

SILVA, S. S. Angina pectoris instável: perfil de clientes de uma instituição privada. 102 p. Dissertação (Mestrado) Escola de Enfermagem de Ribeirão Preto da Universidade de São Paulo, Ribeirão Preto, 2003.

SIMÃO, M. Fatores de risco para as doenças cardiovasculares em trabalhadores de uma destilaria do interior paulista. 88f. Dissertação (Mestrado) - Escola de Enfermagem de Ribeirão Preto/USP. Ribeirão Preto, 2001.

SIQUEIRA, F. P. C. Estilo de vida e hipertensão.183f. Dissertação (Mestrado) - Escola de Enfermagem de Ribeirão Preto/USP. Ribeirão Preto, 2002a.

SIQUEIRA, M. E. C. Teorias sociológicas do envelhecimento. In: FREITAS, E. V.; PY, L.; NERI, A. L.; CANÇADO, F. A. X.; GORZONI, M. L.; ROCHA, M. S. M. (orgs.). Tratado de Geriatria e Gerontologia. Rio de Janeiro, R. J.: Guanabara Koogan, 2002b.

SIVIERO, I. M. P. S.; SCATENA, M. C. M.; COSTA JUNIOR, M. L. Fatores de risco numa população de infartados. Revista de Enfermagem UERJ, v. 13, n. 3, p. 319 - 324, set./dez., 2005.

SMANIO, P.; MASTROCOLLA, L. E. Atividade física e doença cardiovascular na mulher. Revista Sociedade de Cardiologia do Estado de São Paulo, v. 2, 184-192, mar-abr., 2005.

SMELTZER, S. C.; BARE, B. G. Tratado de Enfermagem medico cirúrgica. 7. ed. Rio de Janeiro: Guanabara Koogan, v. 2, cap. 27, p. 527-573. 1994. 
SMITH, E. R.; CATULO, E. J.; DONHVE, J. P. The inibitory effects of propanolol on genital reflexes in male rats. Pharmacology Biochemistry and Behavior, v. 52, p. 541$546,1995$.

SOARES, A. L. M.; MOREIRA, V. Ser cardiopata: uma condição estigmatizante que causa sofrimento psíquico. In: II Congresso Internacional de Psicopatologia Fundamental e VII Congresso Brasileiro de Psicopatologia Fundamental. Belém. Associação Universitária de Pesquisa em Psicopatologia Fundamental, 2006.

SOCIEDADE BRASILEIRA DE CARDIOLOGIA. Diretrizes da Sociedade Brasileira de Cardiologia sobre angina instável e infarto agudo do miocárdio sem supradesnível ST. Arquivos Brasileiros de Cardiologia, v. 77, p. 1-22, 2001. Suplemento 2.

SOCIEDADE BRASILEIRA DE HIPERTENSÃO. IV Diretrizes Brasileiras de Hipertensão Arterial. Campos do Jordão, 2002.

SOTO, S.; JUAN, R.; MIGUEL BAÑADOS, C. Cardiopatia coronária em la mujer. Bulletin of the Hospital San Juan de Dios, v. 45, n. 2, p. 85-91, mar/abr., 1998.

STAMLER, J. Epidemiology established major risk factors, and the primary prevention of coronary heart disease. In: CHATERJEE, K. Cardiology: an illustrated text / reference, v. 2. Philadelphia: J. B. Lippincott, 1991.

STEFFENINO, G.; GALLIASSO, M.; GASTALDI, C.; RICCA, N.; MANGIACOTTI, B. Nurses observation study on the practice of secondary prevention in a cardiovascular department. Italian Heart Journal, v. 4, n. 7, p. 473-478, 2003.

STOCCO, R.; BARRETO, A. C. P. Influência de fatores ambientais na gênese e evolução das cardiopatias. In: GIANNI, S. D. Cardiopatia preventiva. São Paulo: Atheneu, 2000. p. 51-56, cap. 5.

SUEDEKUM, E. W. M.; CASSOL, M. J.; MARTINO, M. M. F. Assistência de enfermagem na reabilitação cardíaca de pacientes infartados. Revista Paulista de Enfermagem, v.14, n. 1, p. 29-35, 1995.

TAVARES, A. Impacto da hipertensão arterial no Brasil: aspectos epidemiológicos e dados sobre o tratamento. Arquivos Brasileiros de Cardiologia, v. 3, n. 2, p. 38-47, julhoagosto, 2001.

TAYLOR, T. A pré-história do sexo: Quatro milhões de anos de cultura sexual. Rio de Janeiro, Campos, 1997.

THIOLLENT, M. Metodologia da pesquisa-ação. 2. ed. São Paulo: Cortez, 1992. 107p.

TIMERMAN, A.; CARDOSO, L. F.; PAIVA, E. Projeto Emerge Brasil: Síndromes Coronárias Agudas. S. 1.: Aventis, 2003. 
TIMERMAN, R. S.; SOUZA, M. F. M.; SERRANO JR, C. V. Aspectos epidemiológicos das doenças cardiovasculares em nosso meio: tendência da mortalidade por doença isquêmica do coração no Brasil de 1979 a 1996. Revista Sociedade de Cardiologia do Estado São Paulo, v. 11, n. 4, p. 715-223, jul./ago. 2001.

THÉROUX, P. Unstable angina. In: ALEXANDER, R. W.; SCHLANT, R. C.; FURST, V.; ROBERT, R. (Eds.) Hurst's the health. N.Y. Mcgraw-HL, p. 153-159, 1999.

TRIVIÑOS, A. N. S.; KOPS, D. A. A revisão da literatura nas teses de mestrado: prospectiva. Revista de Orientação Educacional, Porto Alegre, v. 1, n. 9, p. 46-51, out. 1991.

UENO, M. The so-called coition death. The Japanese Journal of Legal Medicine, v. 17, p. 330-340, 1963.

UNIVERSIDADE DE SÃO PAULO. Escola de Enfermagem de Ribeirão Preto. Comitê de Ética em Pesquisa da Escola de Enfermagem de Ribeirão Preto. Diretrizes e normas regulamentadoras de pesquisa envolvendo seres humanos. Ribeirão Preto: EERP, 1999. $44 \mathrm{p}$.

VALE, A. A. L.; MARTINEZ, T. L R. Fatores de risco coronário: quais os já consagrados e sua importância na gênese da doença coronária? In: TIMERMAN, A.; CESAR, L.A.M. Manual de cardiologia do Estado de São Paulo/SOCESP. São Paulo: Atheneu, 2000. Cap.20, p.99-102.

VALE, A. A. L.; MARTINEZ, T. L. R. Prevenção: importância e estratificação de risco. Atheros, v. 12, n. 1, p. 7-12. 2001.

VERAS, R. P. País de jovens de cabelos brancos. Rio de Janeiro: Relume Dumara/UERJ, 1994, 224p.

VIOLANTE, M. L. V. A psicossexualidade. Psicanálise e Universidade, v. 18, p. 43-52, abr., 2003.

VITIELLO, N. Reprodução e sexualidade: um manual para educadores. São Paulo, CEICH, 1994. p. 5-15.

VITIELLO, N. Aspectos sistêmicos da sexualidade. In: VITIELLO, N. Sexologia II. São Paulo: Rocca, 1996. p. 21-26.

VOGELS, E. A ; LAGRO-JANSSEN, A. L. M.; VAN WELL, C. Sex differences in cardiovascular disease: are women with low socioeconomic status at high risk? British Journal of General Pratice, v. 46, p. 963-966, 1999.

ZAITUNE, M. P. A.; BARROS, M. B. A.; CESAR, C. L. G.; CARANDINA, L.; GOLDBAUM, M. Fatores associados ao sedentarismo no lazer em idosos, Campinas, São Paulo, Brasil. Cadernos de Saúde Pública, v. 23, n. 6, p. 1329 -1338, jun., 2007. 
ZALAR, M. K. Role preparation for nurses in human sexual functioning. Nursing Clinical Norte American. Philadelphia, v. 17, n. 3, p.351-363, Sep. 1982.

ZILLI, E. C. Manuseio da disfunção sexual nos cardiopatas - recomendações atuais. Revista SOCERJ, v. 13, n. 3, jul./ago./set., 2000.

WEBB, C. Sexuality, Nursing and Health. Great Britain, John Willey, 1985. p. 3-6.

WEI, M.; MACERA, C. A.; DAVIS, D. R.; HORNUNG, C. A.; NANKIN, H. A.; BLAIR, S. N. Total cholesterol and high density lipoprotein cholesterol as important prediction of erectile dysfunction. American Journal of Epidemiology, v. 140, p. 930-937, 1994. 
etpendices 


\section{APÊNDICE A \\ QUESTIONÁRIO INFORMATIVO}

$\operatorname{Sr}(\mathrm{a})$

, este questionário é muito

importante para o nosso estudo. Sua participação tem grande significado para nós. Seu nome será mantido em sigilo. Agradecemos sua valiosa contribuição.

\section{I - DADOS DE IDENTIFICAÇÃO}

Código do cliente:

Sexo: ( )M ( )F

Idade: anos

Escolaridade:

Religião:

Estado civil:

\section{II - QUESTÕES SOBRE O TEMA CENTRAL}

1-Qual o significado da sua vida? Coisas boas e ruins.

2-O que você pensa sobre o seu problema no coração?

3-O que você acredita que levou a esse problema?

4-Quais as maiores dificuldades que você tem hoje em relação ao problema no coração?

5-O que você entende por sexualidade?

6 - O que você entende por sexo?

7-Como era sua vida sexual antes da doença?

8-Como é sua vida sexual agora?

9-Como era o relacionamento com o(a) parceiro(a) antes do problema no coração?

10-Como está sua relação com a família hoje?

11-Espaço livre para falar o que quiser. 


\section{III - DADOS RELACIONADOS AO ESTILO DE VIDA}

1 - Quais dessas situações estão presentes na vida do (a) Sr. (a) e que acredita ter relação com o seu problema no coração?

( ) dieta incorreta

( ) falta de exercícios físicos

( ) tabagismo (uso de cigarros)

( ) ingestão excessiva de álcool

( ) estresse

( ) uso de estrógenos (hormônio)

( ) idade

( ) raça

( ) história familiar

( ) diabetes

( ) hipercolesterolemia (colesterol aumentado)

( ) hipertensão arterial (pressão alta)

( ) obesidade

( ) outros.

Especificar:

2 - Diagnóstico principal: 


\section{APÊNDICE B}

Ilmo Sr.

Antonio José Fabbri

Prefeito Municipal de Brodowski

Solicito junto a Vossa Senhoria a autorização para realizar um levantamento junto aos livros de registros de encaminhamentos de contra-referências de clientes para a especialidade de cardiologia neste município, com a finalidade de obter a identificação e o número de clientes com diagnóstico de doença arterial coronariana, em seguimento ambulatorial, em Brodowski. Dados como nomes de clientes e diagnósticos darão subsídios para contactá-los, a partir da autorização para consulta de seus endereços. Os achados servirão à investigação proposta para o desenvolvimento de minha tese de Doutorado, na Escola de Enfermagem de Ribeirão Preto da Universidade de São Paulo.

O objetivo do estudo é levantar quais as dificuldades do(a) cliente em relação às causas para as doenças do coração e conflitos em sua sexualidade.

Diante da importância reservada às questões de pesquisa neste município, reitero tal solicitação me comprometendo a cumprir todas as questões éticas envolvidas na ação e resultados.

Atenciosamente, 


\section{APÊNDICE C}

Ilma $\mathrm{Sr}^{\mathrm{a}}$

\section{Eunice Lorencini}

\section{Secretária da Saúde do município de Brodowski}

Solicito junto a Vossa Senhoria a autorização para realizar um levantamento junto aos livros de registros de encaminhamentos de contra-referências de clientes para a especialidade de cardiologia neste município, com a finalidade de obter a identificação e o número de clientes com diagnóstico de doença arterial coronariana, em seguimento ambulatorial, em Brodowski. Dados como nomes de clientes e diagnósticos darão subsídios para contactá-los, a partir da autorização para consulta de seus endereços. Os achados servirão à investigação proposta para o desenvolvimento de minha tese de Doutorado, na Escola de Enfermagem de Ribeirão Preto da Universidade de São Paulo.

O objetivo do estudo é levantar quais as dificuldades do(a) cliente em relação às causas para as doenças do coração e conflitos em sua sexualidade.

Diante da importância reservada às questões de pesquisa neste município, reitero tal solicitação me comprometendo a cumprir todas as questões éticas envolvidas na ação e resultados.

Atenciosamente, 


\section{APÊNDICE D}

Ilma Sra.

Prof $^{\text {a }}$ Dra Luciana Rezende Alves Oliveira

Coordenadora do Comitê de Ética em Pesquisa da UNAERP

Universidade de Ribeirão Preto - Campus Ribeirão Preto

Venho pelo presente encaminhar o Projeto intitulado: RESGATANDO CONFLITOS RELATIVOS À SEXUALIDADE DOS CLIENTES PORTADORES DE CORONARIOPATIAS; a ser desenvolvido por Silvia Sidnéia da Silva, do Programa de PósGraduação-Área de Enfermagem Psiquiátrica e Ciências Humanas da Escola de Enfermagem de Ribeirão Preto da Universidade de São Paulo, para apreciação deste Comitê.

Atenciosamente,

$\overline{\text { Prof }^{a} \operatorname{Dr}^{a} \text { Sonia Maria V. Bueno - Orientadora }}$

$\overline{\text { Ś́lvia Sidnéia da Silva - Pesquisadora }}$

Ribeirão Preto, 15 de setembro de 2006. 


\section{APÊNDICE E}

\section{TERMO DE CONSENTIMENTO LIVRE E ESCLARECIDO}

Estamos realizando um estudo intitulado: RESGATANDO CONFLITOS RELATIVOS À SEXUALIDADE DOS CLIENTES PORTADORES DE CORONARIOPATIAS, sob orientação da Prof ${ }^{a}$ Dra. Sonia Maria Villela Bueno, com o objetivo de levantar quais suas dificuldades em relação às causas para as doenças do coração e conflitos quanto à sua sexualidade. Estes dados farão parte de uma pesquisa cujos resultados serão apresentados em livros e eventos científicos.

A sua participação não envolverá despesas, riscos, e nem mesmo remuneração. A sua identidade será mantida no anonimato, bem como a da Instituição de Saúde em que é acompanhado.

Você poderá obter esclarecimentos sobre o estudo a qualquer hora que desejar, e pode inclusive deixar de participar mesmo que já tenha manifestado interesse anterior pela sua participação.

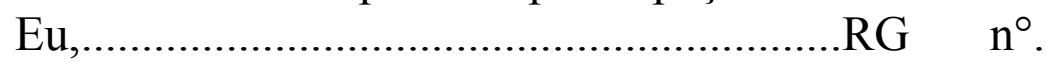
concordo em participar da pesquisa intitulada: RESGATANDO CONFLITOS RELATIVOS À SEXUALIDADE DOS CLIENTES PORTADORES DE CORONARIOPATIAS, e estou ciente que:

1-Os resultados deste estudo farão parte de uma pesquisa científica que serão apresentados em livros e eventos científicos;

2-A minha participação não envolverá remuneração e nem mesmo gastos;

3- Estou livre de qualquer risco proveniente da pesquisa;

4-A minha identidade e da Instituição de Saúde será mantida no anonimato;

5-A qualquer momento poderei entrar em contato com a pesquisadora responsável;

6-Poderei desistir a qualquer momento mesmo que minha manifestação anterior tenha sido a favor da participação.

ASSINATURA DA(O) CLIENTE

ASSINATURA DA PESQUISADORA

SILVIA SIDNÉIA DA SILVA

TELEFONE: (016)3612-7047 
eAnexo

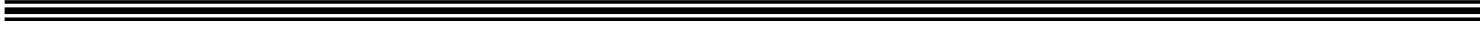




\section{ANEXO 1}

\section{UNA'ERP}

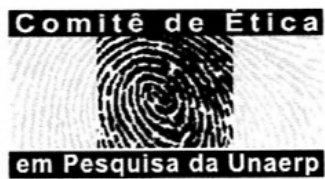

Ribeirão Preto, 04 de dezembro de 2006.

Prezada Senhora,

Vimos por meio desta informar que Comitê de Ética em Pesquisa da UNAERP Universidade de Ribeirão Preto analisou e aprovou sem restrições, o Projeto intitulado "RESGATANDo CONFlitos RELATIVOS À SEXUALIDAdE DOS CliENTES PORTADORES DE CORONARIOPATIAS", tendo como pesquisadora Prof' Silvia Sidnéia da Silva, bem como o respectivo Termo de Consentimento Livre e Esclarecido, em reunião ocorrida na data de 31 de outubro de 2006, registrado sobre o ComÉt: 080/06.

Temos ciência de que os estudos estão sendo conduzidos na Prefeitura Municipal de Brodowski.

Solicitamos que a senhora encaminhe os relatórios parciais e finais, bem como envie-nos possíveis emendas e novos termos de consentimento livre e esclarecido, notifique qualquer evento adverso sério ocorrido no centro e novas informações sobre a segurança do estudo para que possamos fazer o devido acompanhamento.

Atenciosamente,

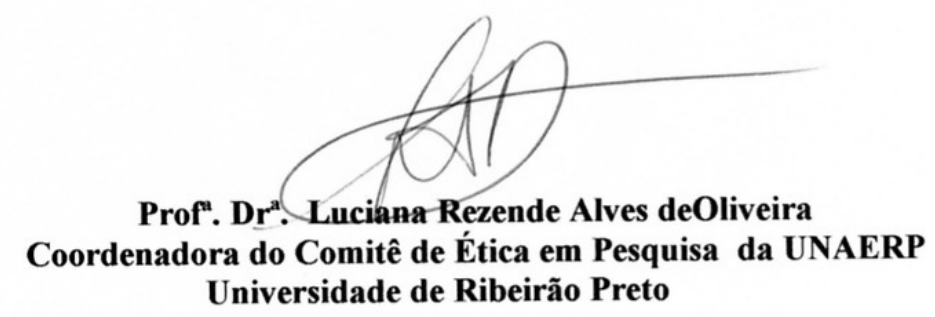

Av: Costabile Romano, 2201 - Bairro Ribeirânia - Ribeirão Preto-SP - CEP. 14096-380 Fone: (xx16) 3603-6915 - e-mail cetica $a$ unaerp.br 